\title{
FY 1994 Ambient Air Monitoring Report for McMurdo Station, Antarctica
}

R. M. Lugar

Published December 1994

\section{ERM Program Management Company 402 Shoup Ave. Idaho Falls, Idaho 83402}

\footnotetext{
Prepared for Lockheed Idaho Technologies Company Under Interagency Agreement No. DPP-9102787 with the

U.S. Department of Energy Assistant Secretary for Environmental Management Under DOE Idaho Operations Office Contract DE-AC07-94ID13223 and the National Science Foundation Office of Polar Programs Arlington, VA 22230
} 


\section{DISCLAIMER}

This report was prepared as an account of work sponsored by an agency of the United States Government. Neither the United States Government nor any agency thereof, nor any of their employees, makes any warranty, express or implied, or assumes any legal liability or responsibility for the accuracy, completeness, or usefulness of any information, apparatus, product, or process disclosed, or represents that its use would not infringe privately owned rights. Reference herein to any specific commercial product, process, or service by trade name, trademark, manufacturer, or otherwise does not necessarily constitute or imply its endorsement, recommendation, or favoring by the United States Government or any agency thereof. The views and opinions of authors expressed herein do not necessarily state or reflect those of the United States Government or any agency thereof. 


\section{DISCLAIMER}

Portions of this document may be illegible in electronic image products. Images are produced from the best available original document. 


\begin{abstract}
This report presents the results of ambient air monitoring performed during the 1994 fiscal year (FY 1994) in the vicinity of McMurdo Station, Antarctica. Routine monitoring was performed during the 1993-1994 austral summer at three locations for airborne particulate matter less than 10 micrometers (PM-10) and at two locations for carbon monoxide (CO), sulfur dioxide $\left(\mathrm{SO}_{2}\right)$, and nitrogen oxides $\left(\mathrm{NO}, \mathrm{NO}_{2}\right.$, and $\mathrm{NO}_{\mathrm{x}}$ ). Selected PM-10 filters were analyzed for arsenic, beryllium, cadmium, chromium, lead, mercury, and nickel. Additional air samples were collected at three McMurdo area locations and at Black Island for determination of the airborne concentration of polychlorinated dibenzo-p-dioxins (PCDDs) and polychlorinated dibenzofurans (PCDFs). Sampling site selection, sampling procedures, and quality assurance procedures used were consistent with U.S. Environmental Protection Agency guidance for local ambient air quality networks.
\end{abstract}




\section{EXECUTIVE SUMMARY}

PM-10 and gaseous pollutant ambient air concentrations were well below the U.S. National Ambient Air Quality Standards. Mean PM-10 levels for the 1993-1994 austral summer were lower than the previous summer, with values averaging $1.6 \mu \mathrm{g} / \mathrm{m}^{3}$ at the predominantly upwind location, $3.7 \mu \mathrm{g} / \mathrm{m}^{3}$ at a location approximately $500 \mathrm{~m}$ downwind of the station, and $9.8 \mu \mathrm{g} / \mathrm{m}^{3}$ at a "downtown" location. Seasonal average $\mathrm{CO}$ levels were near the analyzer detection limit at both monitoring locations: $0.37 \mathrm{ppm}$ at central McMurdo and $0.15 \mathrm{ppm}$ at Hut Point. Seasonal average $\mathrm{SO}_{2}$ levels at both locations were less than the 0.1 -ppb analyzer detection limit. Nitrogen oxide levels at central McMurdo were planned for measurement; however, a defective analyzer prevented collection of these data at this location. Nitrogen oxides were successfully measured at Hut Point, with seasonal averages of: $3.5 \mathrm{ppb}$ NO, $2.0 \mathrm{ppb}$ $\mathrm{NO}_{2}$, and $5.5 \mathrm{ppb} \mathrm{NO}$. Trace (sub-pg/m ${ }^{3}$ ) levels of airborne PCDD/PCDF compounds were detected only at the central McMurdo and Hut Point locations. The results from central McMurdo demonstrated the highest PCDD/PCDF concentrations and congener variety as compared to the results from Hut Point, where only the octachlorinated dioxin congener was detected. Total PCDD concentrations at central McMurdo ranged from 0.12 to $0.93 \mathrm{pg} / \mathrm{m}^{3}$, and total PCDF ranged from below detection to $0.10 \mathrm{pg} / \mathrm{m}^{3}$. The concentrations and number of congeners measured in FY 1994 were reduced from measurements performed in FY 1993, and are likely attributed to the cessation of selected solid waste incineration in March 1993. The congener types detected in FY 1994 were all previously detected in FY 1993, indicating that there are combustion sources (power plant, vehicles, heating furnaces, etc.) at McMurdo other than the waste incinerator which contribute PCDD/PCDF compounds to the ambient air. The most frequently detected congeners, found usually in the highest concentrations, were octachloro dioxin (OCDD) and heptachlorodioxin (HPCDD). Results from remote Black Island and a predominantly upwind site confirmed that the background Antarctic air does not contain measurable PCDD/PCDF compounds.

The FY 1994 season of ambient air monitoring at McMurdo resulted in a larger and more reliable set of ambient air data. These data are useful for assessing the impact of McMurdo operations on local air quality, and will aid in future evaluation of the impact of changes in station population, fuel consumption, and station operations on air quality. 


\section{CONTENTS}

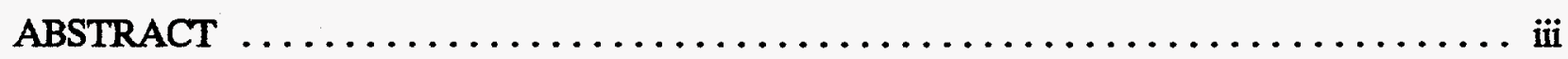

EXECUTIVE SUMMARY $\ldots \ldots \ldots \ldots \ldots \ldots \ldots \ldots \ldots \ldots \ldots \ldots \ldots \ldots \ldots \ldots \ldots \ldots$

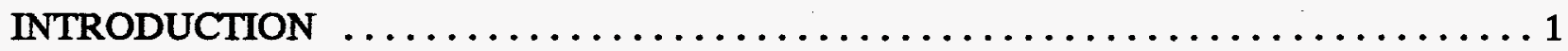

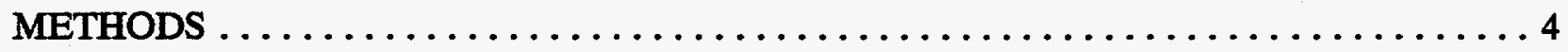

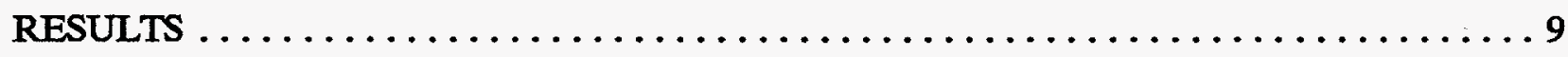

CONCLUSIONS $\ldots \ldots \ldots \ldots \ldots \ldots \ldots \ldots \ldots \ldots \ldots \ldots \ldots \ldots \ldots \ldots \ldots \ldots \ldots \ldots \ldots \ldots$

REFERENCES $\ldots \ldots \ldots \ldots \ldots \ldots \ldots \ldots \ldots \ldots \ldots \ldots \ldots \ldots \ldots \ldots \ldots \ldots \ldots \ldots \ldots \ldots \ldots$

Appendix A-1993-1994 Austral Summer Hourly Average $\mathrm{CO}, \mathrm{SO}_{2}$, and $\mathrm{NO}_{\mathrm{x}}$ concentrations at Hut Point and Central McMurdo, Antarctica $\ldots \ldots \ldots \ldots \ldots \ldots \ldots \ldots \ldots \ldots \ldots \ldots \ldots \ldots . . .1$

\section{FIGURES}

1. Map of ambient air monitoring stations at McMurdo, Antarctica $\ldots \ldots \ldots \ldots \ldots \ldots$

2. PM-10 levels at three sites near McMurdo, Antarctica during the 1992-1993 austral summer

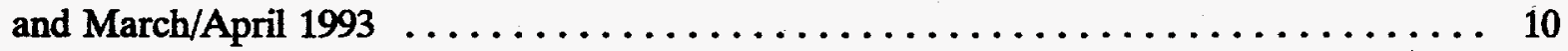

3. PM-10 levels at three sites near McMurdo, Antarctica during the 1993-1994 austral summet1

4. PM-10 metals concentrations at 8 -Site $\ldots \ldots \ldots \ldots \ldots \ldots \ldots \ldots \ldots \ldots \ldots \ldots \ldots \ldots$

5. PM-10 metals concentrations at Central McMurdo $\ldots \ldots \ldots \ldots \ldots \ldots \ldots \ldots \ldots$

6. PM-10 metals concentrations at Hut Point $\ldots \ldots \ldots \ldots \ldots \ldots \ldots \ldots \ldots \ldots \ldots \ldots \ldots \ldots \ldots \ldots$

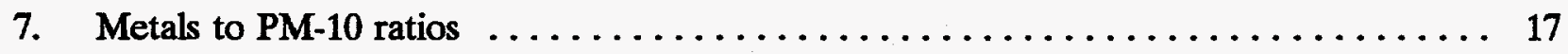

8. Profile of PCDD/PCDF congeners detected during 1993-1994 austral summer at central McMurdo, Antarctica ............................... 26

9. Profile of PCDD/PCDF congeners detected during 1993-1994 austral summer at Hut Point, Antarctica

10. PCDD/PCDF concentration (expressed as 2, 3, 7, 8-TCDD equivalents) in ambient air at McMurdo, Antarctica during the 1993-1994 austral summer . 


\section{TABLES}

1. PM-10 ambient air concentration data summary for March/April 1993 and the 1993-1994

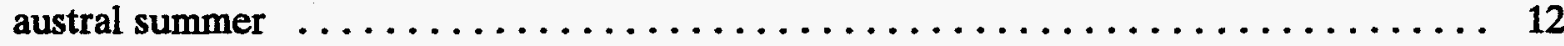

2. Summary of Gaseous air pollutant levels at central McMurdo $\ldots \ldots \ldots \ldots \ldots$

3. Summary of gaseous air pollutant levels at Hut Point $\ldots \ldots \ldots \ldots \ldots \ldots \ldots \ldots$

4. Summary of FY 1994 PCDD/PCDF ambient air sample results from McMurdo, Antarctica 23

5. Comparison of Antarctica ambient air concentration of PCDD/PCDF with those of other locations. Antarctic results are in boldface type $\ldots \ldots \ldots \ldots \ldots \ldots \ldots \ldots \ldots$ 


\section{FY 1994 Ambient Air Monitoring Report for McMurdo Station, Antarctica}

\section{INTRODUCTION}

McMurdo Station ( $77^{\circ} 51^{\prime}$ South $166^{\circ} 40^{\prime}$ East) is the largest human community in Antarctica. It is a coastal station constructed on ash and volcanic hills at the southern tip of Ross Island. McMurdo serves as the primary logistics and staging facility for airborne resupply of inland research stations and supports a wide variety of scientific research. The austral winter (March-September) population in 1993 was 264, and the austral summer (October 1993-February 1994) population was between 1,100 and 1,200 . The station consists of over 100 structures, and numerous equipment laydown and storage areas. A skiway airport located approximately $16 \mathrm{~km}$ from McMurdo and sea-ice runway approximately $5 \mathrm{~km}$ away serve fixed-wing aircraft for flights to the Antarctica mainland, as well as flights to and from New Zealand.

Emissions of atmospheric pollutants at or near McMurdo result from a variety of sources, including boilers, furnaces, space heaters, electric generators, motor vehicle engines, fugitive dust, petroleum storage tank vapors, aircraft operations, and ships. The major fixed-air emission source is the JP-8 fueled electric generation plant. Summaries of the major air emission source categories and estimated air pollutant/products of combustion emissions at McMurdo can be found in the FY 1994 Ambient Air Monitoring Plan for McMurdo Station (Lugar 1993a).

A report on the National Science Foundation (NSF) implementation of a strategy to comply with environmental law in Antarctica (NSF 1989) established the need to assess the environmental impact of air emissions at McMurdo Station and other U.S. stations. In addition, the Protocol on Environmental Protection to the Antarctic Treaty (NSF 1991) further underlined the need to implement an ambient air monitoring program. In 1992, an ambient air monitoring plan for McMurdo was prepared that established the objectives of the monitoring effort as:

(1) determine the highest concentrations of pollutants expected to occur in the area covered by the network, (2) determine representative concentrations of selected air pollutants in areas of high population density, (3) determine the impact of significant sources or source categories on ambient pollution levels, and (4) determine background levels of selected air pollutants (Lugar, 1992). This original plan was implemented during the 1992-1993 austral summer season, and the results were presented in a series of four reports (Lugar 1993b, 1993c, 1993d, 1993e). Following a review of the data from this first monitoring season, minor modifications and improvements were made to the original monitoring plan, and the FY 1994 Ambient Air Monitoring Plan was prepared to guide monitoring during the 1993-1994 austral summer season.

The objectives and performance criteria established for the monitoring network were consistent with the intent of U.S. Environmental Protection Agency State and Local Air Monitoring Stations (SLAMS) objectives and network design (40 CFR 58, Appendix D). Based on the results of the 1992-1993 austral summer monitoring, the three original sampling locations were retained for the 1993-1994 monitoring program. These locations were based on historical wind data, objectives outlined in the monitoring plan, the availability of electrical power and other operational support, and the location of major emission sources. The three monitoring sites 
utilized were: 8-Site for the predominantly upwind location, Hut Point for the predominantly downwind site, and central McMurdo, near building 155, as the "worst case urban" location (see Figure 1).

A variety of air pollutants, including many for which the EPA has established National Ambient Air Quality Standards (NAAQS), were selected for monitoring. Particulate matter with a diameter less than or equal to 10 micrometers (PM-10) was selected for monitoring particulate air pollution and the metals content of particulate matter. Gaseous air pollutants monitored continuously at Hut Point and central McMurdo included carbon monoxide (CO), sulfur dioxide $\left(\mathrm{SO}_{2}\right)$, and nitrogen oxides ( $\mathrm{NO}, \mathrm{NO}_{2}$, and $\mathrm{NO}_{x}$ ). Polychlorinated dibenzo-p-dioxins (PCDDs) and polychlorinated dibenzofurans (PCDFs) were monitored in the McMurdo area and at Black Island in order to provide a comparison with the FY 1993 results. Interim incineration of selected solid wastes was conducted during the FY 1993 season, during which time PCDDs and PCDFs were measured in the incinerator stack emission and in the ambient air at Hut Point and central McMurdo locations (Lugar 1993e). Incineration ceased on March 22, 1993; therefore, PCDD/PCDF data from FY 1994 affords the opportunity to compare ambient air quality with and without the effect of incinerator emissions.

Quality assurance and quality control requirements of the monitoring program are outlined in the FY 1994 Ambient Air Monitoring Plan for McMurdo Station, Antarctica (Lugar 1993a), and were generally consistent with EPA sampling procedures (40 CFR 50, Appendix A, C, F, and J), EPA Reference Method TO9, and the EPA Quality Assurance Handbook (EPA 1977).

The FY 1994 ambient air monitoring program was initiated in October and November 1993 by a scientist from the Idaho National Engineering Laboratory (INEL) and an environmental technician from Antarctic Support Associates (ASA). Following an initial 3-week on-the-job training period, the ASA environmental technician took over operation and maintenance of the monitoring instruments and data collection for the remainder of the austral summer season. 


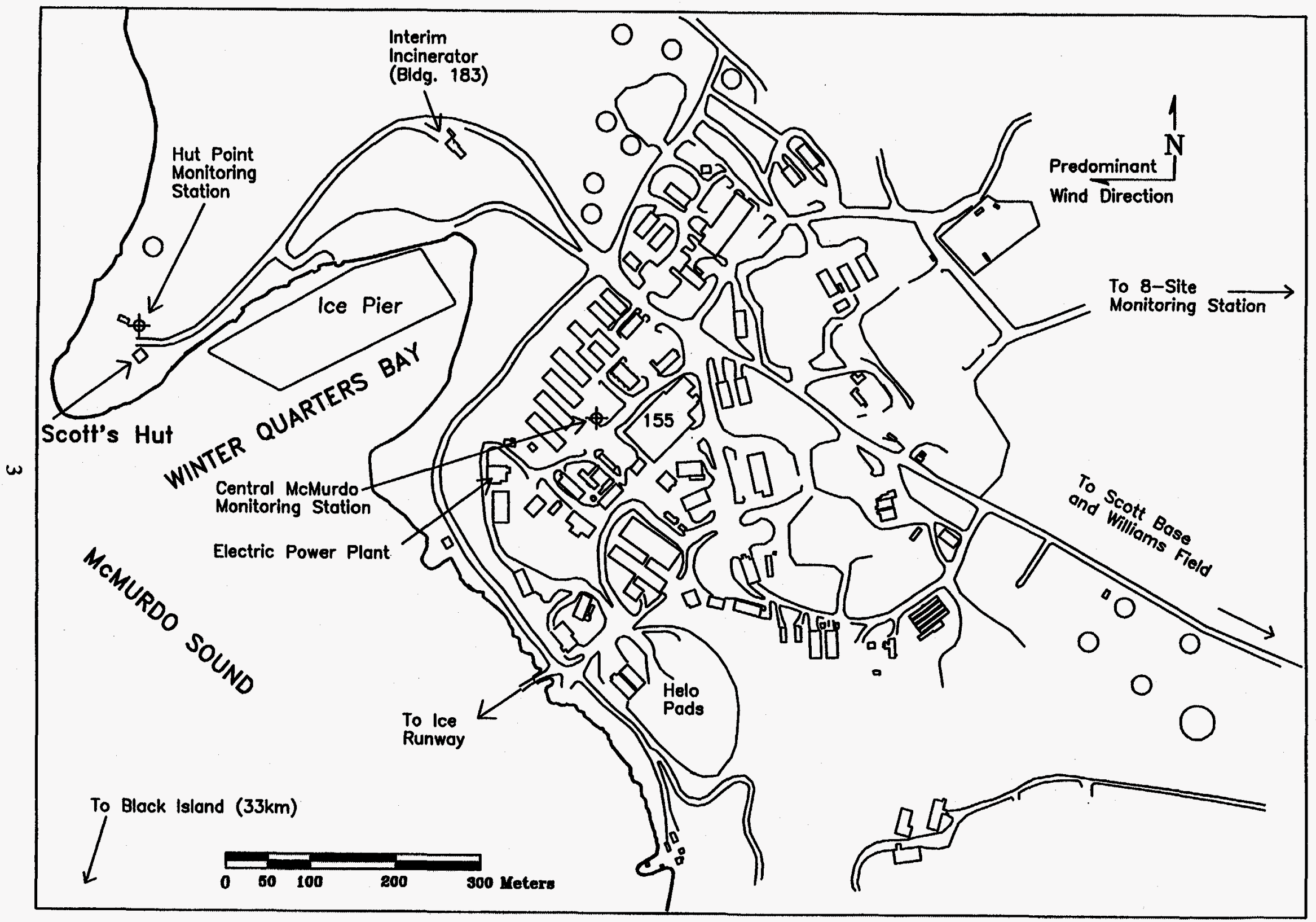

Figure 1. Map of ambient air monitoring stations at McMurdo, Antarctica. 


\section{METHODS}

PM-10: 24-hour PM-10 samples were collected concurrently at all three sites every 6 days. PM-10 samples were collected in accordance with EPA Reference Method for the Determination of Particulate Matter as PM-10 (40 CFR 50, Appendix J) using a Wedding \& Associates, Inc. PM-10 critical flow high-volume sampler (EPA Designation Number RFPS-1087-062). Particulate matter was collected on $20.3 \mathrm{~cm} \times 25.4 \mathrm{~cm}$ Whatman QM-A high-purity quartz fiber filters at a flow rate of approximately $1.13 \mathrm{~m}^{3} / \mathrm{min}$. The sample was collected over a continuous 24 -hour period from midnight to midnight (0000 to 2400). The filter was weighed (after moisture equilibration in a desiccator) before and after sampling using a Sartorius analytical balance and a special filter weighing tray. Flow calibration was performed prior to each sample collection using the manufacturer's recommended single-point flow rate audit procedure. Using this procedure in conjunction with the critical flow device, the volumetric flow rate of the system was known to within $\mathbf{0 . 7 5 \%}$. A mechanical timer and elapsed time indicator on the sampler provided a record of total elapsed sampling time.

PM-10 sampling was initiated on October 27, 1993, and continued on a 6-day frequency through February 10, 1994. A total of 55 samples were collected over this time period (approximately 18 samples per site), representing a sampling completeness of $96 \%$ (57 samples originally planned). The use of a dedicated analytical balance and filter weighing tray notably improved the precision and accuracy of the PM-10 measurements compared to the previous monitoring effort in FY 1993 (Lugar 1993b). Based on a precision assessment of the analytical balance for filter weight measurement and a typical volume of $1,800 \mathrm{~m}^{3}$ air sampled over 24 hours, the detection limit for the PM-10 measurement was approximately $0.2 \mu \mathrm{g} / \mathrm{m}^{3}$. Collocated samplers were set up for one sampling event each at Hut Point and central McMurdo locations to assess the relative sampling accuracy. The 8-Site sampler was moved to each of these locations and served as the collocated sampler for each collocated sampling event.

Field PM-10 data were recorded on field logsheets, and a computerized spreadsheet was used for subsequent calculations and data archiving.

In March and April 1993, six PM-10 measurements were successfully collected during the early austral winter. Even though these results were not reported in the FY 1993 PM-10 report (Lugar 1993b), they have been included in this report.

PM-10 Metals: One set of PM-10 samples (one sample per location) for approximately each month from October 1993 through February 1994 were designated for trace metal analysis (total of 15). In addition, two filters collected in April 1993 from Hut Point and McMurdo were submitted for trace metals analysis. Collection of these samples was intended as a followup of a similar FY 1993 effort to measure toxic metals on total suspended particulate (TSP) air samples and establish baseline information.

Following the gravimetric determination of the PM-10 concentration, each filter was placed in a glassine envelope and then placed inside a resealable plastic bag in preparation for shipment to the analytical laboratory in the United States. The samples were shipped to ASA's primary analytical contractor, G.P. Environmental Services in Gaithersburg, Maryland, then transferred to a subcontractor laboratory, Lockheed Analytical Services, in Las Vegas, Nevada for low detection 
level analysis. The samples were received at Lockheed Analytical Services on April 14, 1994, and analyzed in two analytical batches. Due to the logistical challenges of shipping samples from McMurdo to the continental U.S., it was anticipated that the EPA recommended holding time of six months for the metals of interest (except mercury at twenty-eight days) may be exceeded. It was known that the 28 day holding time for samples undergoing mercury analysis would be exceeded.

The filter samples were prepared for analysis by digesting the whole filter in $200 \mathrm{~mL}$ of $10 \%$ nitric acid (trace metal grade) in a $250 \mathrm{~mL}$ beaker for 2 hours at $95^{\circ} \mathrm{C}$. After digestion, the samples were cooled and filtered through Whatman \#1 filters into 200 -mL class A volumetric flasks and then diluted to volume. The samples were then split into two 100-mL aliquots: one aliquot for direct analysis by inductively coupled plasma/mass spectrometry (ICPMS), and the other aliquot to be digested further for subsequent mercury analysis via EPA Method SW-846 7050, and analyzed for mercury using cold vapor atomic adsorption spectroscopy via EPA Method 7470. The other aliquot of leachate was analyzed directly by inductively coupled plasma/mass spectrometry (ICPMS) for arsenic, beryllium, cadmium, chromium, lead, and nickel in accordance with EPA SW-846 Method 6020 (EPA 1986). The concentrations reported by the analytical laboratory ( $\mu \mathrm{g}$ of metal per total filter) were then divided by the total air volume sampled to obtain air concentration units $\left(\mathrm{ng} / \mathrm{m}^{3}\right)$. Quality assurance and data reporting requirements of the EPA Contract Laboratory Program (CLP) were used, and an unused filter (blank) was analyzed to assess trace metal contaminants associated with the filter. Data validation consisted of a review of the CLP metals data package received from the analytical laboratory for completeness, and quality control compliance.

$\mathrm{CO}, \mathrm{SO}_{2}$, and $\mathrm{NO} / \mathrm{NO}_{2}, \mathrm{NO}_{x}:$ Each set of gas analyzers was housed in an insulated, temperature-controlled weather shelter. The weather shelters provided the necessary room-temperature operating environment for the analyzers, and were designed to keep the internal shelter temperature as stable as possible, thereby optimizing the analyzer measurement stability. Each shelter also contained a zero air supply, gas calibration system, data logger, calibration gas cylinders, electrical outlets, and internal lighting. Electricity (110 Vac) was provided to each shelter from nearby power lines. Due to the potential for unstable line power and occasional outages, each shelter also included a power sifter, two uninterrupted power supplies (UPSs), and two surge protectors to minimize data loss and protect the monitoring system from damage. Each analyzer utilized a nominal $6.4-\mathrm{mm}$ ID Teflon ${ }^{\mathrm{TM}}$ inlet particulate filter. Each shelter had a single roof penetration for an inverted U-shaped PVC pipe assembly that housed a bundle of three inlet lines and provided protection of the inlet tube openings from blowing snow and dust.

The gas analyzers, gas calibration systems, and zero air supplies were manufactured by Thermo Environmental Inc. All analyzers were calibrated using a Matheson National Institute of Standards and Technology (NIST) traceable certified gas standard, a Model 111 Zero Air Supply, and a Model 146 Gas Calibration System. Multipoint calibration curves were prepared for all instruments during start up of the monitoring program, and on a monthly basis thereafter. Zero and span checks were performed at least bi-weekly.

CO was measured continuously using a Model 48 Gas Filter Correlation (GFC) Ambient CO Analyzer. This instrument is designated by the EPA as a Reference Method (40 CFR 50 
Appendix C), and holds designation reference method number RFCA-0981-054. It is not available in a more sensitive model as are the $\mathrm{SO}_{2}$ and $\mathrm{NO}_{x}$ analyzers, and has a minimum detectable limit of 0.1 parts per million ( $\mathrm{ppm}$ ).

$\mathrm{SO}_{2}$ was continuously monitored using a Model 43S High Sensitivity Pulsed Fluorescence $\mathrm{SO}_{2}$ Analyzer. Although this instrument does not have an EPA designation as a compliance monitor, it is identical to the EPA designated Model 43A in most respects (EPA Equivalent Method to 40 CFR 50 Appendix A). The principal difference in the Model $43 \mathrm{~S}$ is improved sensitivity (lower detectable limit of $0.1 \mathrm{ppb} \mathrm{SO}_{2}$ ), and associated lower operating ranges (minimum range of $10 \mathrm{ppb}$, maximum range or $200 \mathrm{ppb}$ ). The Model $43 \mathrm{~S}$ was selected because the ambient $\mathrm{SO}_{2}$ levels at $\mathrm{McMurdo}$ were suspected to be in the $\mathrm{ppb}$ range or lower.

$\mathrm{NO} / \mathrm{NO}_{2} / \mathrm{NO}_{\mathrm{x}}$ was continuously measured using a Model $43 \mathrm{~S}$ Chemiluminescence Low Level NO-NO $-\mathrm{NO}_{\mathrm{x}}$ Analyzer. This instrument does not have an EPA designation as a reference method monitor; however, it is very similar to the EPA designated Model 42; the main difference being the improved sensitivity of the Model $42 \mathrm{~S}$ (minimum detectable limit of 50 parts per trillion). Data were collected in accordance with the EPA Reference Method described in 40 CFR 50 Appendix F.

The data logger used in each shelter was an Environmental System Corporation (ESC) Model 8800, programmed to perform hourly averaging and storage of the analyzer outputs. In addition, a multichannel chart recorder was used in each shelter to provide additional real-time record of the analyzer output during calibration, span and zero checks, and initial operation. Field logsheets were used to record calibration, zero/span checks, and maintenance information. A computerized spreadsheet was used to perform regression analysis of the calibration data and correct the gas concentration data sets. Gas concentration data were routinely downloaded from the data logger to a floppy diskette, and subsequently transferred and parsed in a computerized spreadsheet.

The FY 1994 Ambient Air Monitoring Plan intended that one set of analyzers be fixed at the downwind Hut Point location, and the other set of analyzers rotated between the central McMurdo and 8-Site locations to permit collection of baseline data for these locations. Due to a malfunction of the $\mathrm{NO} / \mathrm{NO}_{2} / \mathrm{NO}_{x}$ analyzer at the central McMurdo location, this set of analyzers was not moved to the 8-Site, and the gas data for FY 1994 include concentrations of $\mathrm{CO}, \mathrm{SO}_{2}$, and $\mathrm{NO} / \mathrm{NO}_{2} / \mathrm{NO}_{x}$ at Hut Point and only $\mathrm{CO}$ and $\mathrm{SO}_{2}$ at central McMurdo. Continuous operation of the gas analyzers was initiated on November 2, 1993, at Hut Point, and November 4, 1993, at central McMurdo. Both sets of analyzers were shut down for the winter on February 13, 1994.

PCDDs/PCDFs: Polychlorinated dibenzo-p-dioxins (PCDDs) and polychlorinated dibenzofurans (PCDFs), collectively designated as dioxin/furans, were monitored in ambient air at the three McMurdo air monitoring locations and at Black Island. The cessation of incineration at McMurdo for the 1993-1994 summer season provided an opportunity for comparison of ambient air dioxin/furan results to the 1992-1993 data when incineration was in effect. Samples were collected in accordance with EPA Reference Method T09, Method for the Determination of Polychlorinated Dibenzo-p-Dioxins (PCDDs) in Ambient Air Using High-Resolution Gas Chromatography/High-Resolution Mass Spectrometry (HRGC/HRMS). Samples were collected 
using a General Metal Works Model PS-1 PUF Sampler with a flow rate of approximately $0.27 \mathrm{~m}^{3} / \mathrm{min}$. The method consists of sampling ambient air via an inlet glass fiber filter followed by a glass cartridge filled with a polyurethane foam (PUF) plug.

Flow calibration curves were prepared for each sampler prior to the collection of the first sample. An elapsed time indicator on the sampler provided a record of sampling time. The PUF plugs were cleaned and then spiked with 800 picograms each of ${ }^{13} \mathrm{C}_{12}-1,2,3,4-\mathrm{TCDD}$ by the EPA Environmental Chemistry Laboratory (ECL) at Stennis Space Center, Mississippi. Following sample collection, the filters and PUF plugs were extracted by the same laboratory, and the extracts then analyzed by the EPA Atmospheric Research and Exposure Assessment Laboratory (AREAL) in Research Triangle Park, North Carolina. Field blanks, laboratory method blanks, and fortified laboratory method blanks (laboratory spikes) were utilized for quality assurance purposes.

Beginning on November 23, 1993, one set of air samples from each of the three McMurdo area locations were collected over a 48-hour period on a monthly basis through February 3, 1994, for dioxin/furan analysis (total of 12 samples). From November 30, 1993, through December 5, 1994, a dc-powered PUF sampler was deployed at Black Island, and a single 121-hour sample was collected. Two field blanks were included with the regular samples for quality assurance purposes. The glass fiber filters and associated PUF plugs were retrieved as soon as possible after the conclusion of the sampling, wrapped in aluminum foil and placed in a resealable plastic bag to minimize exposure to the ambient air and light. The samples were stored at room temperature at McMurdo until the end of the summer season, at which time they were shipped to the continental U.S. for analysis. Field logsheets were used to record PUF sampling information, and a computerized spreadsheet used for calculations and data archiving.

The analytical procedures used (Harless 1992; revised EPA Reference Method T09) are similar to those in EPA Method 8290 and EPA Method 1613. Sample preparations were performed on a set of 16 samples, which consisted of 12 test samples, field blanks, method blank, and a fortified method blank. Each respective glass fiber filter and PUF were combined, spiked with nine ${ }^{13} \mathrm{C}_{12}$ - labeled PCDD/PCDF internal standards, and then Soxhlet extracted with benzene for 16 hours. Each extract was then subjected to an acid base clean up procedure followed by clean up on micro columns of silica gel, alumina, and carbon. Each extract was concentrated to $0.5 \mathrm{~mL}$. An aliquot of the recovery standard containing $0.5 \mathrm{ng}{ }^{37} \mathrm{Cl}_{4}-2,3,7,8-$ TCDD was then spiked to each extract. The extracts were concentrated to $30 \mu \mathrm{L}$, quantitatively transferred to respective $2 \mathrm{~mm}$ i.d. X $75 \mathrm{~mm}$ glass tubes, and fire-sealed for shipment to EPA AREAL at Research Triangle Park, North Carolina for analysis.

A Finnigan MAT 90 HRGC-HRMS system operating in the electron impact ionization and multiple ion detection mode at 7,000 to 10,000 mass resolution was used for the analysis of samples. Chromatographic resolution of components was accomplished using a $30 \mathrm{~m}$ DB-5 fused silica capillary column and/or a $60 \mathrm{~m}$ SP-2331 fused silica capillary column for resolution of 2,3,7,8-substituted congeners, isomer specific analysis. The peak areas of the exact masses of the molecular ion clusters of the labeled and unlabeled PCDDs and PCDFs and respective response factors were used for quantification purposes. The ${ }^{37} \mathrm{Cl}_{4}-2,3,7,8-\mathrm{TCDD}$, spiked to the sample extract prior to final concentration, was used to determine the method efficiency, recovery of the nine ${ }^{3} \mathrm{C}_{12}$-labeled internal standards. The recovery of the ${ }^{13} \mathrm{C}_{12}-1,2,3,4-\mathrm{TCDD}$ that was spiked to 
the PS-1 filter prior to ambient air sampling was used to determine the PS-1 air sampler collection and retention efficiency for the sampling period. The nine labeled PCDD and PCDF internal standards and respective response factors were used for quantification of unlabeled PCDDs and PCDFs and for determination of method detection limits (MDLS). For example, the ${ }^{13} \mathrm{C}_{12}$ 2,3,7,8-TCDD was used to quantify the 2,3,7,8-TCDD isomer and all other TCDD isomers present or to determine the MDLs. The ${ }^{13} \mathrm{C}_{12}-\mathrm{OCDD}$ was used in a similar manner for OCDD and $O C D F$.

The data achieved for a set of samples was evaluated using defined analytical criteria and QAVQC criteria and requirements. The acceptance criteria for data include: acceptable chlorine isotope ratios, retention time, signal-to-noise ratio, PS-1 collection and retention efficiency, method efficiency, accuracy and precision achieved for laboratory method spike or control sample, method blank free of significant PCDD and PCDF contamination, and analysis that confirmed the absence of chlorinated diphenylethers. 


\section{RESULTS}

PM-10: PM-10 levels at McMurdo during the 1993-1994 austral summer were well below the U.S. National Ambient Air Quality Standard of $50 \mu \mathrm{g} / \mathrm{m}^{3}$ (annual arithmetic mean) and $150 \mu \mathrm{g} / \mathrm{m}^{3}$ (24 hour maximum), with the central McMurdo location exhibiting a summer seasonal PM-10 average of $9.8 \mu \mathrm{g} / \mathrm{m}^{3}$. Generally, PM-10 levels at all sampling locations were lower during the 1993-1994 austral summer compared to the 1992-1993 season. A graphical summary of the data collected during the 1992-1993 and 1993-1994 austral summer seasons is provided on Figures 2 and 3, respectively. Also included on Figure 2 are data from March and April 1993 (winter), the only PM-10 data collected at McMurdo during the winter. Table 1 contains the March/April 1993 and the 1993-1994 austral summer PM-10 results in tabular form for future reference.

During the 1993-94 summer sampling, PM-10 concentrations ranged from 0.6 to $3.2 \mu \mathrm{g} / \mathrm{m}^{3}$ measured at 8-Site, to a maximum concentration of $16.4 \mu \mathrm{g} / \mathrm{m}^{3}$ measured at the central McMurdo site. The correlation between PM-10 concentration and location was again observed, with the central McMurdo location exhibiting the highest PM-10 levels (seasonal arithmetic mean of $9.8 \mu \mathrm{g} /$ ), followed by lower concentrations at Hut Point (seasonal arithmetic mean of $3.7 \mu \mathrm{g} / \mathrm{m}^{3}$ ), and the lowest PM-10 levels observed at 8-Site (seasonal arithmetic mean of $1.6 \mu \mathrm{g} / \mathrm{m}^{3}$ ). The higher PM-10 concentrations observed at central McMurdo are most likely attributed to both combustion-sourced particulate emissions and resuspended road dust from local vehicular traffic.

The collocated PM-10 sampling event at central McMurdo on December 27, 1993, and Hut Point on January 1, 1994, demonstrated results with a relative percent difference of $9.5 \%$ and $0 \%$, respectively. These values indicate satisfactory sampling procedures and sampler performance, and acceptable relative sampling accuracy. Only one sample from 8-Site (October 27, 1993) was rejected due to the presence of grit particles and brush bristles on the filter. This extraneous matter, which is believed to have been dislodged after the recommended annual cleaning of the inlet, probably contributed significantly to the final weight of the filter paper; for this reason, the resulting value was rejected. One other sample planned for December 21, 1993 at 8-Site was not collected due to motor brush replacement and preparation of the sampler at this location for future collocation at central McMurdo. All the PM-10 air samplers required replacement of the motor brushes during the FY 1994 monitoring season. This was expected based on the manufacturer's specifications that recommend replacement of the brushes after 200 hours of operation. Brushless motors with an estimated 20,000-hour maintenance-free life have recently been developed for high-volume PM-10 air samplers, and these should be considered for replacing the existing brush-type motors.

PM-10 Metals: The number of toxic metal species detected and their concentrations were correlated to sampling location. The predominantly upwind 8-Site generally exhibited the lowest number of metal species detected and the lowest concentrations, while the central McMurdo samples exhibited the highest number of metal species detected and the highest concentrations. The reported concentration of all seven toxic metals of interest at all three locations are well below the U.S. National Ambient Air Quality Standards and American Conference of Governmental Industrial Hygienists Threshold Limit Values (TLVs) for chemical substances. Figures 4 through 6 provide graphical metal concentration profiles for the seven toxic metals of interest at all three sampling locations. The results of the analysis of PM-10 filters collected in 


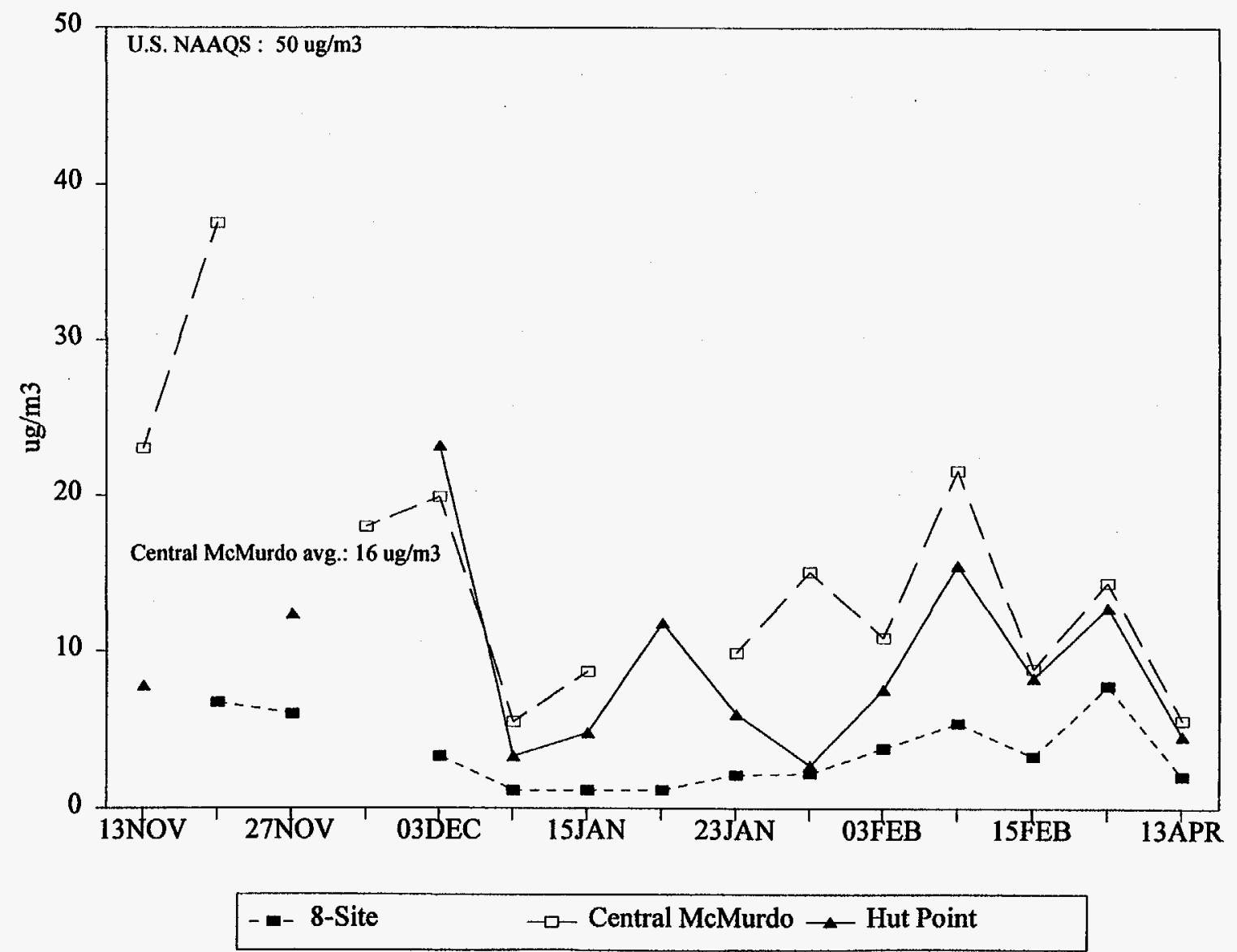

Figure 2. PM-10 levels at three sites near McMurdo, Antarctica during the 1992-1993 austral summer and March/April 1993. 


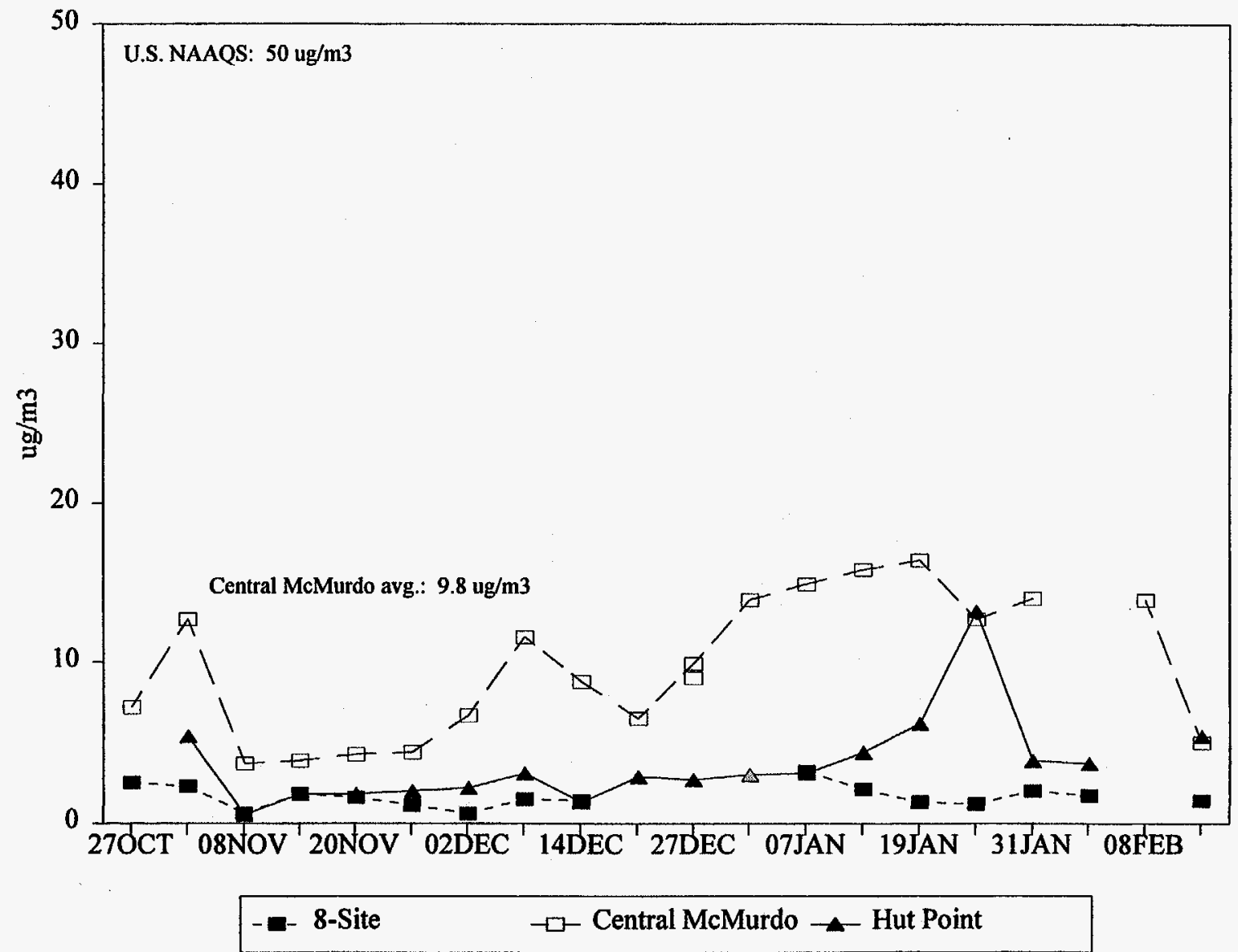

Figure 2. PM-10 levels at three sites near McMurdo, Antarctica during the 1993-1994 austral summer. 
Table 1. PM-10 ambient air concentration data summary for March/April 1993 and the 1993-1994 austral summer.

\begin{tabular}{|c|c|c|c|c|}
\hline Date & $\begin{array}{c}\text { Filter series } \\
\text { or } \#\end{array}$ & $\begin{array}{c}\text { 8-site } \\
\text { (Sampler \#519) } \\
\mu \mathrm{g} / \mathrm{m}^{3}\end{array}$ & $\begin{array}{c}\text { Central McMurdo } \\
\text { (Sampler \#518) } \\
\mu \mathrm{g} / \mathrm{m}^{3}\end{array}$ & $\begin{array}{c}\text { Hut point } \\
\text { (Sampler \#520) } \\
\mu \mathrm{g} / \mathrm{m}^{3}\end{array}$ \\
\hline 07MAR93 & MCO2R, HP02R & - & 14.4 & 12.8 \\
\hline 08MAR93 & TSO2R & 7.8 & - & - \\
\hline 12APR93 & TS03R, MC03R, HP03R & 2.9 & 5.6 & 4.6 \\
\hline $270 C T 93$ & 09 & 2.5 & 7.2 & 11.6 (a) \\
\hline 02NOV93 & 08 & 2.3 & 12.7 & 5.4 \\
\hline 08NOV93 & 10 & 0.6 & 3.7 & 0.5 \\
\hline 14NOV93 & 11 & 1.8 & 3.9 (b) & 1.8 \\
\hline 20NOV93 & 12 & 1.6 & 4.3 & 1.8 \\
\hline 26NOV93 & 13 & 1.1 & 4.4 & $2.0(c)$ \\
\hline $02 \mathrm{DEC} 93$ & 14 & 0.6 & 6.7 & 2.2 \\
\hline 08DEC93 & 15 & 1.5 & 11.6 & 3.1 \\
\hline 14DEC93 & 16 & $1.4(b)$ & 8.8 & 1.3 \\
\hline 21DEC93 & 17 & not collected & 6.5 & 2.9 (b) \\
\hline $27 \mathrm{DEC} 93$ & 18 & $\begin{array}{l}\text { collocated at } \\
\text { central McMurdo }\end{array}$ & $\begin{array}{l}9.9(\# 518) \\
9.0(\# 519)\end{array}$ & 2.7 \\
\hline 01JAN94 & 19 & $\begin{array}{l}\text { collocated at Hut } \\
\text { Point }\end{array}$ & 13.9 & $\begin{array}{l}3.0(\# 520) \\
3.0(\# 519)\end{array}$ \\
\hline 07JAN94 & 20 & 3.2 & 14.9 & 3.1 \\
\hline 13JAN94 & 21 & 2.1 & 15.8 & 4.4 \\
\hline 19JAN94 & 22 & 1.3 (d) & 16.4 (d) & $6.2(d)$ \\
\hline 25JAN94 & 23 & 1.2 & 12.7 (b) & 13.2 \\
\hline 31JAN94 & 24 & 2.0 & 14.0 & 3.9 \\
\hline 06FEB94 & 25 & 1.7 & $13.9(\mathrm{e})$ & 3.7 \\
\hline 10FEB94 & 26 & 1.4 & 5.0 & 5.4 \\
\hline \multicolumn{5}{|c|}{ a. Small stones and cleaning brush bristles found on filter after sampling, sample deemed invalid. } \\
\hline \multicolumn{5}{|c|}{ b. Sampler may have stopped during 24 hour sampling period. } \\
\hline \multicolumn{5}{|c|}{ c. Bulldozers working on ice pier. } \\
\hline \multicolumn{5}{|c|}{ d. No information on wind direction and speed available. } \\
\hline e. Sampl & February 8, 1994. & & & \\
\hline
\end{tabular}



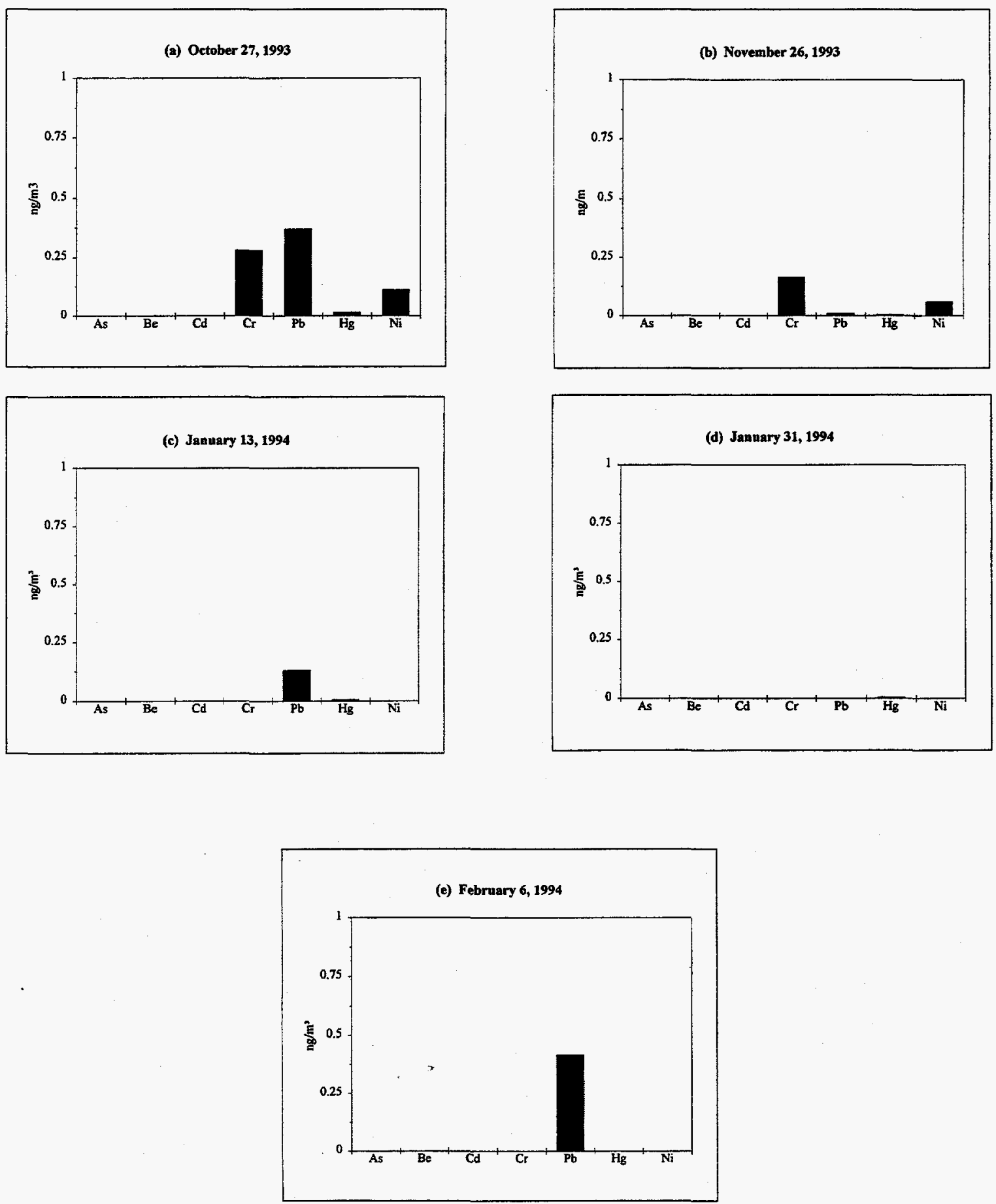

Figure 4. PM-10 metals concentrations at 8-Site. 

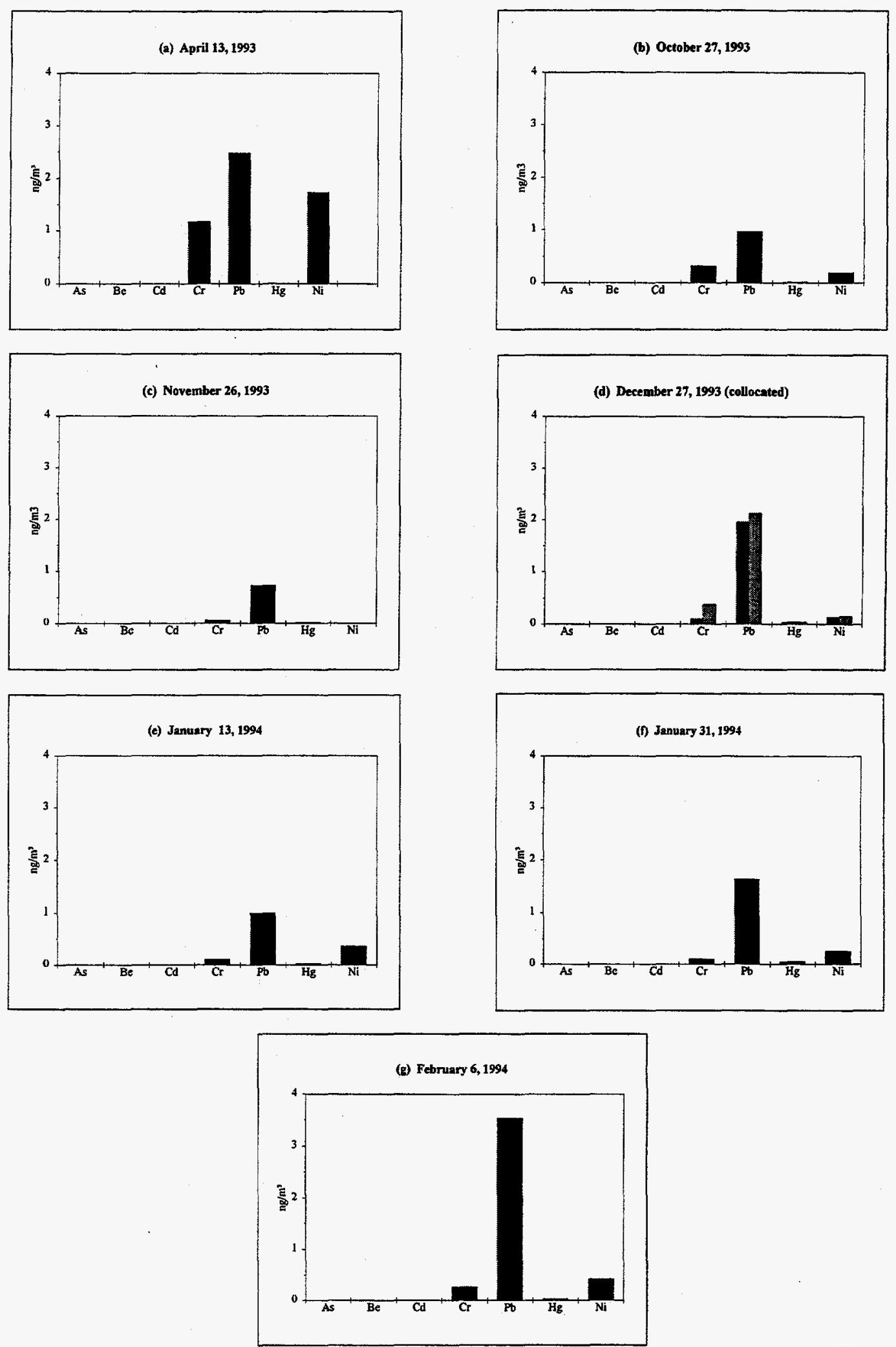

Figure 5. PM-10 metals concentrations at Central McMurdo. 

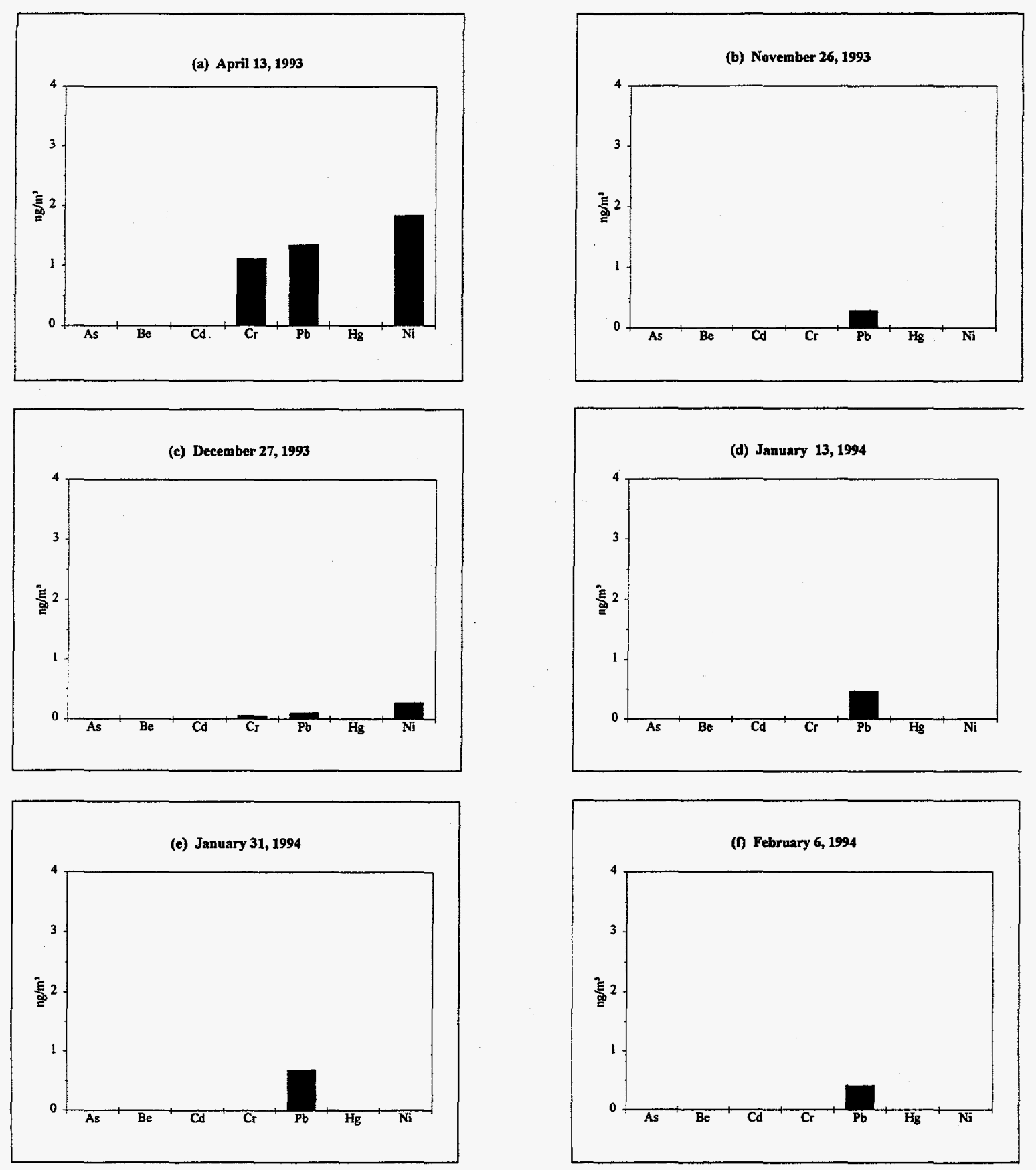

Figure 6. PM-10 metals concentrations at Hut Point. 
the early winter (April 13) of 1993 from Hut Point and central McMurdo are also presented on Figures 5 and 6.

Arsenic, beryllium, and cadmium were not detected on any samples (detection limit approximately $0.1 \mathrm{ng} / \mathrm{m}^{3}$, based on $1,800-\mathrm{m}^{3}$ air sample volume). Lead was the predominant metal of the seven toxic metals of interest found on the air filters, and was detected on all samples analyzed from central McMurdo and Hut Point, ranging in concentration from 0.11 to $3.5 \mathrm{ng} / \mathrm{m}^{3}$. Lead was detected in four of the five samples collected at 8-Site at levels ranging from 0.01 to $0.42 \mathrm{ng} / \mathrm{m}^{3}$. These lead concentrations are well below the U.S. NAAQS of $1,500 \mathrm{ng} / \mathrm{m}^{3}$ (maximum arithmetic mean averaged over a calendar quarter).

Chromium and nickel were the next most prevalent toxic metals detected, and were found primarily on samples from central McMurdo and one sample from Hut Point at concentrations ranging from below the detection limit $\left(<0.1 \mathrm{ng} / \mathrm{m}^{3}\right)$ to $1.17 \mathrm{ng} / \mathrm{m}^{3}$ for chromium and from below the detection limit $\left(<0.1 \mathrm{ng} / \mathrm{m}^{3}\right)$ to $1.84 \mathrm{ng} / \mathrm{m}^{3}$ for nickel. Trace levels $\left(0.01\right.$ to $\left.0.05 \mathrm{ng} / \mathrm{m}^{3}\right)$ of mercury were reported on all six central McMurdo samples. In addition to lead detected in most 8-Site samples, two 8-Site samples exhibited chromium at 0.28 and $0.17 \mathrm{ng} / \mathrm{m}^{3}$, and nickel at 0.11 and $0.06 \mathrm{ng} / \mathrm{m}^{3}$.

Results of the analysis of an unused filter (field blank) indicated detectable levels of chromium, lead, and nickel at $1.6 \mu \mathrm{g} /$ filter, $0.74 \mu \mathrm{g} /$ filter, and $0.61 \mu \mathrm{g} /$ filter, respectively. These blank values were used to correct the entire PM-10 metals data set, and all metal concentrations reported herein are corrected values. Reported chromium, lead, and nickel concentrations at or below the detection limit of $0.1 \mathrm{ng} / \mathrm{m}^{3}$ may be due to the presence of these metals as contaminants of the filters and/or the actual presence of these metal species as particulate matter collected on the filter.

Evaluation of the mass-of-metal to mass-of-particulate ratio of these samples is useful to assess whether the source(s) contributing to an increase in airborne metal concentration is due to combustion emissions or increased loading of crustal-derived dust. Figure 7 provides a graphical comparison of these metal to particulate ratios for each month at the three sampling locations.

The April 12, 1993 (winter) sample data only included metal results for the central McMurdo and Hut Point locations; however, the metal-to-particulate ratio values were notably higher in these samples than any samples collected during the summer. The October 27, 1993 samples for 8-Site and central McMurdo exhibited relatively similar metal-to-particulate ratios. An explanation of the cause of these elevated levels and ratios for the winter sample is hampered since only two samples from the winter were analyzed for metals.

On November 26, 1993, the ratio of lead to PM-10 concentration was notably higher at Hut Point and central McMurdo than at 8-Site; however, the 8-Site exhibited unusually elevated chromium and nickel levels. On December 2, 1993, there was no sample collected at 8-Site; the Hut Point sample exhibited notably lower lead-to-PM-10 ratio as compared to the two collocated central McMurdo samples; however, the Hut Point sample also exhibited a notably higher nickelto-PM-10 ratio as compared to central McMurdo. The lead-to-PM-10 ratios were similar at all three locations for the January 13, 1994 and February 6, 1994 samples. These data indicate that there was no consistent measurable evidence of toxic metals "enrichment" of the airborne PM-10 

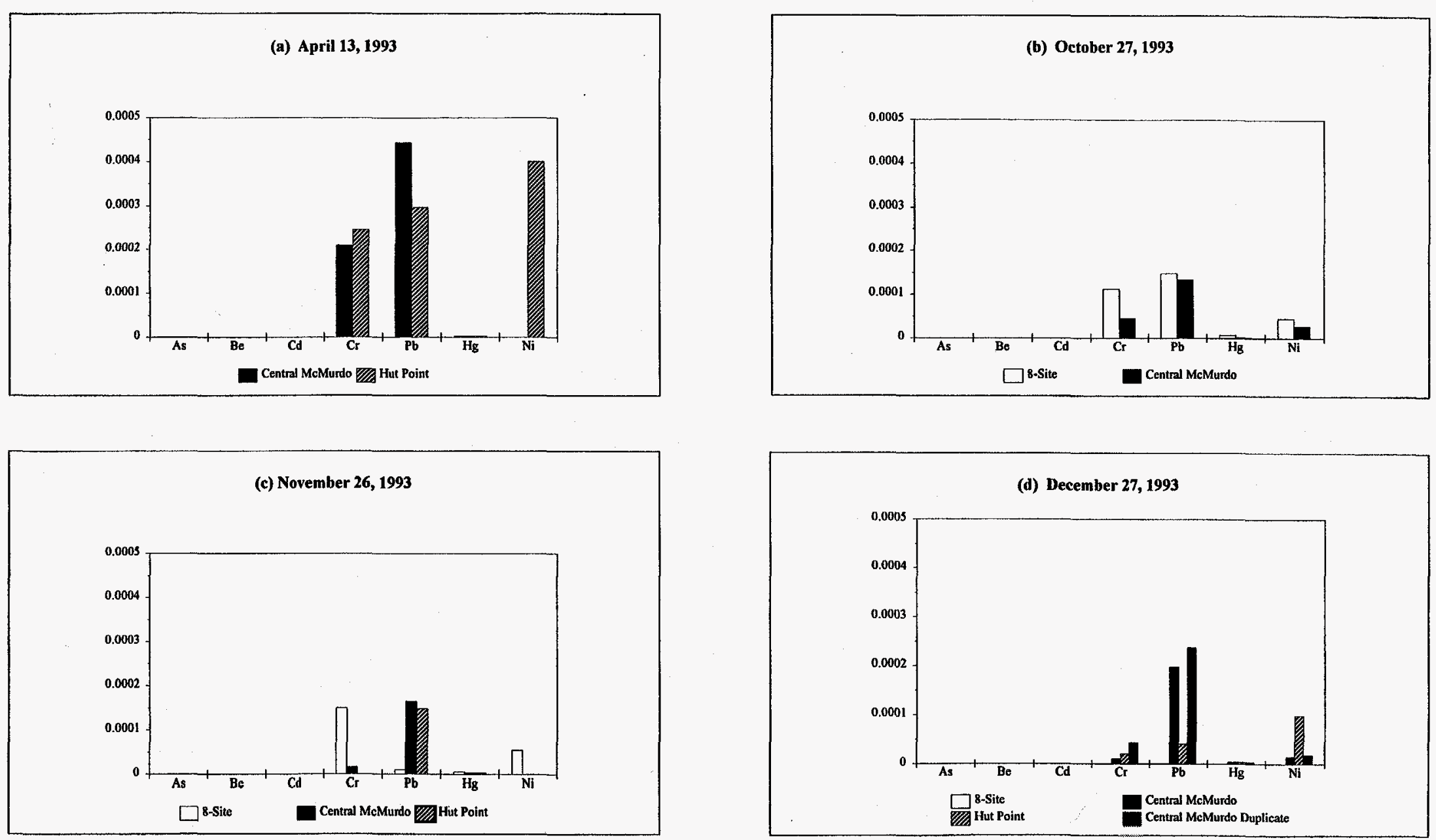

Figure 7. Metals to PM-10 ratios. 

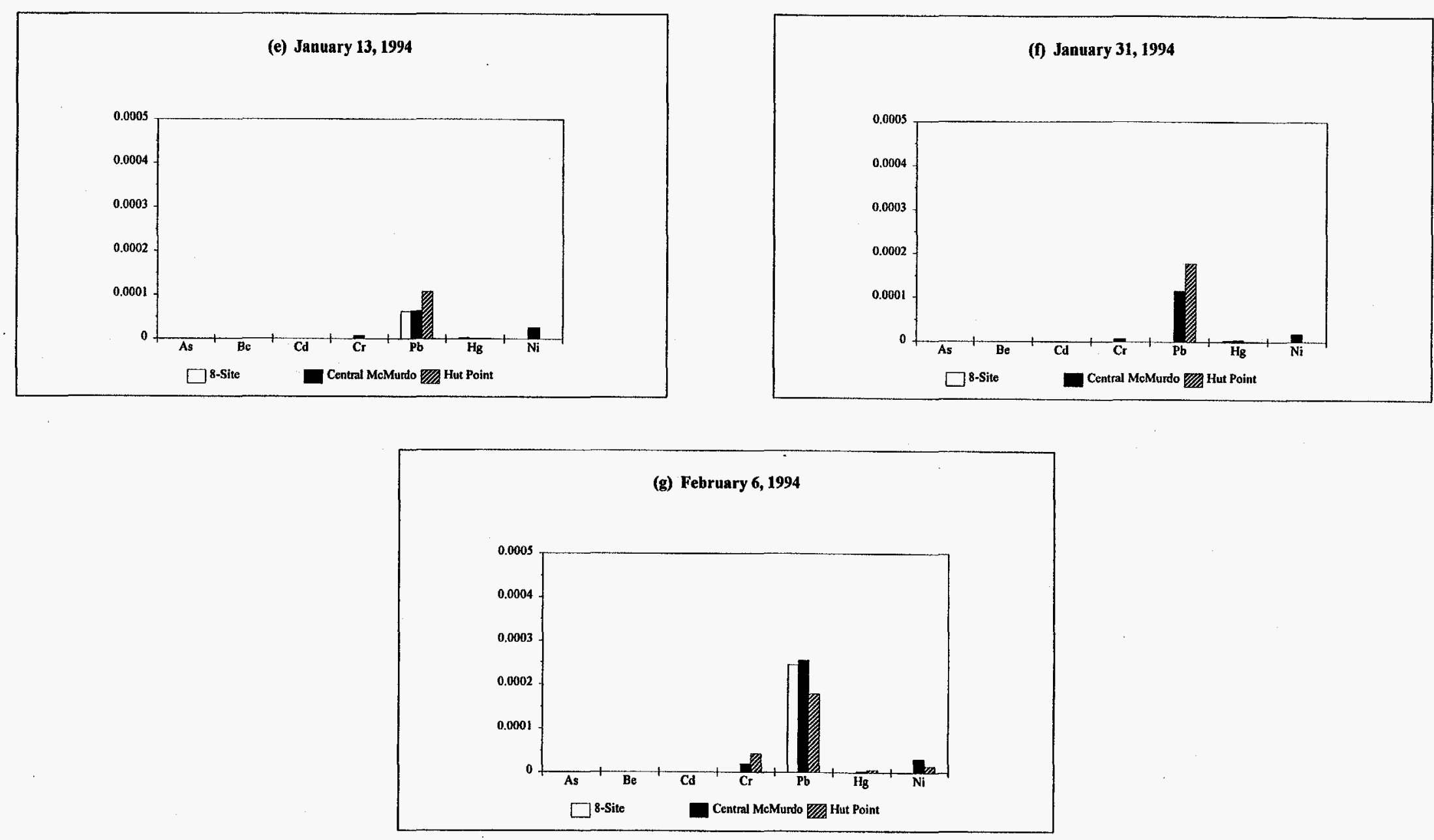

Figure 7. (continued). 
particulate matter by operations at McMurdo; however, the very low metal concentrations present and the low mass loading of particulate matter on a 24-hour sample make an accurate determination difficult.

The data and conclusions derived from these samples are generally consistent with the FY 1993 metals analysis of a limited number (7) of total suspended particulate (TSP) air filter samples from McMurdo (Lugar 1994); however, the absolute air concentrations of the detected metals are lower for the FY 1994 PM-10 samples. These lower metal concentrations may be attributed to both a lower mass loading on the filters for PM-10 as compared to TSP, and the overall lower levels of airborne particulate matter observed during the FY 1994 season. Additionally, the type and relative amounts of the metals detected for a given sampling location were generally similar for the FY 1994 and FY 1993 data sets.

$\mathrm{CO}, \mathrm{SO}_{2}$, and $\mathrm{NO} / \mathrm{NO}_{2} / \mathrm{NO}_{x}:$ Ambient levels of these gaseous air pollutants in the McMurdo locale were well below the EPA National Ambient Air Quality Standards during the monitoring period (November 2, 1993 through February 13, 1994). Summaries of gaseous air pollutant levels at Hut Point and central McMurdo are presented in Tables 2 and 3. Plots of hourly average gas concentrations during November, December, January, and February at the central McMurdo and Hut Point locations are provided in Appendix A. Seasonal average CO levels were near the analyzer detection limit at both monitoring locations: $0.37 \mathrm{ppm}$ at central $\mathrm{McMurdo}$ and $0.15 \mathrm{ppm}$ at Hut Point. Seasonal average $\mathrm{SO}_{2}$ levels at both locations were less than the 0.1-ppb analyzer detection limit. Nitrogen oxide levels at central McMurdo were planned for measurement; however, a defective analyzer prevented collection of these data at this location. Nitrogen oxide levels were successfully measured at Hut Point, with seasonal averages of $\mathrm{NO}$ at $3.5 \mathrm{ppb}, \mathrm{NO}_{2}$ at $2.0 \mathrm{ppb}$, and $\mathrm{NO}_{\mathrm{x}}$ at $5.5 \mathrm{ppb}$.

The highest hourly average and maximum hourly average values for all measured gaseous air pollutants were recorded during January 1994 at Hut Point. The increased concentrations at Hut Point during January are most likely due to increased vehicular activity and ship emissions at the nearby ice pier during ship off-load/loading operations. Hourly average $\mathrm{CO}$ concentrations at Hut Point typically ranged from the instrument detection limit of 0.1 to $0.2 \mathrm{ppm}$, with the seasonal maximum hourly average concentration of $0.5 \mathrm{ppm}$ measured in January. The Hut Point CO analyzer experienced a malfunction between November 30, 1993 and December 8, 1993 due to unknown causes, resulting in lost data during that time period. Average monthly $\mathrm{SO}_{2}$ concentrations at Hut Point (based on hourly average data) ranged from below the detection limit of $0.1 \mathrm{ppb}$ for November and December, and $0.1 \mathrm{ppb}$ for January and February. The single maximum hourly average $\mathrm{SO}_{2}$ concentration for the season was $5.6 \mathrm{ppb}$ recorded in January. Average monthly NO levels at Hut Point ranged from $0.7 \mathrm{ppb}$ to $10.4 \mathrm{ppb}$, with a maximum hourly average of $180.5 \mathrm{ppb}$ occurring in January. $\mathrm{NO}_{2}$ monthly averages ranged from below the detection limit of $0.03 \mathrm{ppb}$ to $6.7 \mathrm{ppb}$, with the maximum hourly average concentration of $24.9 \mathrm{ppb}$ recorded in December. $\mathrm{NO}_{\mathrm{x}}$ monthly averages ranged from $0.2 \mathrm{ppb}$ to $12.6 \mathrm{ppb}$, with the maximum hourly average concentration of $186.4 \mathrm{ppb}$ measured in January.

$\mathrm{CO}$ levels (monthly average) at the central McMurdo location were slightly higher than Hut Point, ranging from 0.3 to $0.5 \mathrm{ppm}$, with a maximum hourly average value of $1.0 \mathrm{ppm}$ observed in November and December. Instrument drift of 0.1 to $0.3 \mathrm{ppm}$ was observed between the monthly calibrations. Monthly average $\mathrm{SO}_{2}$ concentrations at central McMurdo were below detection 
Table 2. Summary of gaseous air pollutant levels at central McMurdo.

\begin{tabular}{|c|c|c|c|c|c|c|c|c|c|c|c|}
\hline \multirow[b]{2}{*}{ Gas type } & \multicolumn{2}{|c|}{ November } & \multicolumn{2}{|c|}{ December } & \multicolumn{2}{|c|}{ January } & \multicolumn{2}{|c|}{ February } & \multirow[b]{2}{*}{ U.S. NAAQS } & \multirow[b]{2}{*}{ Background } & \multirow[b]{2}{*}{ Urban } \\
\hline & Avg. & $\begin{array}{l}\text { Max } \\
\text { hourly } \\
\text { avg. }\end{array}$ & Avg. & $\begin{array}{c}\text { Max } \\
\text { hourly } \\
\text { avg. }\end{array}$ & Avg. & $\begin{array}{l}\text { Max } \\
\text { hourly } \\
\text { avg. }\end{array}$ & Avg. & $\begin{array}{l}\text { Max } \\
\text { hourly } \\
\text { avg. }\end{array}$ & & & \\
\hline $\begin{array}{c}C O \\
(p p m)\end{array}$ & 0.5 & 1.0 & 0.3 & 1.0 & 0.4 & 0.9 & 0.3 & 0.9 & $\begin{array}{l}\text { 8-hour avg.: } 10 \mathrm{mg} / \mathrm{m}^{3} \\
(8.6 \mathrm{ppm}) \\
\text { 1-hour max.: } 40 \mathrm{mg} / \mathrm{m}^{3} \\
(34.9 \mathrm{ppm})\end{array}$ & $\begin{array}{l}100 \mathrm{ppb}^{\mathrm{a}}(0.1 \mathrm{ppm}) \\
40-70 \mathrm{ppb} @ \text { South Pole }\end{array}$ & $\begin{array}{l}1.1-1.6 \mathrm{ppm}^{\mathrm{f}} \\
\text { (U.S.) }\end{array}$ \\
\hline $\begin{array}{l}\mathrm{SO}_{2} \\
(p p b)\end{array}$ & $\begin{array}{l}\text { ND } \\
(<0.1)\end{array}$ & 0.3 & $\begin{array}{l}\text { ND } \\
(<0.1)\end{array}$ & 8.7 & $\underset{(<0.1)}{\text { ND }}$ & 2.0 & $\begin{array}{l}\text { ND } \\
(<0.1)\end{array}$ & 1.1 & $\begin{array}{l}\text { Annual Avg.: } 80 \mu \mathrm{g} / \mathrm{m}^{3} \\
\text { (30.1 ppb) } \\
\text { 24-hour. max: } 365 \mu \mathrm{g} / \mathrm{m}^{3} \\
\text { (139.3 ppb) } \\
\text { 3-hour max.: } 1300 \mu \mathrm{g} / \mathrm{m}^{3} \\
\text { (500 ppb) }\end{array}$ & $\begin{array}{l}0.2 \mathrm{ppb}^{\mathrm{a}} \\
0.3-1.1 \mathrm{ppb}^{\mathrm{b}} \text { (Antarctica) } \\
0.02-0.2 \mathrm{ppb}^{\mathrm{c}} \text { (Antarctic } \\
\text { area) } \\
0.5-1.2 \mathrm{ppb}^{\mathrm{d}} \text { (King } \\
\text { George/Penguin Istands) }\end{array}$ & $\begin{array}{l}2.7-23 \mathrm{ppb}^{\mathrm{e}} \\
\text { (international) } \\
8.0-12 \mathrm{ppb}^{\mathrm{f}} \\
\text { (U.S.) }\end{array}$ \\
\hline $\begin{array}{l}\text { No } \\
(p p b)\end{array}$ & NA & NA & NA & NA & NA & NA & NA & NA & None & $0.2-2.0 \mathrm{ppb}^{\mathrm{a}}$ & - \\
\hline $\begin{array}{l}\mathrm{NO}_{2} \\
(p p b)\end{array}$ & NA & NA & NA & NA & NA & NA & NA & NA & $\begin{array}{l}\text { Annual Avg.: } 100 \mu \mathrm{g} / \mathrm{m}^{3} \\
\text { (52.4 ppb) }\end{array}$ & $0.5-4.0 \mathrm{ppb}^{\mathrm{a}}$ & $\begin{array}{l}22-28 \mathrm{ppb}^{\mathrm{f}} \\
\text { (U.S.) }\end{array}$ \\
\hline $\begin{array}{l}N O_{x} \\
(p p b)\end{array}$ & NA & NA & NA & NA & NA & NA & NA & NA & None & $\begin{array}{l}31 \text { ppb annual mean @ } \\
\text { Syowa Station, Antarctica }\end{array}$ & $40-80 \mathrm{ppb}^{\mathrm{g}}$ \\
\hline \multicolumn{12}{|l|}{ Sources: } \\
\hline \multicolumn{4}{|c|}{$\begin{array}{l}\text { a. Robinson and Robbins } 1969 \\
\text { b. Sterns } 1976 \\
\text { c. Nguyen Ba Cuong et al. } 1974 \\
\text { d. Molski et al. } 1981\end{array}$} & \multicolumn{5}{|c|}{$\begin{array}{l}\text { e. OECD } 1991 \\
\text { f. U.S. EPA } 1992 \\
\text { g. Wark and Warner } 1976 \\
\text { h. Khalil and Rasmussen } 1989\end{array}$} & & & \\
\hline
\end{tabular}


Table 3. Summary of gaseous air pollutant levels at Hut Point.

\begin{tabular}{|c|c|c|c|c|c|c|c|c|c|c|c|}
\hline \multirow[b]{2}{*}{ Gas type } & \multicolumn{2}{|c|}{ November } & \multicolumn{2}{|c|}{ December } & \multicolumn{2}{|c|}{ January } & \multicolumn{2}{|c|}{ February } & \multirow[b]{2}{*}{ U.S. NAAQS } & \multirow[b]{2}{*}{ Background } & \multirow[b]{2}{*}{ Urban } \\
\hline & Avg. & $\begin{array}{l}\text { Max } \\
\text { Hourly } \\
\text { Avg. }\end{array}$ & Avg. & $\begin{array}{l}\text { Max } \\
\text { Hourly } \\
\text { Avg. }\end{array}$ & Avg. & $\begin{array}{l}\text { Max } \\
\text { Hourly } \\
\text { Avg. }\end{array}$ & Avg. & $\begin{array}{l}\text { Max } \\
\text { Hourly } \\
\text { Avg. }\end{array}$ & & & \\
\hline \multirow[t]{2}{*}{$\begin{array}{c}\mathrm{CO} \\
(\mathrm{ppm})\end{array}$} & 0.1 & 0.3 & 0.1 & 0.4 & 0.2 & 0.5 & 0.2 & 0.3 & $\begin{array}{l}\text { 8-hour avg.: } 10 \mathrm{mg} / \mathrm{m}^{3} \\
(8.6 \mathrm{ppm})\end{array}$ & $\begin{array}{l}100 \mathrm{ppb}^{\mathrm{a}} \\
(0.1 \mathrm{ppm})\end{array}$ & $\begin{array}{l}1.1-1.6 \mathrm{ppm}^{\mathrm{f}} \\
\text { (U.S.) }\end{array}$ \\
\hline & & & & & & & & & $\begin{array}{l}\text { 1-hour max.: } 40 \mathrm{mg} / \mathrm{m}^{3} \\
\text { (34.9 ppm) }\end{array}$ & $\begin{array}{l}\text { 40-70 ppb@ } \\
\text { South Pole }\end{array}$ & \\
\hline \multirow[t]{4}{*}{$\begin{array}{l}\mathrm{SO}_{2} \\
(p p b)\end{array}$} & $\underset{(<0.1)}{N D}$ & 0.4 & $\begin{array}{l}\text { ND } \\
(<0.1)\end{array}$ & 0.8 & 0.1 & 5.6 & 0.1 & 4.3 & $\begin{array}{l}\text { Annual Avg.: } 80 \mu \mathrm{g} / \mathrm{m}^{3} \\
(30.1 \mathrm{ppb})\end{array}$ & $0.2 \mathrm{ppb}^{\mathrm{a}}$ & $\begin{array}{l}2.7-23 \mathrm{ppb}^{\mathrm{e}} \\
\text { (international) }\end{array}$ \\
\hline & & & & & & & & & $\begin{array}{l}\text { 24-hour. } \max : 365 \mu \mathrm{g} / \mathrm{m}^{3} \\
\text { (139.3 ppb) }\end{array}$ & (Antarctica) & $\begin{array}{l}\text { 8.0-12 } \mathrm{ppb}^{\mathrm{f}} \\
\text { (U.S.) }\end{array}$ \\
\hline & & & & & & & & & $\begin{array}{l}\text { 3-hour max.: } 1300 \mu \mathrm{g} / \mathrm{m}^{3} \\
(500 \mathrm{ppb})\end{array}$ & $\begin{array}{l}0.02-0.2 \mathrm{ppb}^{\mathrm{c}} \\
\text { (Antarctic area) }\end{array}$ & \\
\hline & & & & & & & & & & $\begin{array}{l}0.5-1.2 \mathrm{ppb}^{\mathrm{d}} \\
\text { (King George/ } \\
\text { Penguin Islands) }\end{array}$ & \\
\hline $\begin{array}{c}N O \\
(p p b)\end{array}$ & 0.7 & 26.3 & $\begin{array}{c}\text { ND } \\
(<0.03)\end{array}$ & 30.5 & 10.4 & 180.5 & 2.9 & 167.9 & None & $0.2-2.0 \mathrm{ppb}^{\mathrm{a}}$ & - \\
\hline $\begin{array}{l}\mathrm{NO}_{2} \\
(p p b)\end{array}$ & 6.7 & 21.0 & $\begin{array}{c}\text { ND } \\
(<0.03)\end{array}$ & 24.9 & 1.0 & 21.3 & 0.5 & 12.9 & $\begin{array}{l}\text { Annual Avg:: } 100 \mu \mathrm{g} / \mathrm{m}^{3} \\
\text { (52.4 ppb) }\end{array}$ & $0.5-4.0 \mathrm{ppb}^{\mathrm{a}}$ & $\begin{array}{l}\text { 22-28 ppbf } \\
\text { (U.S.) }\end{array}$ \\
\hline $\begin{array}{l}N O_{x} \\
(p p b)\end{array}$ & 4.2 & 41.0 & 0.2 & 41.5 & 12.6 & 186.4 & 5.0 & 181.8 & None & $\begin{array}{l}31 \mathrm{ppb} \text { annual } \\
\text { mean @ Syowa } \\
\text { Station, Antarctica }\end{array}$ & $40-80 \mathrm{ppb}^{\mathrm{g}}$ \\
\hline \multicolumn{12}{|l|}{ Sources: } \\
\hline \multicolumn{3}{|c|}{$\begin{array}{l}\text { a. Robinson and Robbins } 1969 \\
\text { b. Sterns } 1976 \\
\text { c. Nguyen Ba Cuong et al. } 1974 \\
\text { d. Molski et al. } 1981\end{array}$} & \multicolumn{4}{|c|}{$\begin{array}{l}\text { e. OECD } 1991 \\
\text { f. U.S. EPA } 1992 \\
\text { g. Wark and Warner } 1976 \\
\text { h. Khalil and Rasmussen } 1989\end{array}$} & & & & & \\
\hline
\end{tabular}


( $<0.1 \mathrm{ppb}$ ) for all 4 months of the austral summer, and the maximum hourly average value of $8.7 \mathrm{ppb}$ was observed in December.

Shortly after initial setup and calibration of the $\mathrm{NO}_{x}$ analyzer in early November at central McMurdo, the ozonator transformer failed. Unfortunately, the ozonator transformer was not one of the manufacturer's recommended spare parts on hand at McMurdo, and by the time a definite diagnosis of the cause of the instrument failure was performed and the replacement transformer received from the United States, the summer season was nearly over. Therefore, no $\mathrm{NO}_{\mathrm{x}}$ measurements for the duration of the 1993-1994 austral summer were obtained at this location. Consequently, it was decided that the entire set of gas analyzers at central McMurdo would not be relocated to 8-Site for 1 month as originally specified in the FY 1994 Ambient Air Monitoring Plan, but instead the two operable analyzers $\left(\mathrm{CO}\right.$ and $\left.\mathrm{SO}_{2}\right)$ would remain at central $\mathrm{McMurdo}$ for the duration of the monitoring period.

Seasonal data completeness for the Hut Point gas analyzers was quite good, ranging from 91.9\% for $\mathrm{CO}, 98.6 \%$ for $\mathrm{NO} / \mathrm{NO}_{2} / \mathrm{NO}_{x}$ and $99.2 \%$ for $\mathrm{SO}_{2 .}$. The central McMurdo set of analyzers experienced loss of most of the November data due to a data logger programming error during initial setup of the system in early November, and subsequent lesser data losses due to a faulty signal cable connection to the data logger, and other unknown failures of the data logger. The seasonal data completeness for the central McMurdo analyzers was $67.3 \%$ for the $\mathrm{CO}$ and $\mathrm{SO}_{2}$ data, and $0 \%$ for the $\mathrm{NO} / \mathrm{NO}_{2} / \mathrm{NO}_{\mathrm{x}}$ data.

At both locations, only about $1 \%$ of the hourly average data were deemed not representative due to calibration and zero/span check procedures. The reasons for data loss encountered at central McMurdo were due primarily to data logger programming error and poor cable communication to the data logger (76\% of lost data due to this cause). Twenty-three percent of the data lost was due to an unknown malfunction of the data logger or signal output from the analyzers. Future operators of these continuous gas analyzer and data logger systems need to pay special attention to ensure that the output signals from the analyzers are correctly and reliably captured electronically by the data logger.

PCDDs/PCDFs: Twelve 48-hour air samples from the McMurdo locale and one 121-hour sample from Black Island were collected for PCDD/PCDF analysis. The samples from the McMurdo area were collected simultaneously at the three local air monitoring locations on a monthly basis. Two field blanks were also submitted for analysis for quality assurance purposes. The sample collected at Black Island required the conversion of the ac-powered motor/blower in the PS-1 air sampler to a dc-powered motor/blower, since ac power was no longer available at this remote location.

Table 4 provides a summary of the PCDD/PCDF results for all samples collected. Although only one field blank was analyzed and reported by the analytical laboratory, the remaining quality assurance sample results satisfy the data quality requirements regarding method efficiency, identification criteria, and accuracy. Trace levels of PCDDs and PCDFs detected in the field blank (18.16/F-977) were used to correct the results for the air samples. The values reported in Table 4 have been blank-corrected. Table 4 also presents total PCDD and total PCDF values, toxicity equivalent factors (TEFs), and associated 2,3,7,8-TCDD equivalent concentrations (TEQs). Eight of the 13 samples indicated the presence of a few PCDD/PCDF compounds in the 
Table 4. Summary of FY 1994 PCDD/PCDF ambient air sample results from McMurdo, Antarctica.

\begin{tabular}{|c|c|c|c|c|c|c|c|c|c|}
\hline Date & $\begin{array}{c}\text { Total } \\
\text { sample } \\
\text { time (hr.) }\end{array}$ & Location & $\begin{array}{l}\text { Sample ID/ } \\
\text { lab ID }\end{array}$ & $\begin{array}{c}\text { Sample } \\
\text { volume } \\
\mathrm{m}^{3}\end{array}$ & $\begin{array}{c}\text { Avg. daily wind } \\
\text { direction/speed } \\
\text { (degrees @ knots) }\end{array}$ & \multicolumn{2}{|c|}{$\begin{array}{l}\text { PCDD/PCDF concentration } \\
\left(\mathrm{pg} / \mathrm{m}^{3}\right)\end{array}$} & $\mathrm{TEF}^{\mathrm{b}}$ & $\begin{array}{l}\mathrm{TEQ}^{\mathrm{c}} \\
\left(\mathrm{pg} / \mathrm{m}^{3}\right)\end{array}$ \\
\hline \multirow[t]{3}{*}{ 23-24 Nov 93} & 55.8 & 8-Site & $18.01 / F-965$ & 937 & $080 @ 09$ & $\mathrm{ND}^{\mathrm{e}}$ & & - & $\mathbf{0}$ \\
\hline & 48.0 & Hut Point & 18.11/F-973 & 552 & $080 @ 09$ & $\begin{array}{l}\text { OCDD } \\
\text { TOTAL PCDD: }\end{array}$ & $\begin{array}{l}0.06 \\
0.06\end{array}$ & 0.001 & $\begin{array}{r}\mathbf{0 . 0 0 0 0 6} \\
\text { TOTAL } \mathbf{0 . 0 0 0 0 6}\end{array}$ \\
\hline & 48.4 & $\begin{array}{l}\text { Central } \\
\text { McMurdo }\end{array}$ & $18.06 / F-970$ & 808 & $080 @ 09$ & $\begin{array}{l}\text { HpCDDs (TOTAL) } \\
\text { 1,2,3,4,6,7,8-HpCDD } \\
\text { OCDD } \\
\text { TOTAL PCDD: }\end{array}$ & $\begin{array}{l}0.02 \\
0.01 \\
0.10 \\
0.12\end{array}$ & $\begin{array}{l}0.01 \\
0.001\end{array}$ & $\begin{array}{r}\mathbf{0 . 0 0 0 1} \\
\mathbf{0 . 0 0 0 1} \\
\text { TOTAL } \mathbf{0 . 0 0 0 2}\end{array}$ \\
\hline 30 Nov-Dec 93 & 121.0 & Black Island & $18.17 / \mathrm{F}-975$ & 1263 & $N A^{f}$ & $\mathrm{ND}^{\mathrm{e}}$ & & - & $\mathbf{0}$ \\
\hline \multirow[t]{4}{*}{ 21-22 Dec 93} & 48.3 & 8-Site & $18.02 / F-967$ & 644 & $070 @ 12$ & $\mathrm{ND}^{\mathrm{e}}$ & & - & $\mathbf{0}$ \\
\hline & 48.0 & Hut Point & 18.12/F-974 & 579 & $070 @ 12$ & $\begin{array}{l}\text { OCDD } \\
\text { TOTAL PCDD: }\end{array}$ & $\begin{array}{l}0.09 \\
0.09\end{array}$ & 0.001 & $\begin{array}{r}0.00009 \\
\text { TOTAL } \mathbf{0 . 0 0 0 0 9}\end{array}$ \\
\hline & 48.0 & $\begin{array}{l}\text { Central } \\
\text { McMurdo }\end{array}$ & $18.07 / F-966$ & 776 & $070 @ 12$ & $\begin{array}{l}\text { HxCDDs (TOTAL) } \\
\text { HpCDDs (TOTAL) } \\
1,2,3,4,6,7,8-H p C D D \\
\text { OCDD } \\
\text { TOTAL PCDD: }\end{array}$ & $\begin{array}{l}0.02 \\
0.22 \\
0.07 \\
0.69 \\
0.93\end{array}$ & $\begin{array}{l}0.01 \\
0.001\end{array}$ & $\begin{array}{l}0.0007 \\
0.00069\end{array}$ \\
\hline & & & & & & $\begin{array}{l}\text { HxCDFs (TOTAL) } \\
\text { HpCDFs (TOTAL) } \\
\text { 1,2,3,4,6,7,8-HpCDF } \\
\text { OCDF } \\
\text { TOTAL PCDF: }\end{array}$ & $\begin{array}{l}0.04 \\
0.03 \\
0.009 \\
0.03 \\
0.10\end{array}$ & $\begin{array}{l}0.01 \\
0.001\end{array}$ & $\begin{array}{r}0.00009 \\
0.00003 \\
\text { TOTAL } \mathbf{0 . 0 0 1 5 1}\end{array}$ \\
\hline \multirow[t]{5}{*}{ 21-22 Jan 94} & 48.0 & 8-Site & $18.03 / F-969$ & 635 & $090 @ 10$ & $\mathrm{ND}^{\mathrm{e}}$ & & - & $\mathbf{0}$ \\
\hline & 47.4 & Hut Point & 18.13/F-979 & 542 & $090 @ 10$ & $\begin{array}{l}\text { OCDD } \\
\text { TOTAL PCDD: }\end{array}$ & $\begin{array}{l}0.05 \\
0.05\end{array}$ & 0.001 & $\begin{array}{r}\mathbf{0 . 0 0 0 0 5} \\
\text { TOTAL } \mathbf{0 . 0 0 0 0 5}\end{array}$ \\
\hline & 48.7 & Central & 18.01/F-971 & 828 & $090 @ 10$ & HxCDDs (TOTAL) & 0.04 & & \\
\hline & & & & & & $\begin{array}{l}\text { HpCDDs (TOTAL) } \\
1,2,3,4,6,7,8-\mathrm{HpCDD} \\
\text { OCDD } \\
\text { TOTAL PCDD: }\end{array}$ & $\begin{array}{l}0.13 \\
0.07 \\
0.40 \\
0.57\end{array}$ & $\begin{array}{l}0.01 \\
0.001\end{array}$ & $\begin{array}{l}0.0007 \\
0.0004\end{array}$ \\
\hline & & & & & & $\begin{array}{l}\text { HxCDFs (TOTAL) } \\
\text { HpCDFs (TOTAL) } \\
1,2,3,4,6,7,8-\mathrm{HpCDF} \\
\text { OCDF } \\
\text { TOTAL PCDF: }\end{array}$ & $\begin{array}{l}0.02 \\
0.04 \\
0.01 \\
0.02 \\
0.08\end{array}$ & $\begin{array}{l}0.01 \\
0.001\end{array}$ & $\begin{array}{r}\mathbf{0 . 0 0 0 1} \\
\mathbf{0 . 0 0 0 0 2} \\
\text { TOTAL } \mathbf{0 . 0 0 1 2 2}\end{array}$ \\
\hline
\end{tabular}


Table 4. (continued).

\begin{tabular}{|c|c|c|c|c|c|c|c|c|c|}
\hline Date & $\begin{array}{c}\text { Total } \\
\text { sample } \\
\text { time (hr.) }\end{array}$ & Location & $\begin{array}{l}\text { Sample ID/ } \\
\text { lab ID }\end{array}$ & $\begin{array}{c}\text { Sample } \\
\text { volume std } \\
\text { m }^{3}\end{array}$ & $\begin{array}{l}\text { Avg. daily wind } \\
\text { direction/speed } \\
\text { (degrees@ @nots) }\end{array}$ & \multicolumn{2}{|c|}{$\begin{array}{l}\text { PCDD/PCDF concentration } \\
\left(\mathrm{pg} / \mathrm{m}^{3}\right)\end{array}$} & $\mathrm{TEF}^{\mathrm{b}}$ & $\underset{\left(\mathrm{pg} / \mathrm{m}^{3}\right)}{\mathrm{TEQ}^{\mathrm{c}}}$ \\
\hline \multirow[t]{4}{*}{ 01-02 Feb 94} & 47.5 & 8-Site & $18.04 / F-986$ & 635 & $050 @ 10$ & $\mathrm{ND}^{\mathrm{e}}$ & & - & $\mathbf{0}$ \\
\hline & 46.7 & Hut Point & 18.14/F-978 & 554 & $050 @ 10$ & $\begin{array}{l}\text { OCDD } \\
\text { TOTAL PCDD: }\end{array}$ & $\begin{array}{l}0.04 \\
0.04\end{array}$ & 0.001 & $\begin{array}{r}\mathbf{0 . 0 0 0 0 4} \\
\text { TOTAL } \mathbf{0 . 0 0 0 0 4}\end{array}$ \\
\hline & & $\begin{array}{l}\text { Central } \\
\text { McMurdo }\end{array}$ & 18.09/F-972 & 814 & $050 @ 10$ & $\begin{array}{l}\text { HpCDDs (TOTAL) } \\
1,2,3,4,6,7,8-H p C D D \\
\text { OCDD } \\
\text { TOTAL PCDD: }\end{array}$ & $\begin{array}{l}0.03 \\
0.02 \\
0.11 \\
0.14\end{array}$ & $\begin{array}{l}0.01 \\
0.001\end{array}$ & $\begin{array}{l}0.0002 \\
0.00011\end{array}$ \\
\hline & & & & & & $\begin{array}{l}\text { OCDF } \\
\text { TOTAL PCDF }\end{array}$ & $\begin{array}{l}0.006 \\
0.006\end{array}$ & 0.001 & $\begin{array}{r}\mathbf{0 . 0 0 0 0 0 6} \\
\text { TOTAL } \mathbf{0 . 0 0 0 3 1 6}\end{array}$ \\
\hline 02 Feb 94 & & $\begin{array}{l}\text { Field Blank } \\
\text { @ Central } \\
\text { McMurdo }\end{array}$ & 18.16/F-977 & 736 (avg.) & NA & $\begin{array}{l}\text { HxCDDS (Total) } \\
\text { HpCDDS (Total) } \\
\text { 1,2,3,4,6,7,8-HpCDD } \\
\text { OCDD } \\
\text { TCDFs (Total) } \\
\text { 2,3,7,8-TCDF } \\
\text { HxCDFs (Total) } \\
\text { HPCDFs (Total) } \\
\text { 1,2,3,4,6,7,8-HpCDF }\end{array}$ & $\begin{array}{l}0.04 \\
0.06 \\
0.03 \\
0.09 \\
0.12 \\
0.03 \\
0.03 \\
0.02 \\
0.009\end{array}$ & - & NA \\
\hline
\end{tabular}

a. Values reported are corrected for method or field blank concentrations.

b. Toxicity Equivalent Factor (TEF), Reference: U.S. EPA (EPA/625/3-89/016) March 1989.

c. Toxicity Equivalent (TEQ) is the equivalent concentration of 2,3,7,8-TCDD.

d. Method or field blank concentrations used to correct sample results. Two sets of samples and corresponding blanks.

e. Not Detected (ND) indicates compound was not detected or was detected at or below associated maximum blank concentrations.

f. Not Available or Not Applicable (NA). 
sub-pg/m $\mathrm{m}^{3}$ range. The Black Island and 8-Site sample results indicate no detectable PCDD/PCDF compounds present at these locations during the FY 1994 monitoring periods. The four samples from central McMurdo demonstrated the highest concentrations and most number of congeners, as compared to the sample results from Hut Point, where only the octachlorinated dioxin (OCDD) congener was detected.

The concentrations of the few congeners detected at central McMurdo and Hut Point were in most cases very near the method detection limit. The concentrations and number of congeners measured in FY 1994 at these locations were reduced from measurements performed in FY 1993 (Lugar 1993d), and this reduction is likely attributable to the cessation of selected solid waste incineration in March 1993. Additionally, those congener types detected in FY 1994 were all previously detected in FY 1993, indicating that there are combustion sources (power plant, vehicles, heating furnaces, etc.) at McMurdo other than the solid waste incinerator that contribute PCDD/PCDF compounds to the ambient air. During both years, the most frequently detected congeners (and the congeners usually detected at the highest concentration) were OCDD and heptachlorodioxin (HpCDD). Figures 8 and 9 provide graphical profiles of PCDD/PCDF congeners detected during FY 1994 at central McMurdo and Hut Point.

The FY 1994 average of total PCDD and total PCDF levels of the four central McMurdo samples was 0.44 and $0.049 \mathrm{pg} / \mathrm{m}^{3}$, respectively. The total PCDD average for FY 1994 is slightly lower than the prior-year average of $0.61 \mathrm{pg} / \mathrm{m}^{3}$, while the total PCDF average for FY 1994 was an order of magnitude lower than the prior year average of $0.56 \mathrm{pg} / \mathrm{m}^{3}$. The reduction in the average concentration of total PCDF levels between FY 1993 and FY 1994 is postulated to be related to the discontinuation of solid waste incineration. Average total PCDD at Hut Point was identical for both years; however, during FY 1994, no PCDF compounds were measured at Hut Point, as compared to trace levels $\left(0.19 \mathrm{pg} / \mathrm{m}^{3}\right)$ of total PCDFs measured in FY 1993 during incineration. These average total PCDD and total PCDF levels are comparable to levels measured by other researchers in suburban and rural areas (see Table 5).

The FY 1994 average TEQ concentration for the four central McMurdo samples was $0.0007815 \mathrm{pg} / \mathrm{m}^{3}(2,3,7,8-T C D D$ equivalents), notably lower than the FY 1993 average of $0.0153 \mathrm{pg} / \mathrm{m}^{3}$; and well below the State of Connecticut ambient air standard of $1.0 \mathrm{pg} / \mathrm{m}^{3}$ expressed as 2,3,7,8-TCDD equivalents (see Figure 10). Note that presently, there are no EPA national ambient air quality standards for PCDD/PCDF compounds. 
(a) November 23-24, 1993

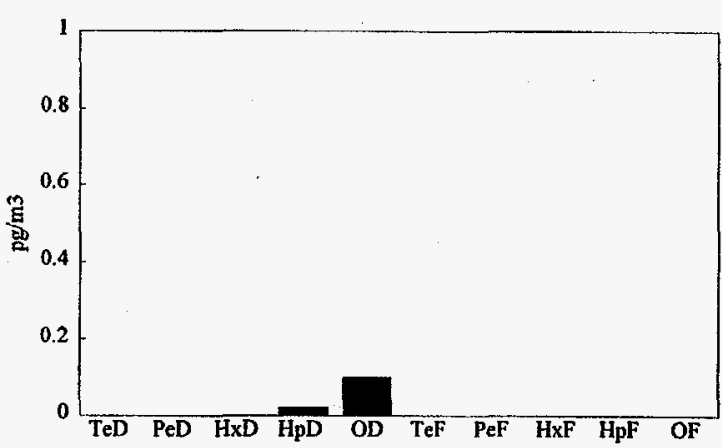

๙ั

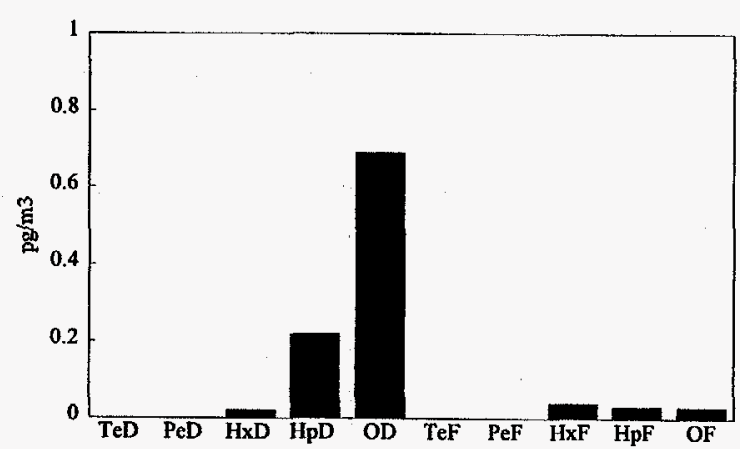

(c) January 21-22, 1994

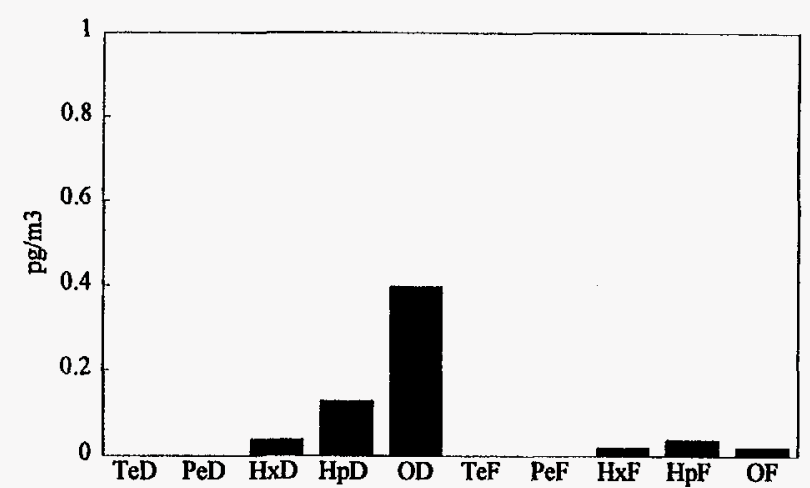

(d) February 01-02, 1994

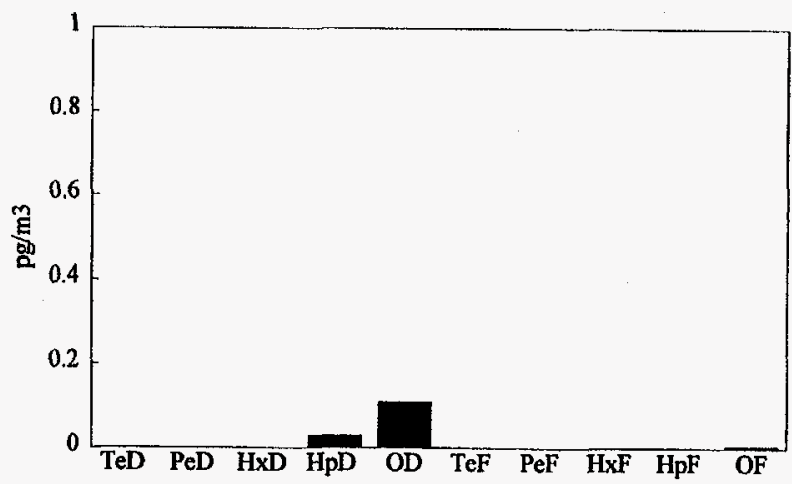

Figure 8. Profile of PCDD/PCDF congeners detected during 1993-1994 austral summer at central McMurdo, Antarctica. 

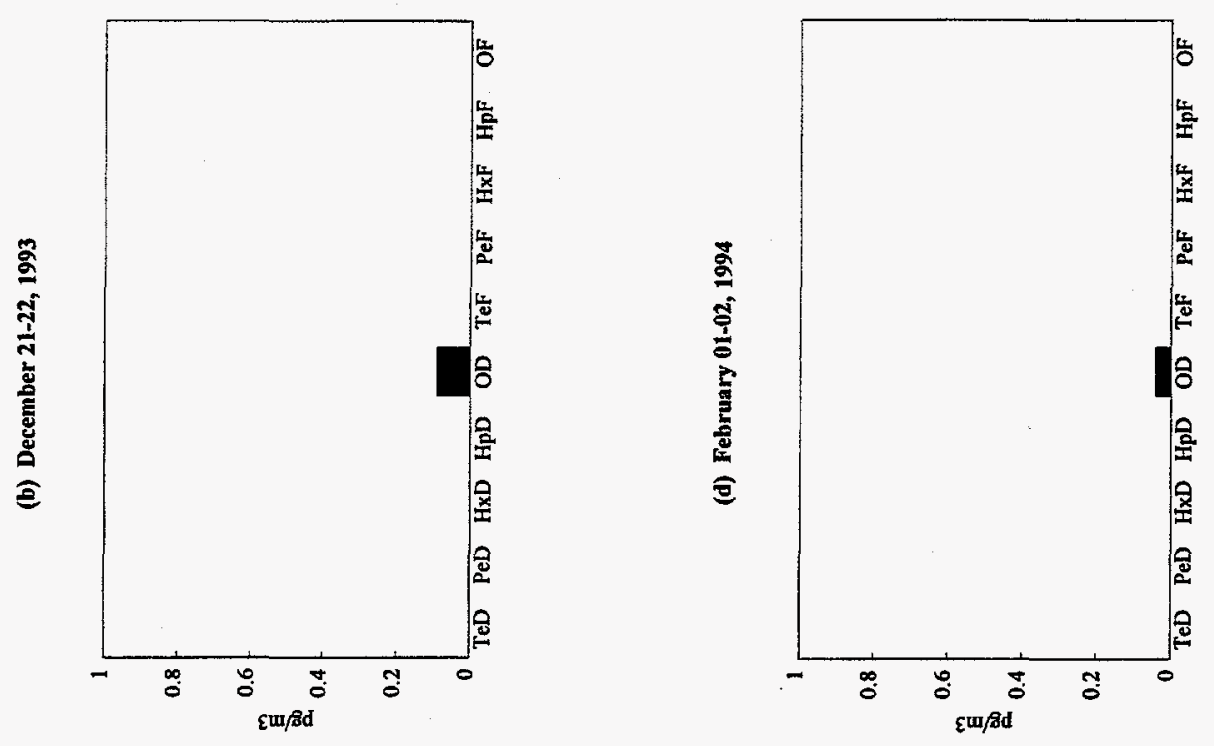

葛
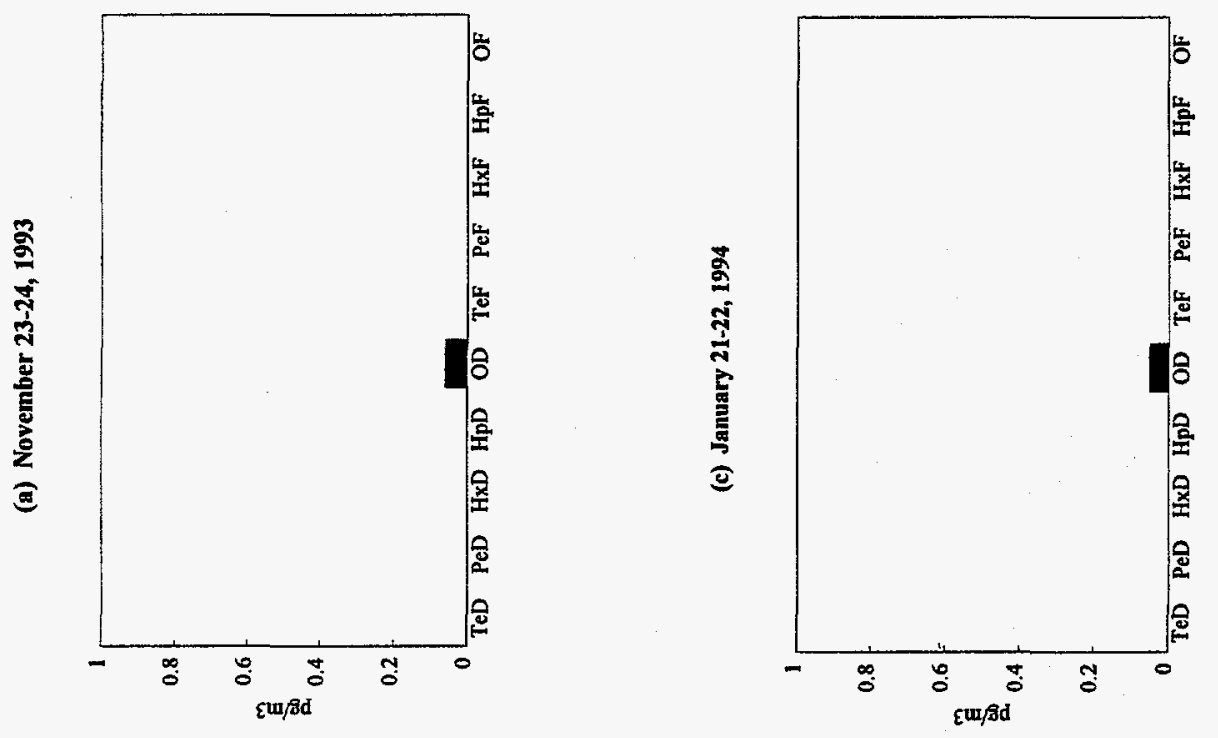

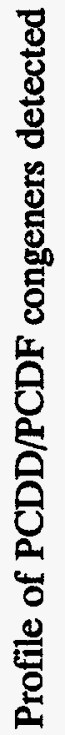

禹 
Table 5. Comparison of Antarctica ambient air concentration of PCDD/PCDF with those of other locations. Antarctic results are in boldface type.

\begin{tabular}{|c|c|c|}
\hline Location/type & $\begin{array}{c}\text { Total PCDF } \\
\left(\mathrm{pg} / \mathrm{m}^{3}\right)\end{array}$ & $\begin{array}{c}\text { Total PCDD } \\
\left(\mathrm{pg} / \mathrm{m}^{3}\right)\end{array}$ \\
\hline Industrial (Hamburg, Germany) $^{\mathbf{a}}$ & $\overline{15}$ & 13 \\
\hline Auto-tunnel (Hamburg, Germany) ${ }^{b}$ & 13 & 16 \\
\hline Industrial $^{c}$ & 10 & 9 \\
\hline Urband & 8.8 & 8.6 \\
\hline Urban \& industrial (Nordhein-Westfalen, Germany) $^{e}$ & 5.5 & 3.2 \\
\hline Urban (Indianapolis, Indiana USA) ${ }^{f}$ & 2.6 & 2.5 \\
\hline Suburban (Hamburg, Germany) ${ }^{g}$ & 0.74 & 1.8 \\
\hline Suburban (Bloomington, Indiana USA) ${ }^{\mathrm{h}}$ & 0.63 & 1.2 \\
\hline Suburban $^{\mathrm{i}}$ & 0.50 & 1.0 \\
\hline Suburban (Research Triangle Park, North Carolina USA) & 1.10 & 0.56 \\
\hline Rural (Trout Lake, Wisconsin USA) ${ }^{\mathbf{k}}$ & 0.18 & 0.24 \\
\hline Central McMurdo, Antarctica FY $1993^{1} / \mathrm{FY} 1994^{\mathrm{m}}$ & $0.56 / 0.049$ & $0.61 / 0.44$ \\
\hline Hut Point, Antarctica ${ }^{m}$ FY $1993^{n} /$ FY $1994^{\circ}$ & $0.19 / N D$ & 0.0610 .06 \\
\hline 8-Site Antarctica FY 1993P/FY 1994p & NDND & ND/ND \\
\hline Black Island, Antarctica FY 1993\%/FY 19949 & $\mathbf{N D} / \mathbf{N D}$ & ND/ND \\
\hline \multicolumn{3}{|l|}{ a. Average of sites 6 and 7 from Tables $2-7$ in Rappe et al. (1988). } \\
\hline \multicolumn{3}{|l|}{ b. Average of site 8 from Tables $2-7$ in Rappe et al. (1988). } \\
\hline \multicolumn{3}{|l|}{ c. Average of CAM site from Table 2 in Smith et al. (1988). } \\
\hline \multicolumn{3}{|l|}{ d. Determined from Figure 4 in Nakano et al. (1987). } \\
\hline \multicolumn{3}{|l|}{ e. From Table 9 in Buck and Kirschmer (1986). } \\
\hline \multicolumn{3}{|l|}{ f. From Table 5-4 in Hites. (1991). } \\
\hline \multirow{2}{*}{\multicolumn{3}{|c|}{$\begin{array}{l}\text { g. Average of sites } 1 \text { and } 2 \text { from Tables } 2-7 \text { in Rappe et al. (1988). } \\
\text { h. From Table 5-4 in Hites. (1991). }\end{array}$}} \\
\hline & & \\
\hline \multicolumn{3}{|l|}{ i. Average of HRB site from Table 2 in Smith et al. (1988). } \\
\hline \multicolumn{3}{|l|}{ j. From Table 6 in Harless, et al. (1992). } \\
\hline \multicolumn{3}{|l|}{ k. From Table $5-4$ in Hites. $(1991)$} \\
\hline \multicolumn{3}{|l|}{ 1. Average of five samples, total PCDF detected in only two samples. } \\
\hline \multicolumn{3}{|c|}{$\begin{array}{l}\text { m. Average of four samples, total PCDF detected in three samples, total PCDD detected in four } \\
\text { samples. }\end{array}$} \\
\hline \multicolumn{3}{|c|}{$\begin{array}{l}\text { n. Average of five samples, total PCDF detected in two samples, total PCDD detected in three } \\
\text { samples. }\end{array}$} \\
\hline \multirow{2}{*}{\multicolumn{3}{|c|}{$\begin{array}{l}\text { o. Average of four samples, total PCDF not detected, total PCDD detected in four samples. } \\
\text { p. Not detected in three samples analyzed, detection limit dependent on analytical batch, specific } \\
\text { congeners. }\end{array}$}} \\
\hline & & \\
\hline \multicolumn{3}{|c|}{ q. Not detected in single sample, detection limit dependent on analytical batch and specific congeners. } \\
\hline & & \\
\hline
\end{tabular}




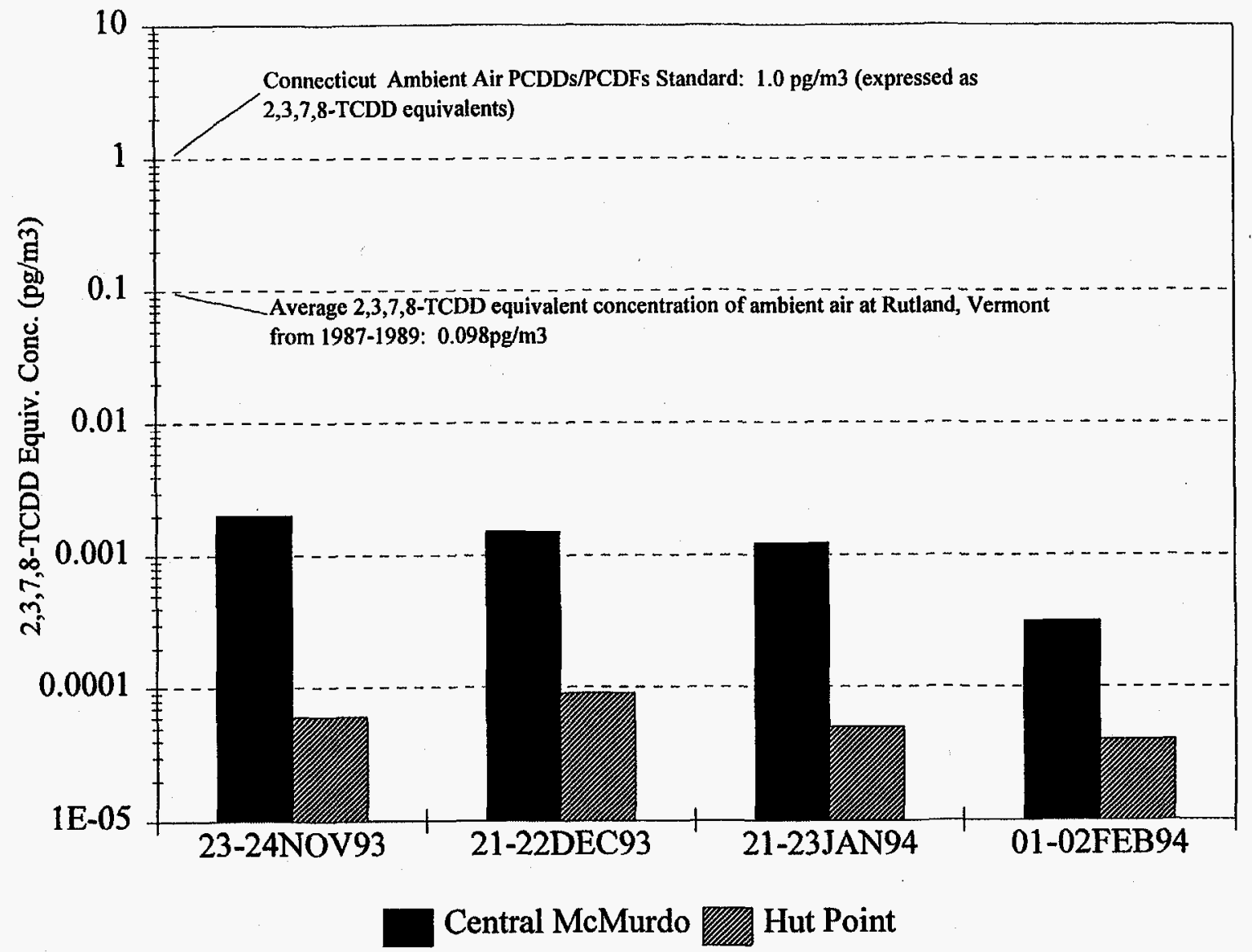

Figure 10. PCDD/PCDF concentration (expressed as 2, 3, 7, 8-TCDD equivalents) in ambient air at McMurdo, Antarctica during the 1993-1994 austral summer. 


\section{CONCLUSIONS}

The addition of the FY 1994 ambient air monitoring data to the initial baseline data collected in FY 1993 provides a larger and more reliable set of ambient air data for the McMurdo locale. These data confirm that the impact of McMurdo operations on local air quality can be qualitatively and quantitatively measured. The impact of these operations on air quality is negligible, as local ambient air pollutant concentrations are well below applicable U.S. ambient air quality standards, and, in many cases, near the level of detection of the measurement instruments. The data indicate that there are sources of PCDD/PCDF emissions at McMurdo other than the (discontinued) incineration of selected solid waste; however, the impact of waste incineration on PCDD/PCDF air concentration and congener variety was observed. These data are useful for assessing the impact of McMurdo operations on local air quality, and will aid in future evaluation of the impact of changes in station population, fuel consumption, and station operations.

Future studies of metal emissions should consider employing longer sample time periods, ultra clean sampling techniques, and ultra pure air filters. The use of source apportionment study methodologies and procedures would optimize further research efforts in the area of metal emissions. Future PM-10 monitoring efforts should consider utilizing samplers with brushless motors, thereby minimizing maintenance downtime and the costs associated with frequent brush replacement. Future operators of the continuous gas analyzers need to pay close attention to data logger programming, analyzer signal input connections, and data downloading to ensure data completeness. 


\section{REFERENCES}

Code of Federal Regulations, 40 CFR 58, Appendix D, "Network Design for State and Local Air Monitoring Stations (SLAMS) and National Air Monitoring Stations (NAMS)," July 1989.

Code of Federal Regulations, 40 CFR 50, Appendix J, "Reference Method for the Determination of Particulate Matter as PM-10 in the Atmosphere," Office of the Federal Register, July 1991.

EPA (U.S. Environmental Protection Agency), 1977. Quality Assurance Handbook for Air Pollution Measurement Systems, Volume II - Ambient Air Specific Methods. Research Triangle Park, NC. EPA-600/4-77-027a, May 1977.

EPA 1986. Test Methods for Evaluating Solid Waste, SW-846 third edition, EPA Office of Solid Waste and Emergency Response, November 1986, including update I to the third edition, July 1993.

EPA, 1992. National Air Quality Trends and Emissions Trends Report, 1991. U.S. EPA Office of Air Quality Planning and Standards, Research Triangle Park, NC. EPA/450-R-92-001, October 1992.

Harless, R. L., et.al, 1992. "Evaluation of Sampling and Analysis Method for Determination of Polyhalogenated Dibenzo-p-Dioxins and Dibenzofurans in Ambient Air", Chemosphere, Vol. 25, Nos. 7-10, pp. 1317-1322, Oct.-Nov., 1992.

Khalil, M.A.K, and R.A. Rasmussen, 1989. "Seasonal Cycles of Hydrogen and Carbon Monoxide in the Polar Regions: Opposite Phase Relationships," Antarctic Journal, 1989 Review.

Lugar, Robert M., 1992. FY-1993 Ambient Air Monitoring Plan for McMurdo Station, Antarctica. Prepared for the National Science Foundation Division of Polar Programs. EG\&G Idaho Inc., Idaho Falls, ID 83415, Sept. 1992.

Lugar, Robert M., 1993a. FY-1994 Ambient Air Monitoring Plan for McMurdo Station, Antarctica. Prepared for National Science Foundation Division of Polar Programs. EG\&G Idaho Inc., Idaho Falls, ID 83415. November 1993.

Lugar, Robert M., 1993b. Results of PM-10 and TSP Monitoring at McMurdo Station, Antarctica. Prepared for National Science Foundation Division of Polar Programs. EG\&G Idaho Inc., Idaho Falls, ID 83415. May 1993.

Lugar, Robert M., 1993c. Results of $\mathrm{SO}_{2}$ Nox, and $\mathrm{CO}$ Monitoring at McMurdo Station, Antarctica. Prepared for National Science Foundation Division of Polar Programs. EG\&G Idaho Inc., Idaho Falls, ID 83415. May 1993. 
Lugar, Robert M., 1993d. Results of Monitoring for PCDDs and PCDFs in Ambient Air at McMurdo Station, Antarctica. Prepared for National Science Foundation Division of Polar Programs. EG\&G Idaho Inc., Idaho Falls, ID 83415. September 1993.

Lugar, Robert M., 1994. Results of TSP Metals Monitoring at McMurdo Station, Antarctica. Prepared for National Science Foundation Division of Polar Programs, EGG-CIET-11270. EG\&G Idaho Inc., Idaho Falls, ID 83415. April 1994.

Molski, Boguslaw, Andrzej Bytnerowicz, and Wojciech Dmuchowski, 1981. "Air Pollution with Sulfur Dioxide and Fluorine Compounds in the Vicinity of Arctowski Station, King George Island, South Shetland Islands," Polish Polar Research, 2/1-2/87-93/1981.

NSF (National Science Foundation), 1989. Implementation of the National Science Foundation's Strategy for Compliance with Environmental Law in Antarctica. National Science Foundation, Washington, D.C. 19 pp. 1989.

NSF, 1991. Supplemental Environmental Impact Statement for the United States Antarctic Program. National Science Foundation, Washington, D.C. October 1991.

Nyguyen Ba Cuong, Bernard Bonsang, and Gerard Lambert, 1974. "The Atmospheric Concentration of Sulfur Dioxide and Sulfate Aerosols Over Antarctic, Subantarctic Areas and Oceans," Tellus XXXVI (1974), 1-2.

OECD (Organization for Economic Cooperation and Development), 1991. The State of the Environment. Paris, France, 1991.

Robinson, E. and R.C. Robbins, 1969. "Sources, Abundances, and Fate of Atmospheric Pollutants," Stanford Research Institute, Report SRI Project PR-6755, February 1968. Supplemental Report, June 1969.

Sterns, A.S. (Ed.) 1976. Air Pollution. Academic Press, New York.

Wark, Kenneth, and Cecil F. Warner, 1976. Air Pollution, Its Origin and Control. Harper \& Row Publishers, New York, New York. 1976. 


\section{Appendix A}

1993-1994 Austral Summer Hourly Average $\mathrm{CO}, \mathrm{SO}_{2}$, and $\mathrm{NO}_{x}$ concentrations at

Hut Point and Central McMurdo, Antarctica 
A-2 


\section{Central McMurdo Hourly Avg. CO Levels}

November 1993

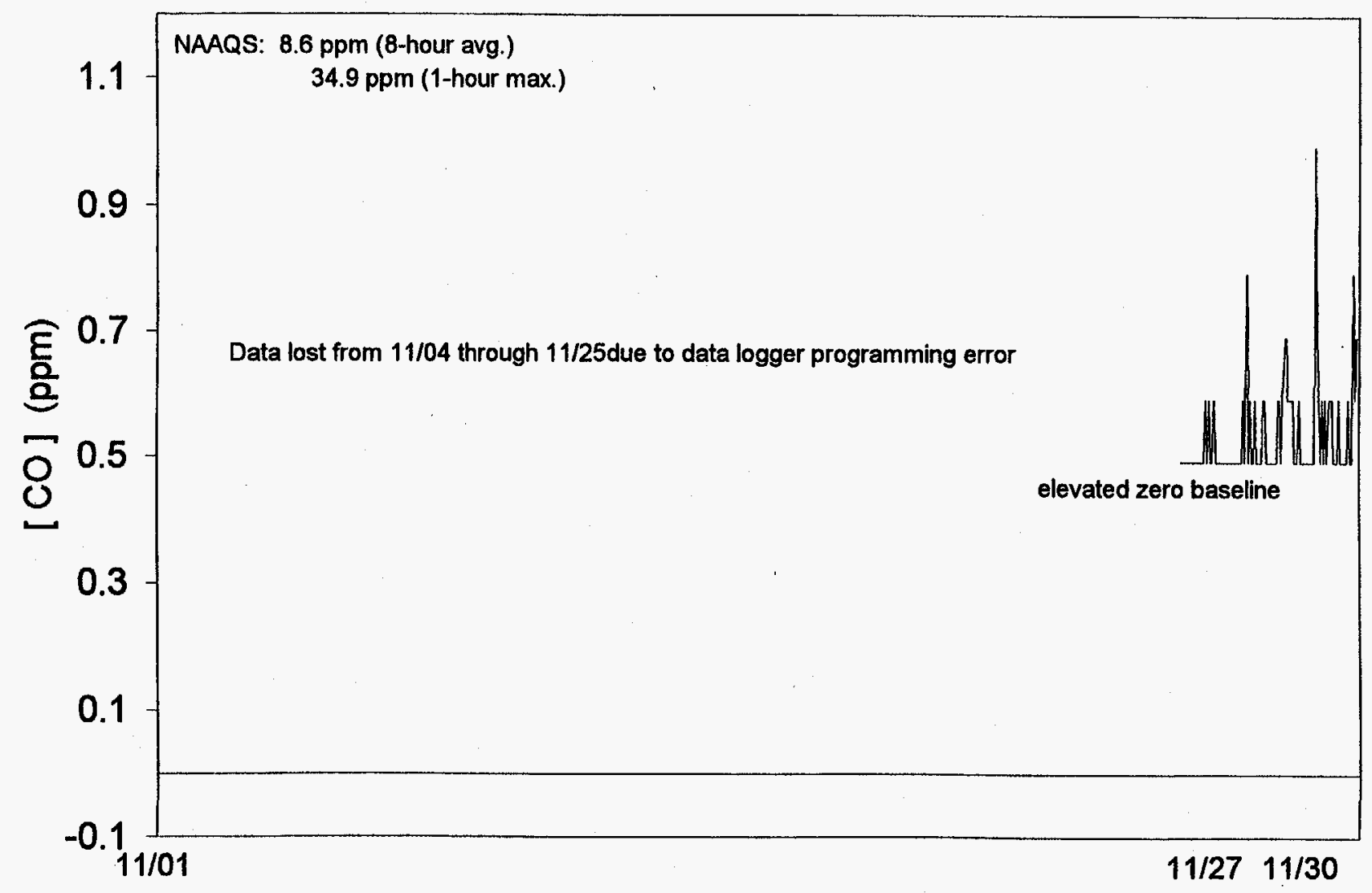




\section{Central McMurdo Hourly Avg. CO Levels}

December 1993

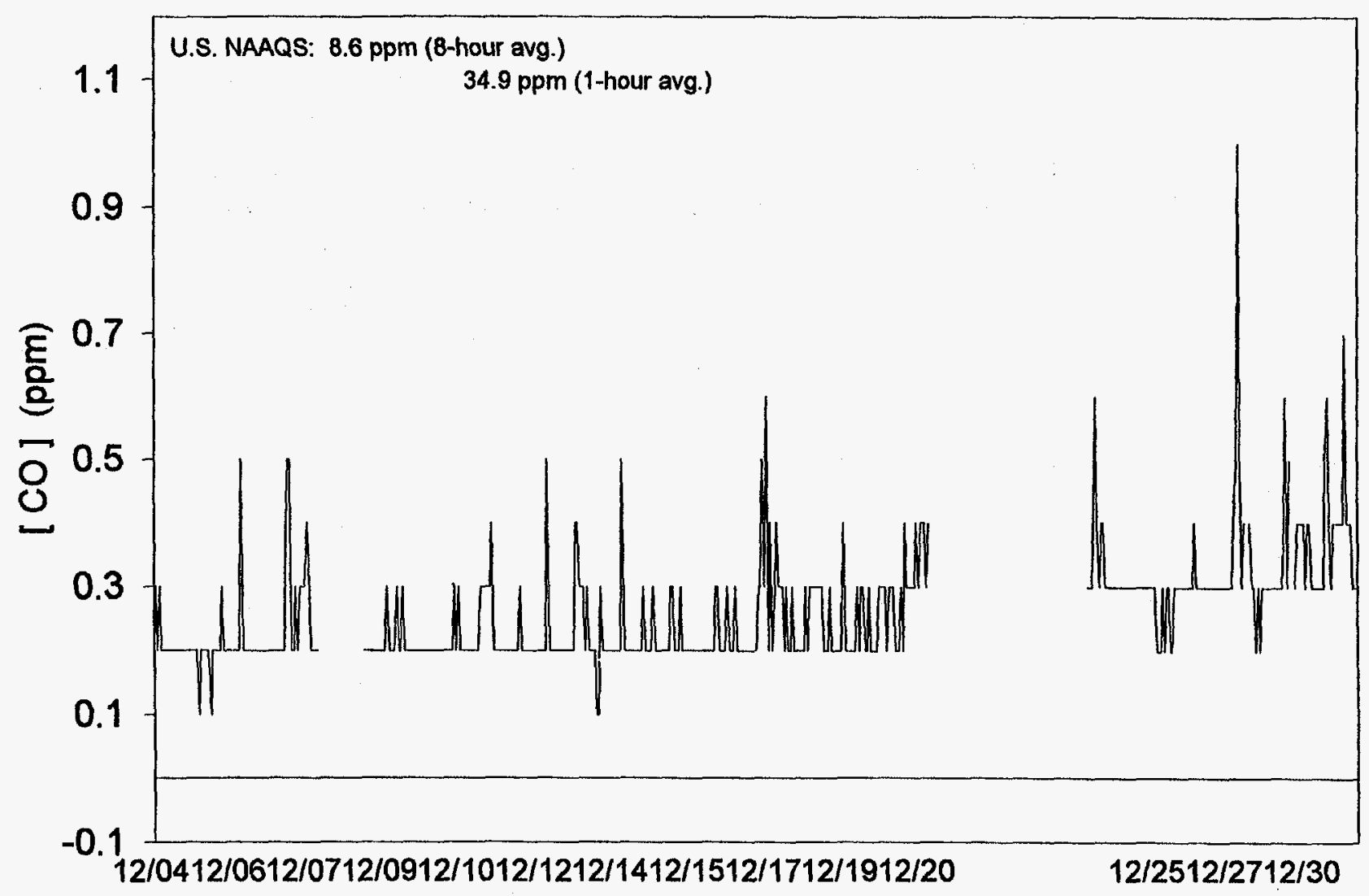




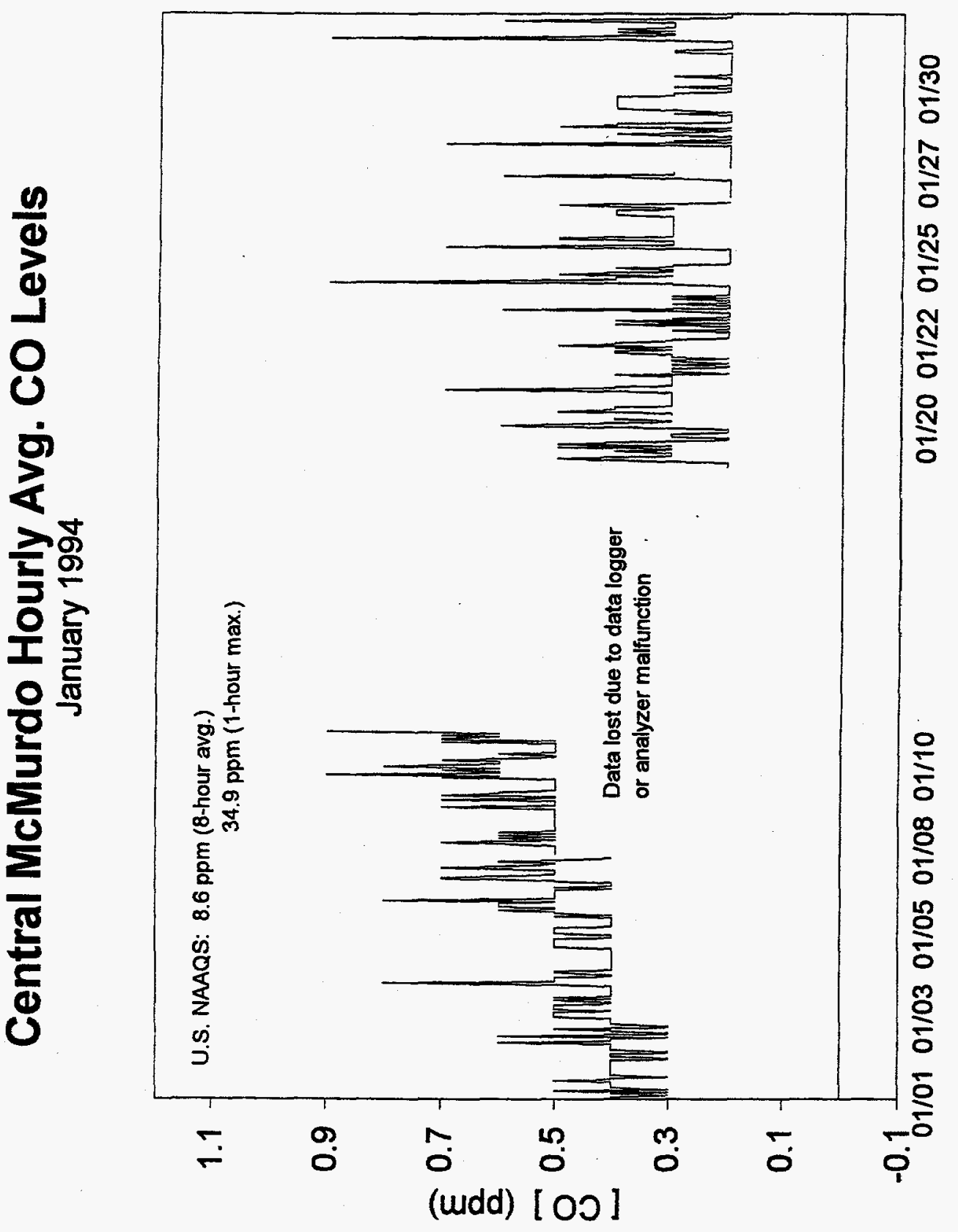




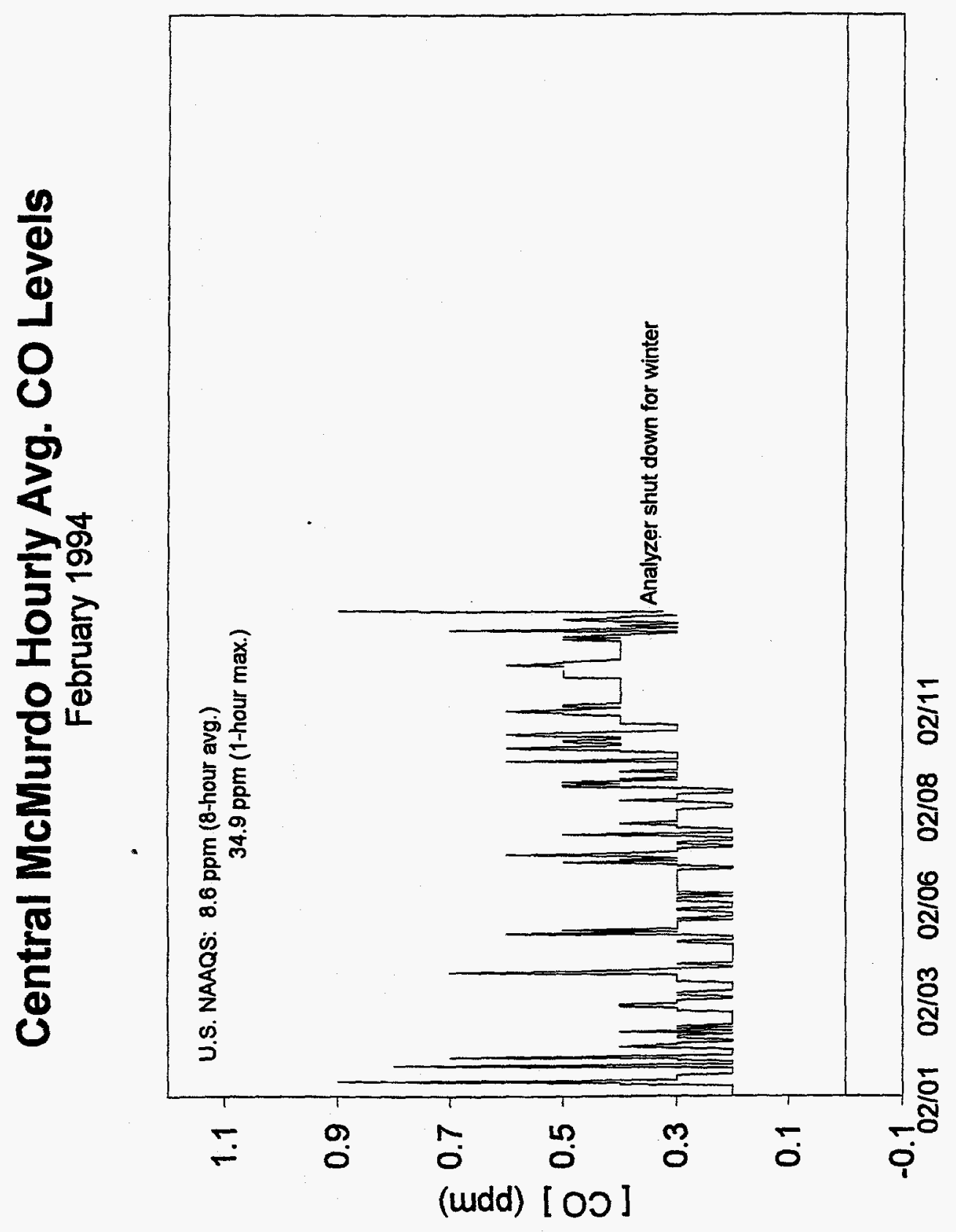




\section{Central McMurdo Hourly Avg. SO2 Levels}

November 1993

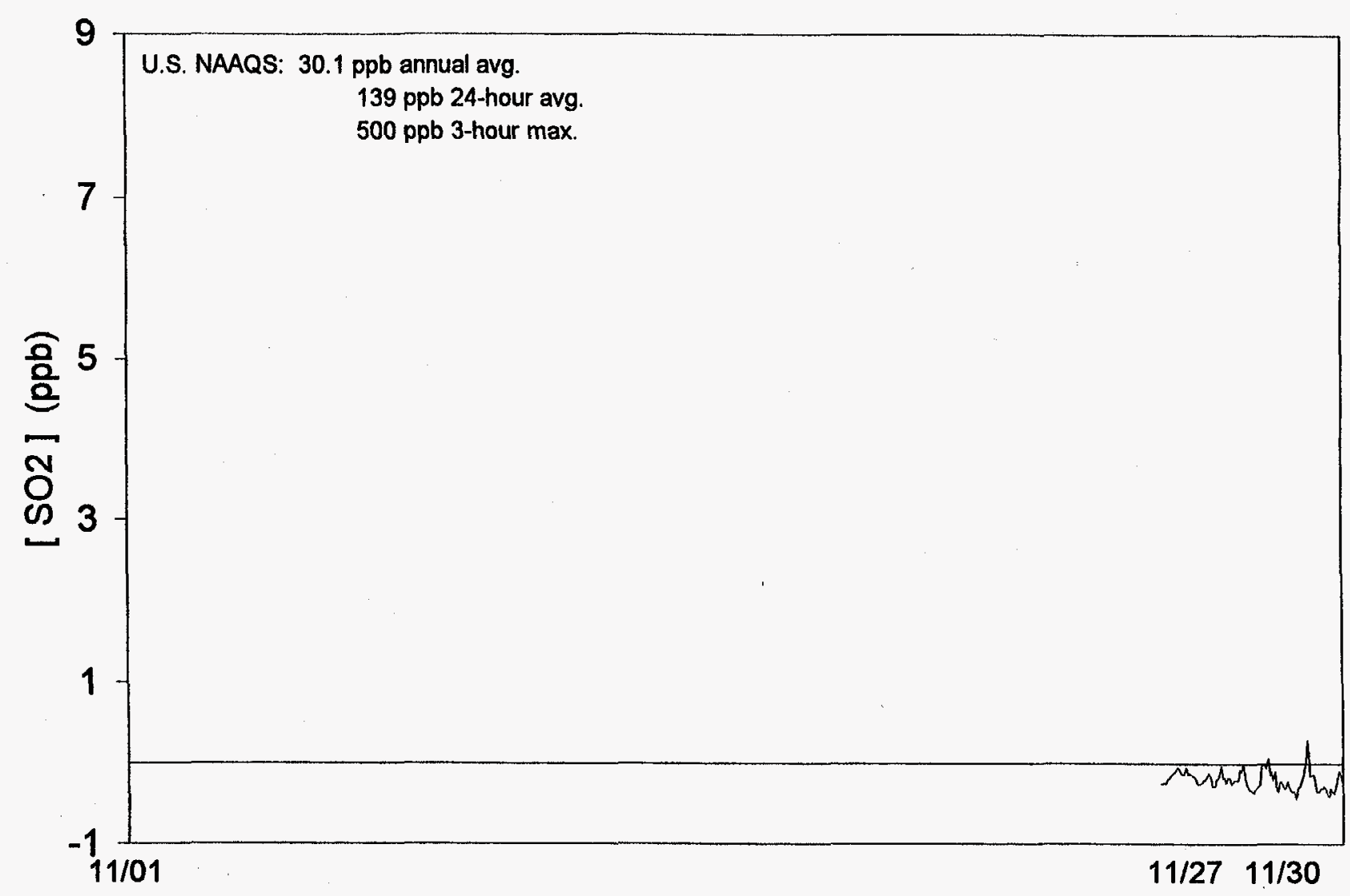




\section{Central McMurdo Hourly Avg. SO2 Levels}

December 1993

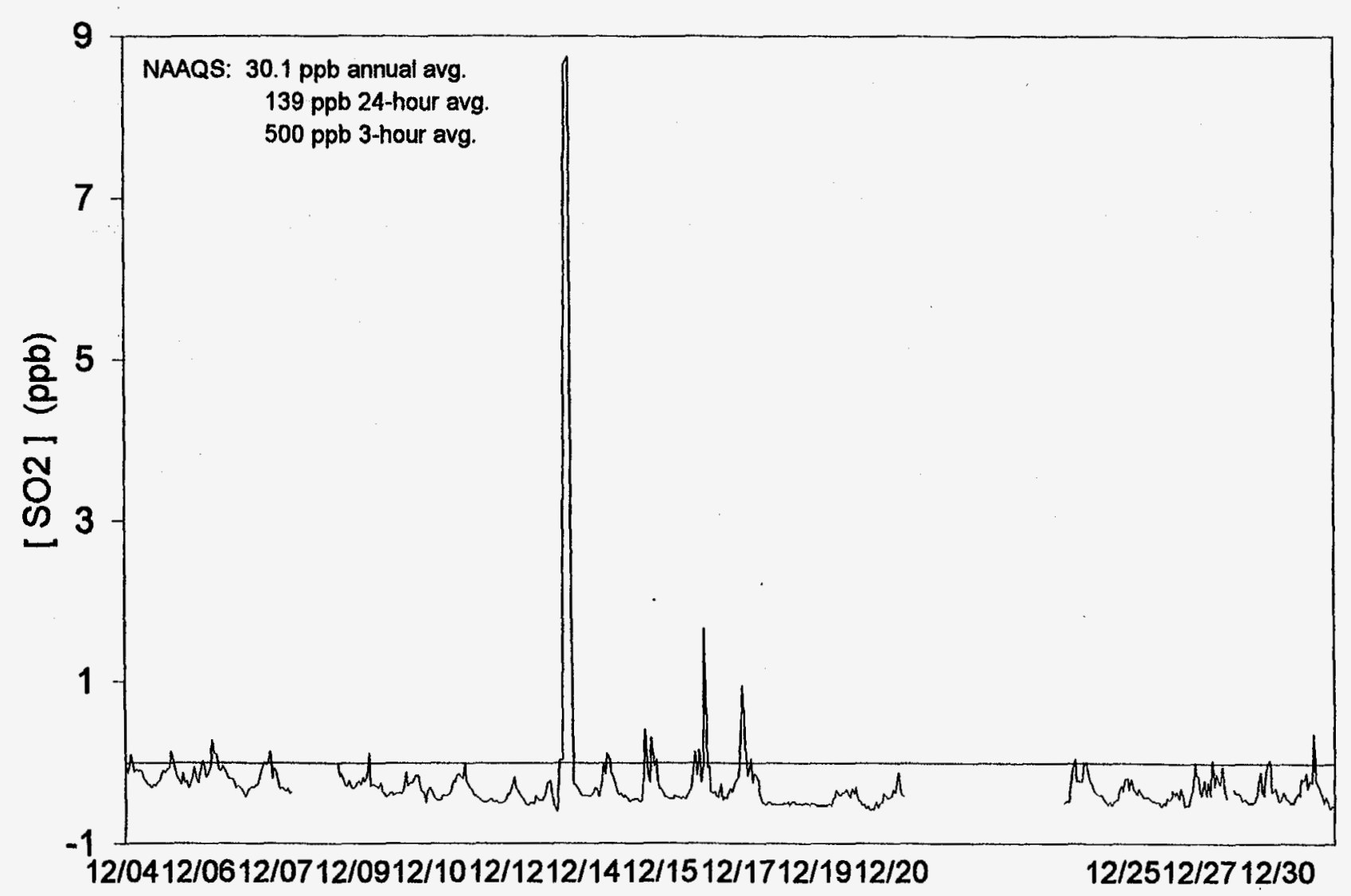




\section{Central McMurdo Hourly Avg. SO2 Levels}

January 1994

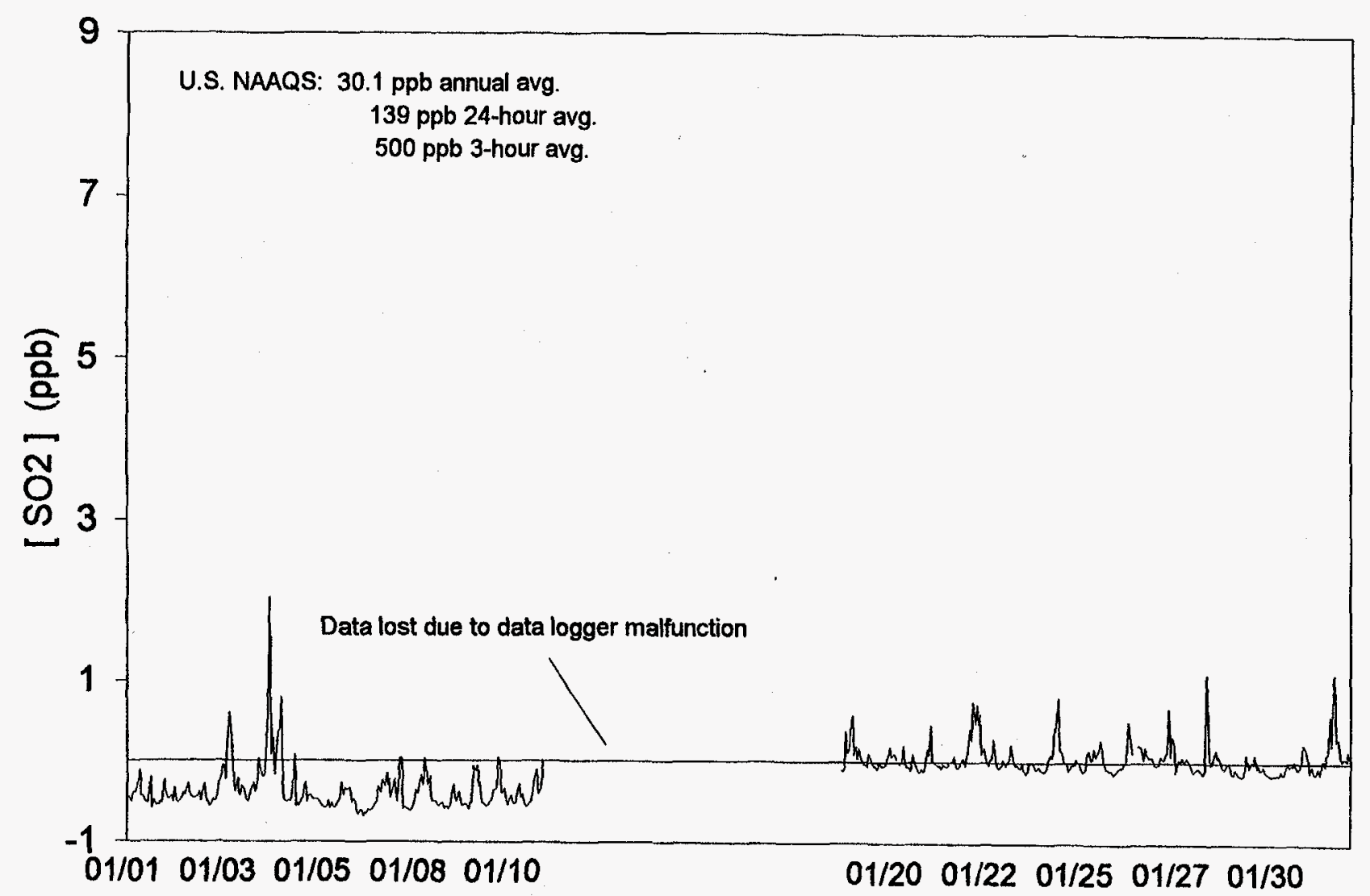




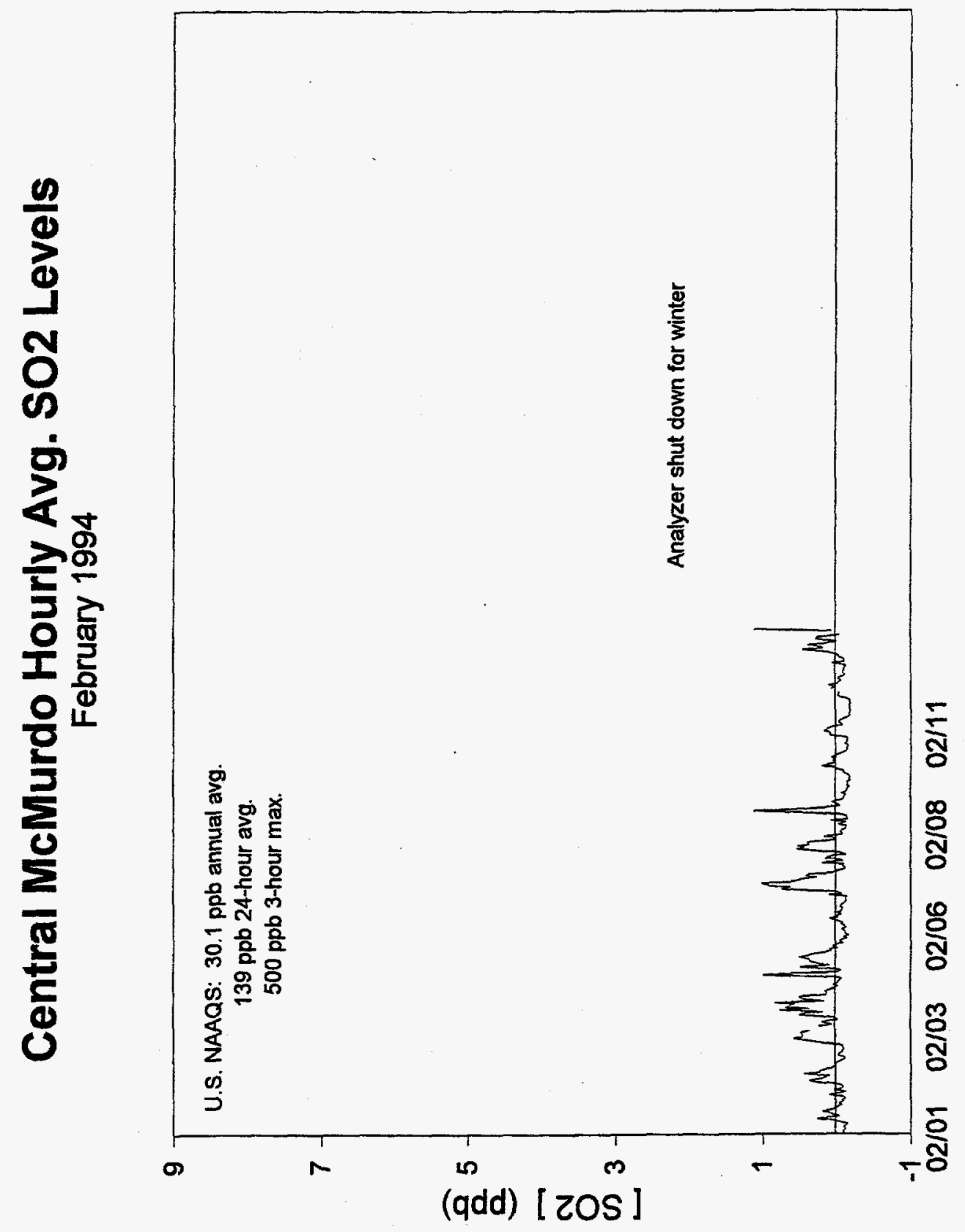




\section{Hut Point Hourly Average CO Levels}

November 1993

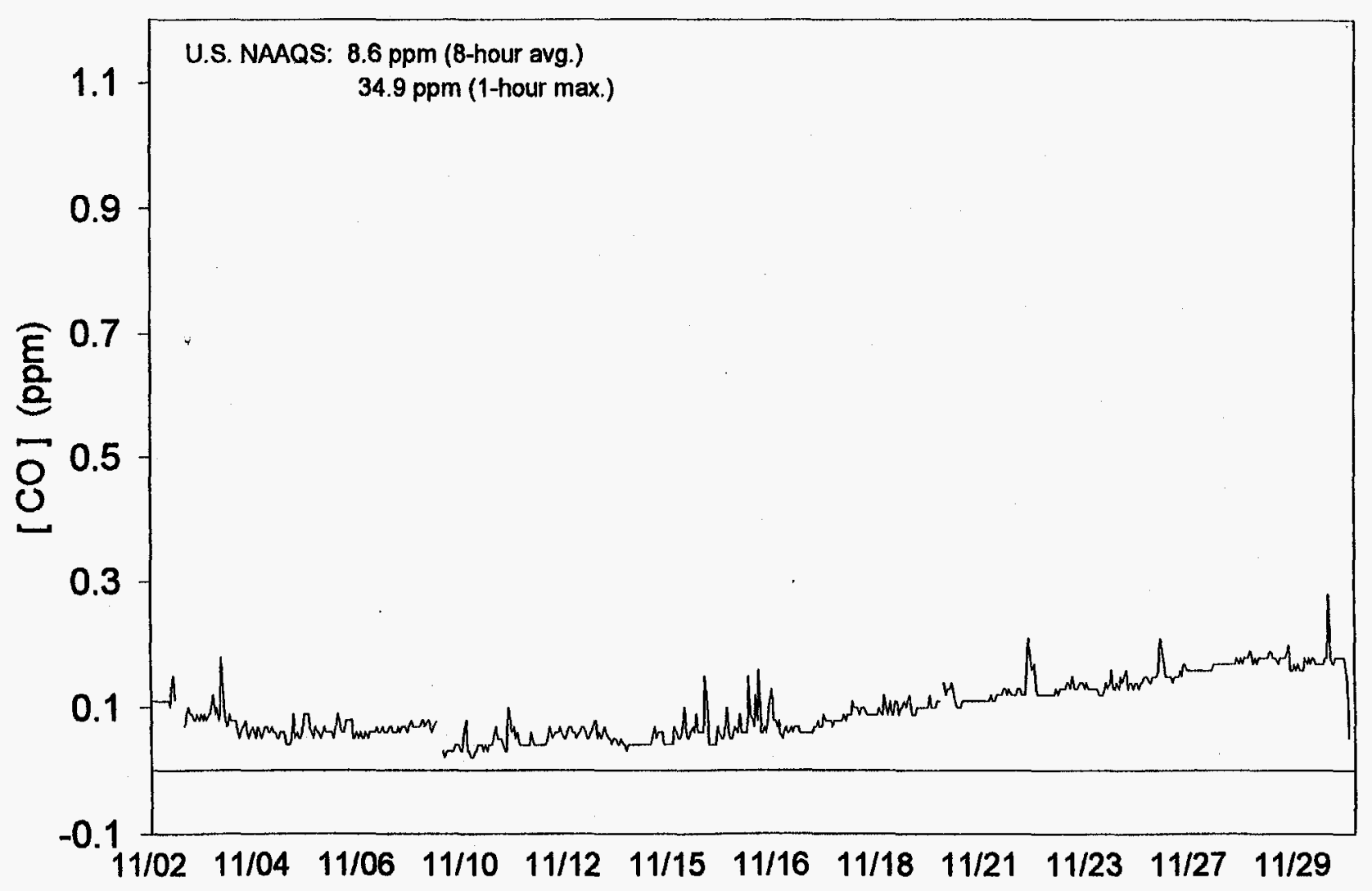




\section{Hut Point Hourly Average CO Levels}

December 1993

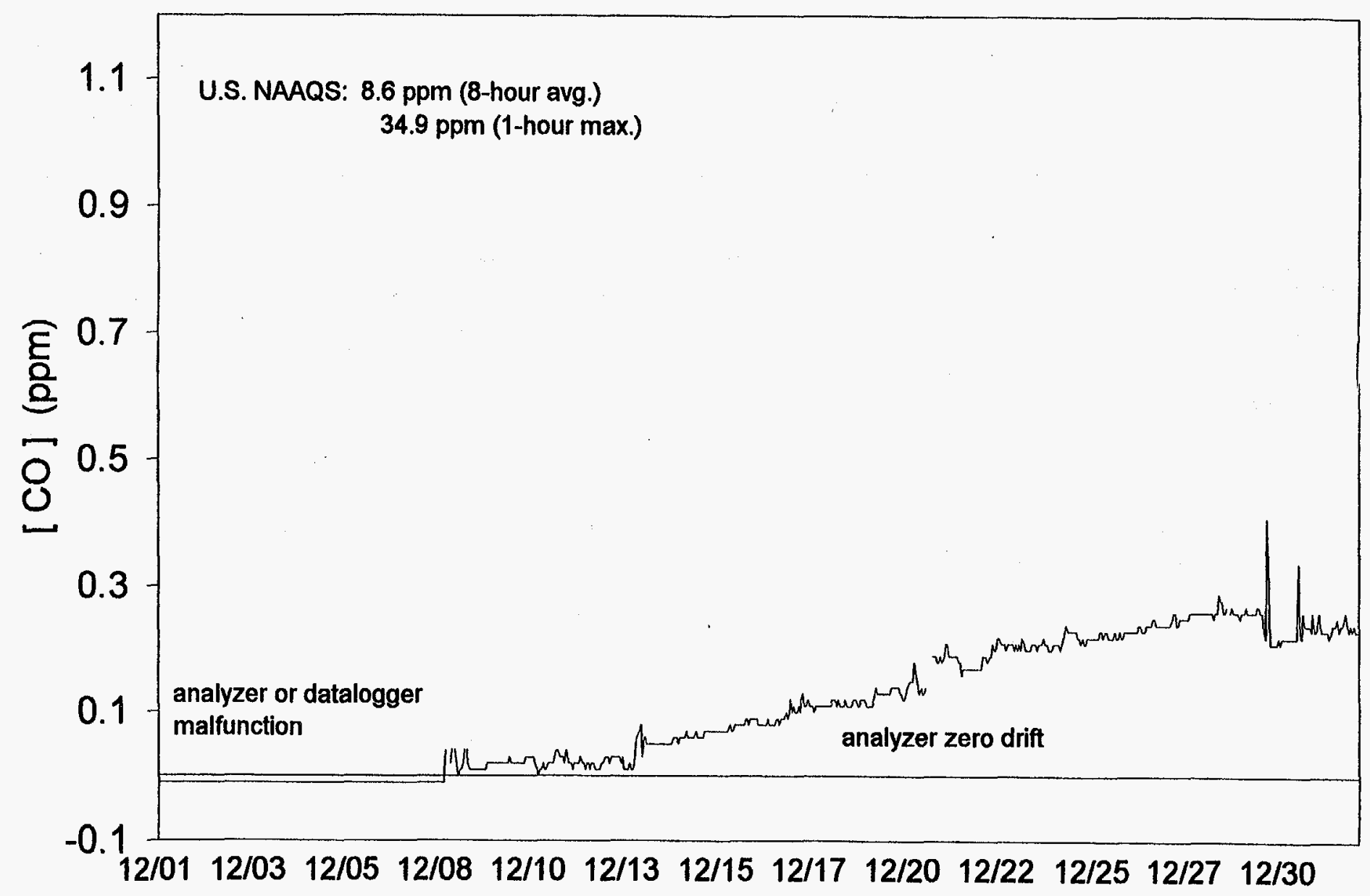




\section{Hut Point Hourly Average CO Levels}

January 1994

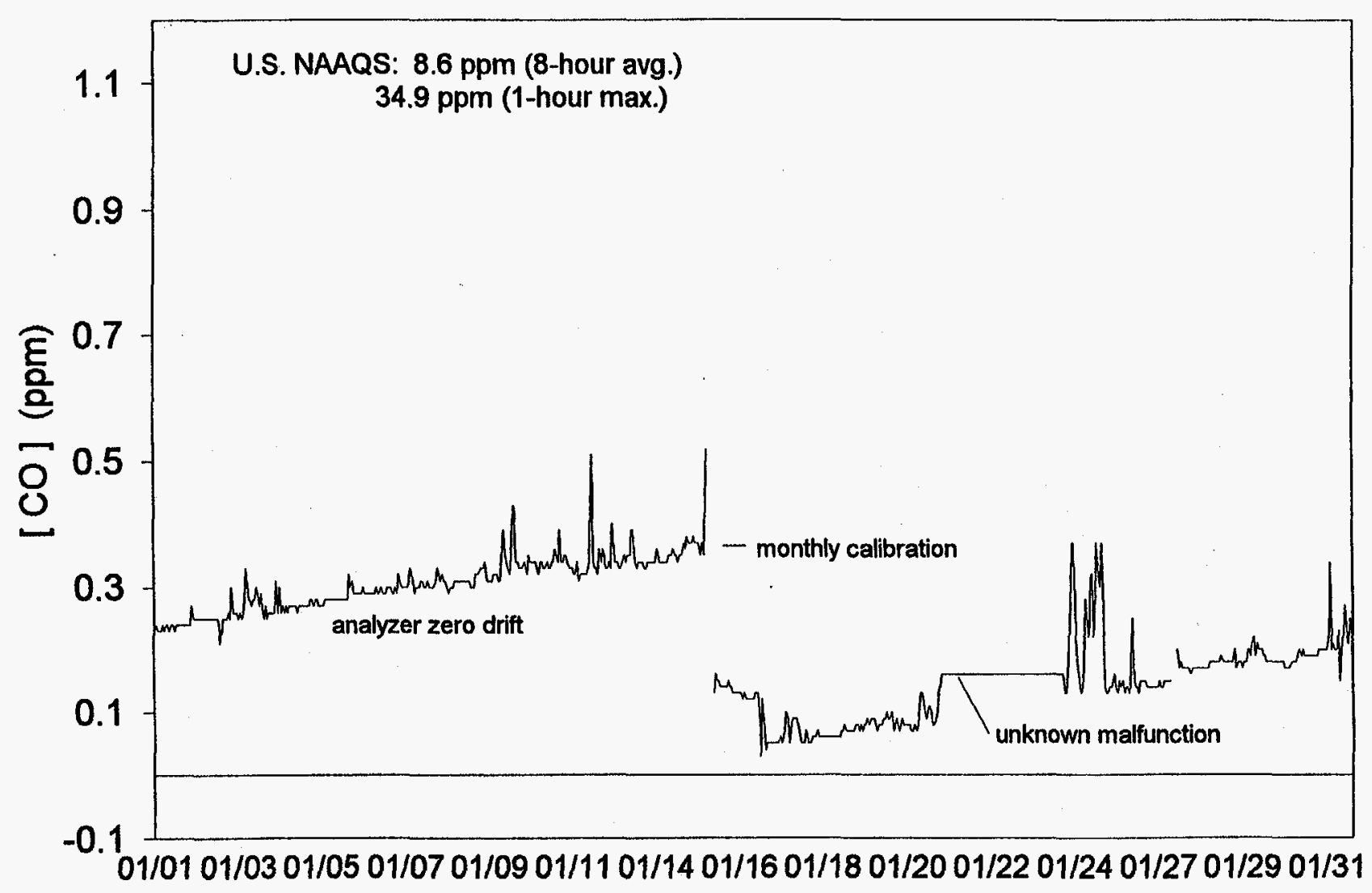




\section{Hut Point Hourly Average CO Levels}

February 1994

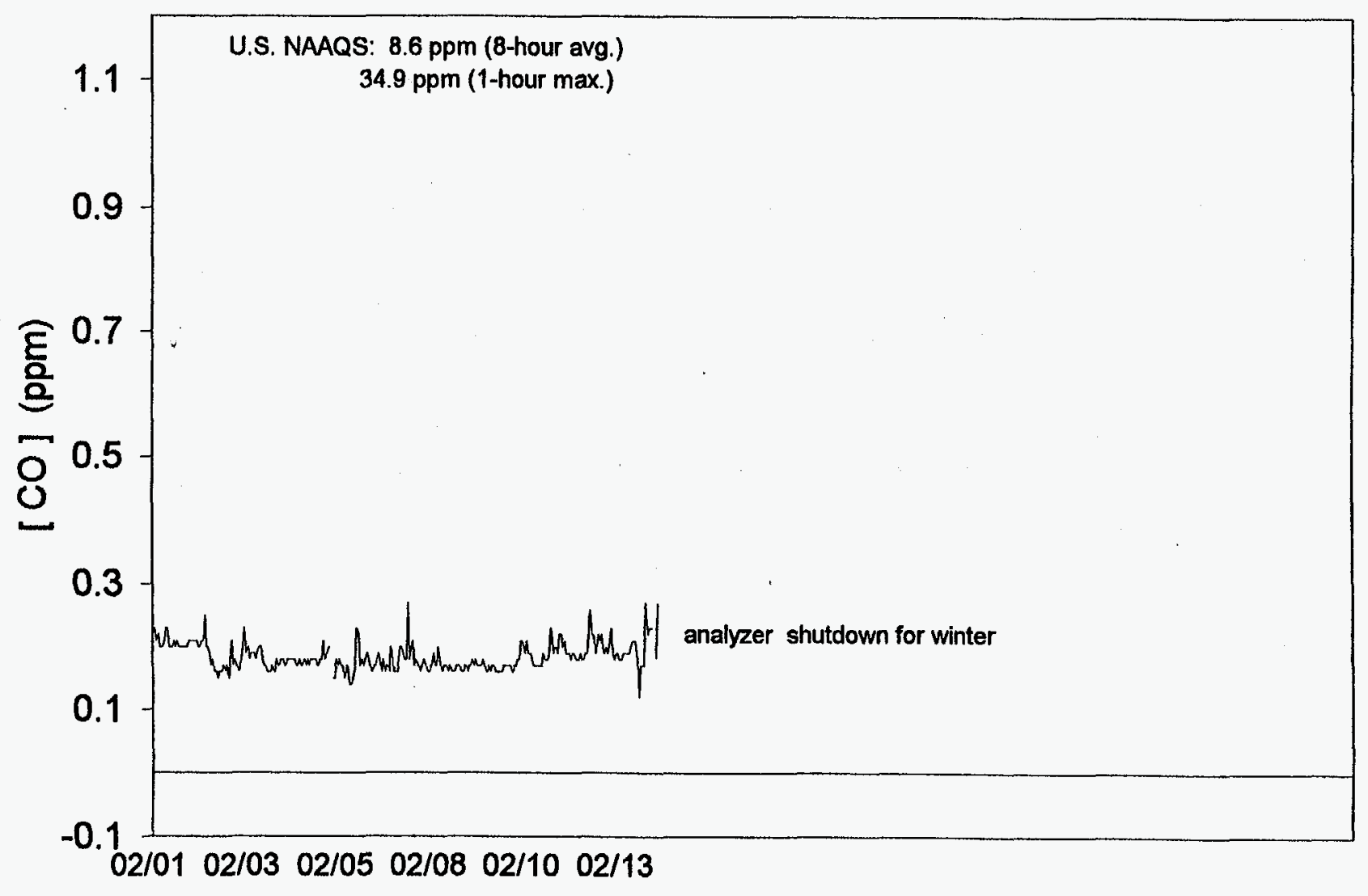




\section{Hut Point Hourly Average SO2 Levels}

November 1993

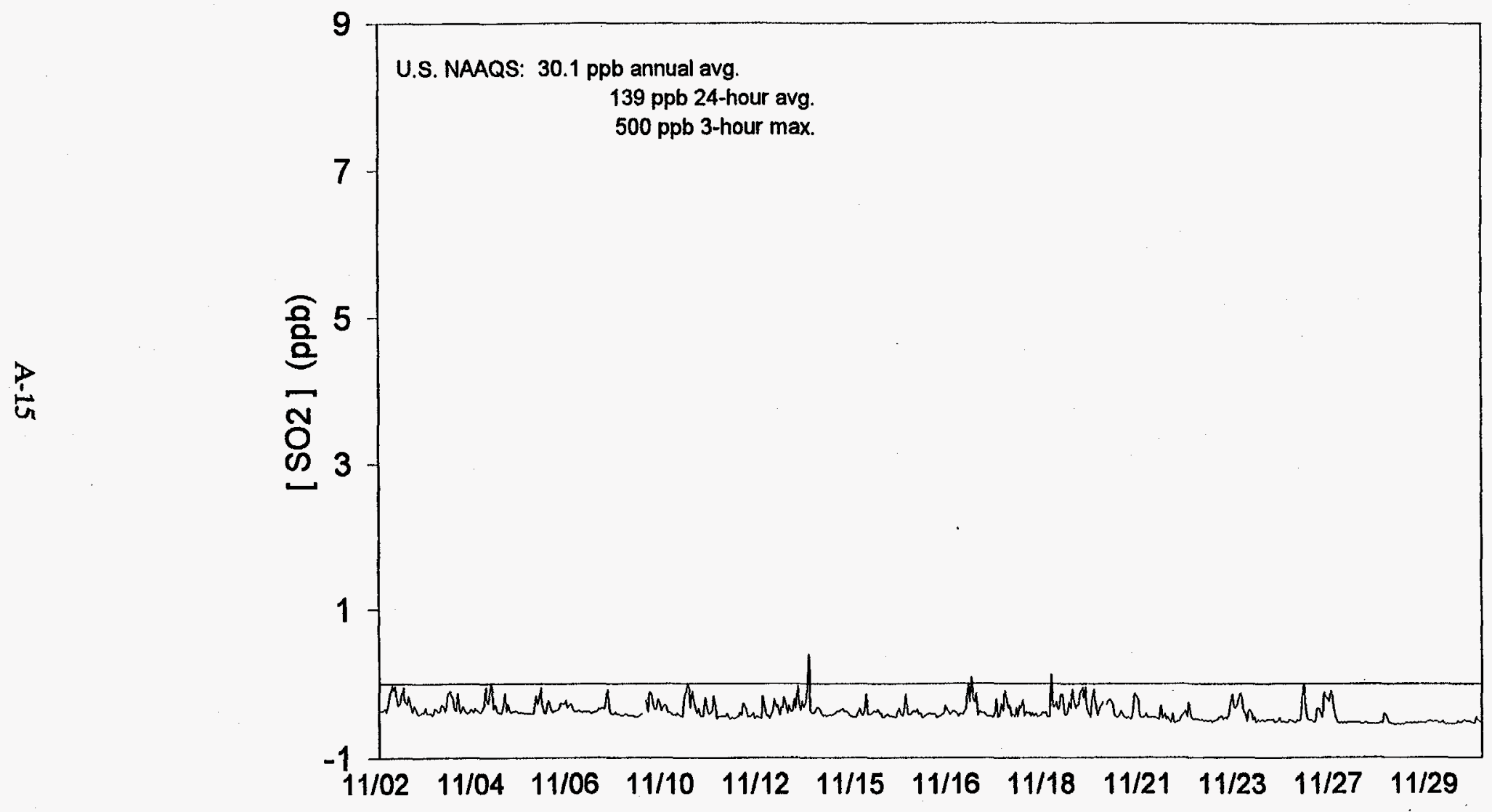




\section{Hut Point Hourly Average SO2 Levels}

December 1993

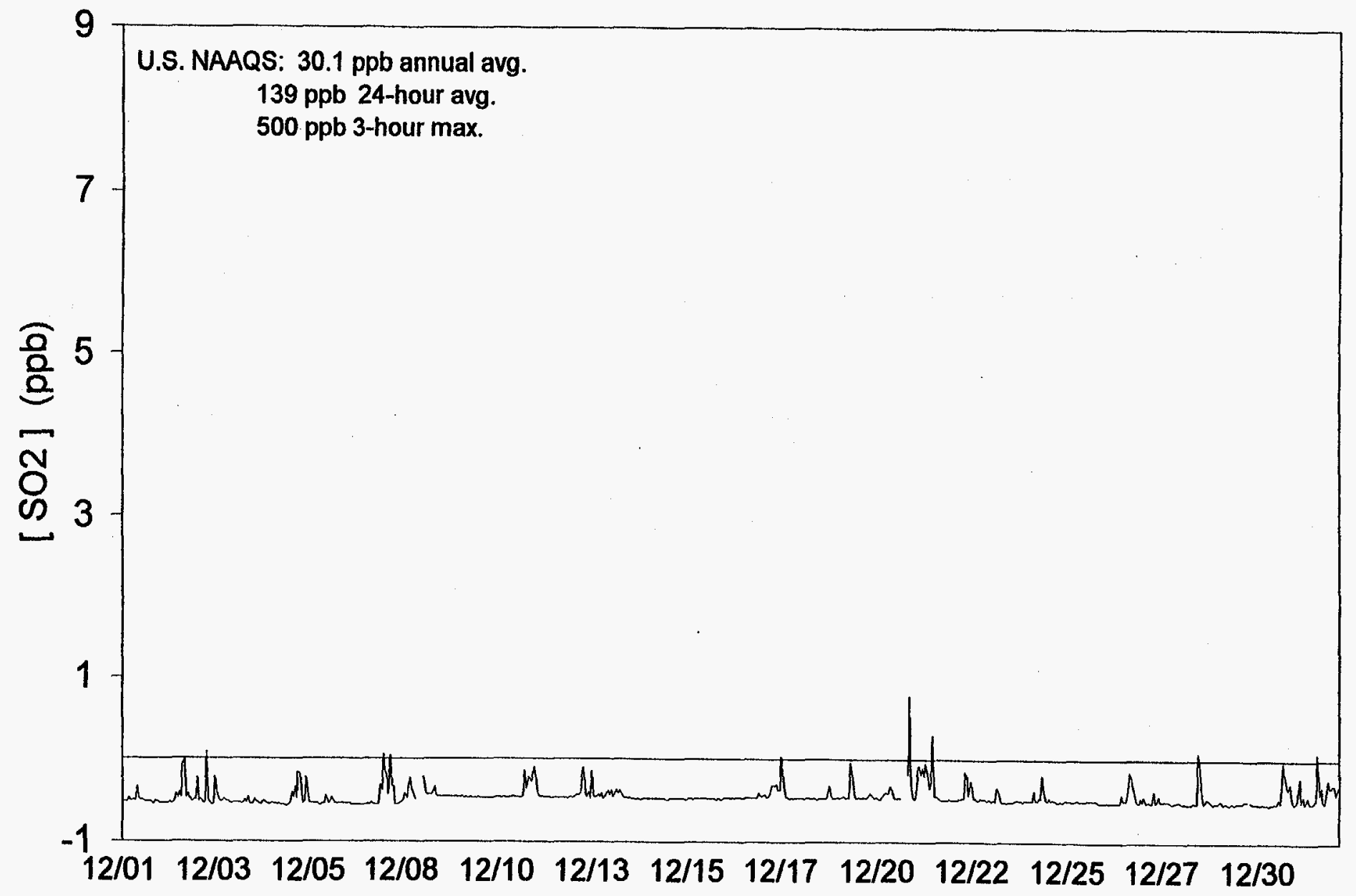




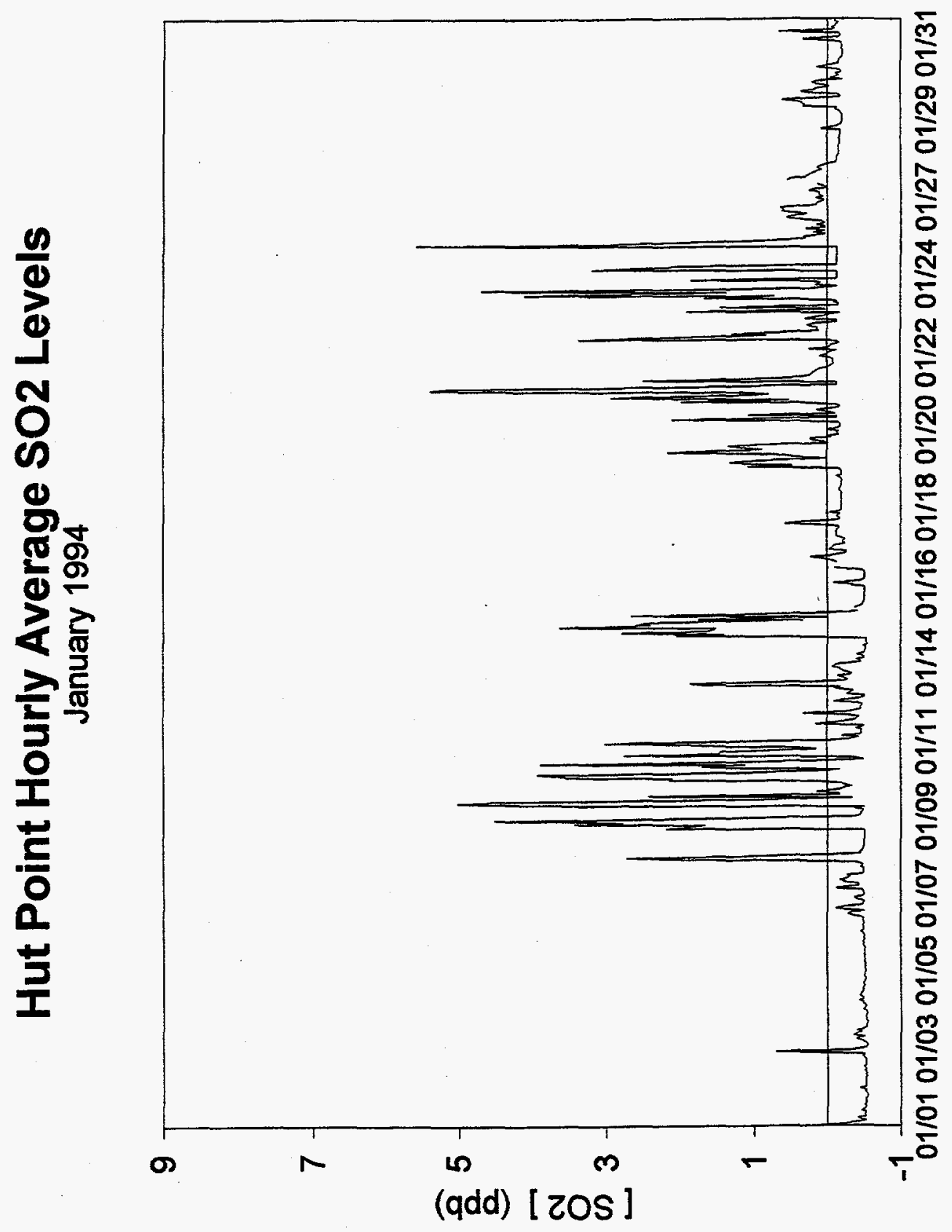




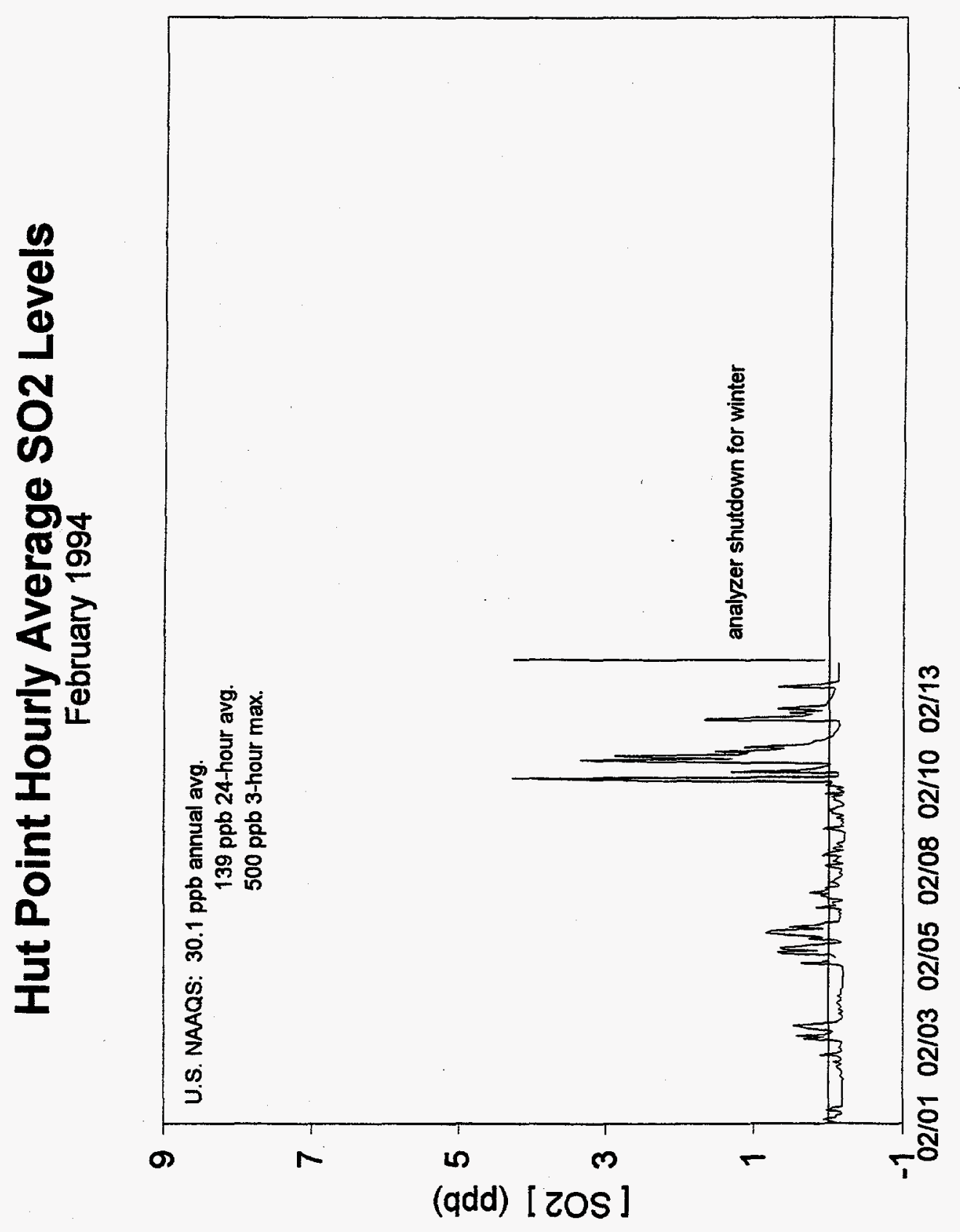


Hut Point Hourly Average NO Levels

November 1993

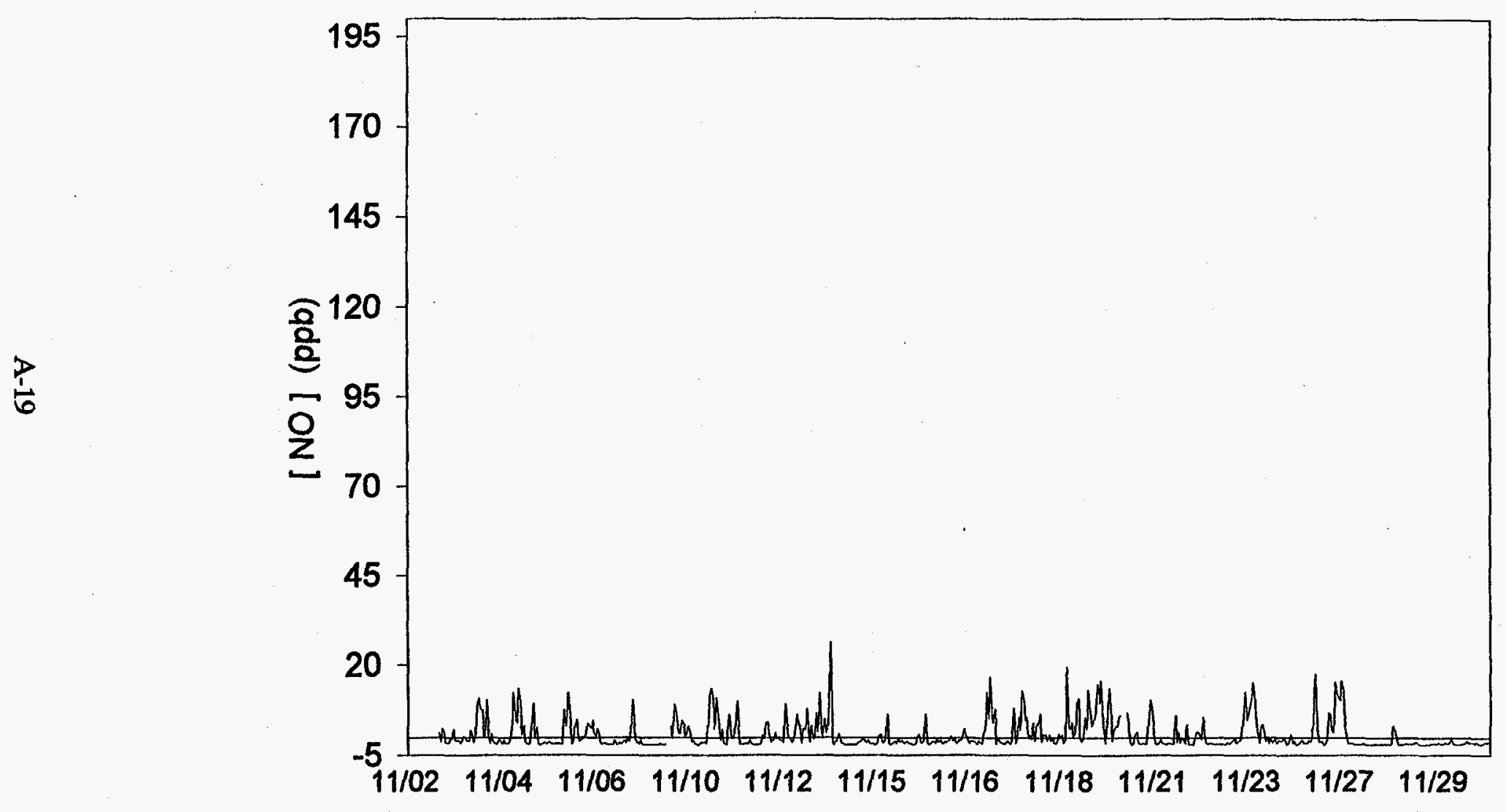




\section{Hut Point Hourly Average NO Levels}

December 1993

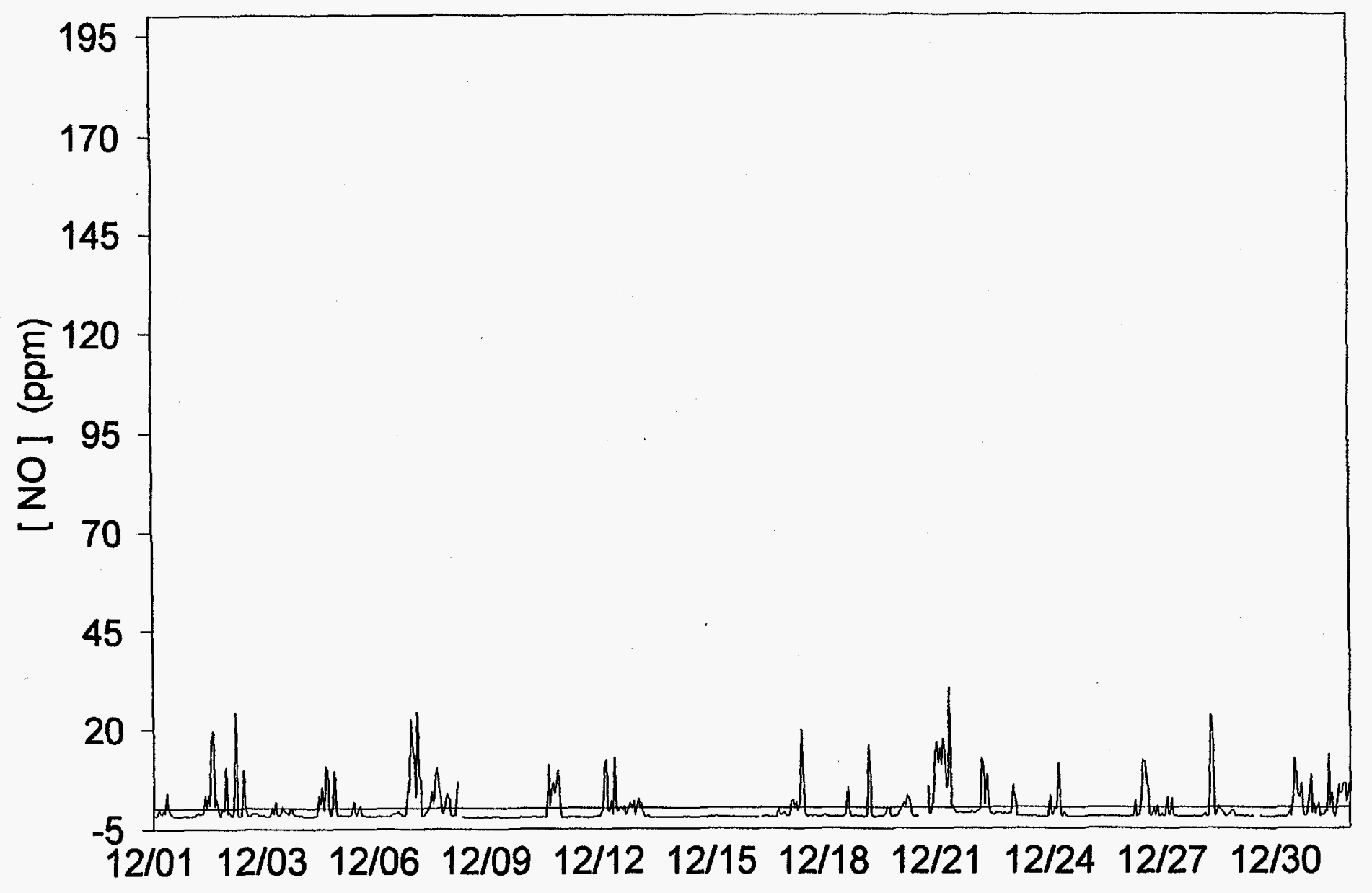




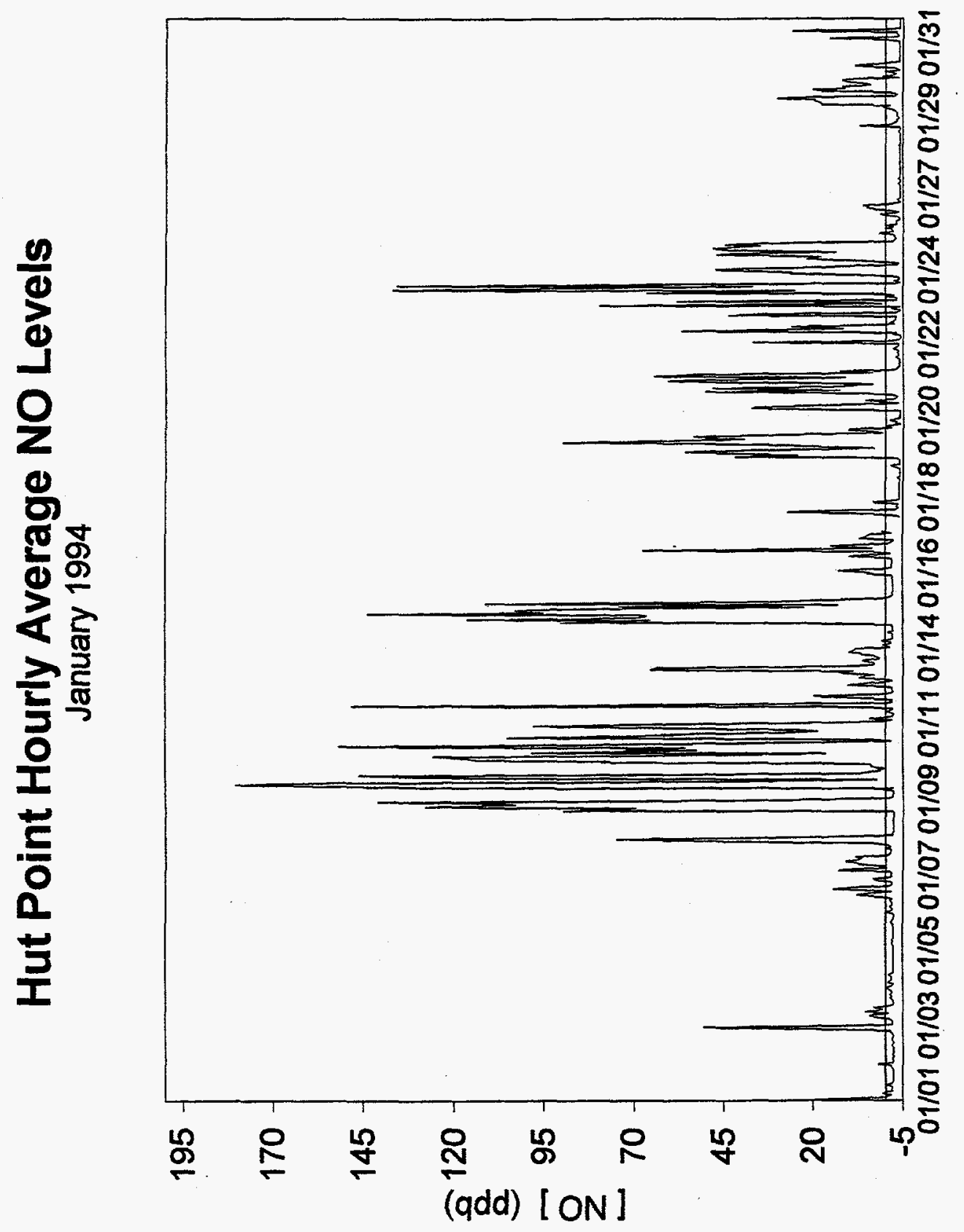




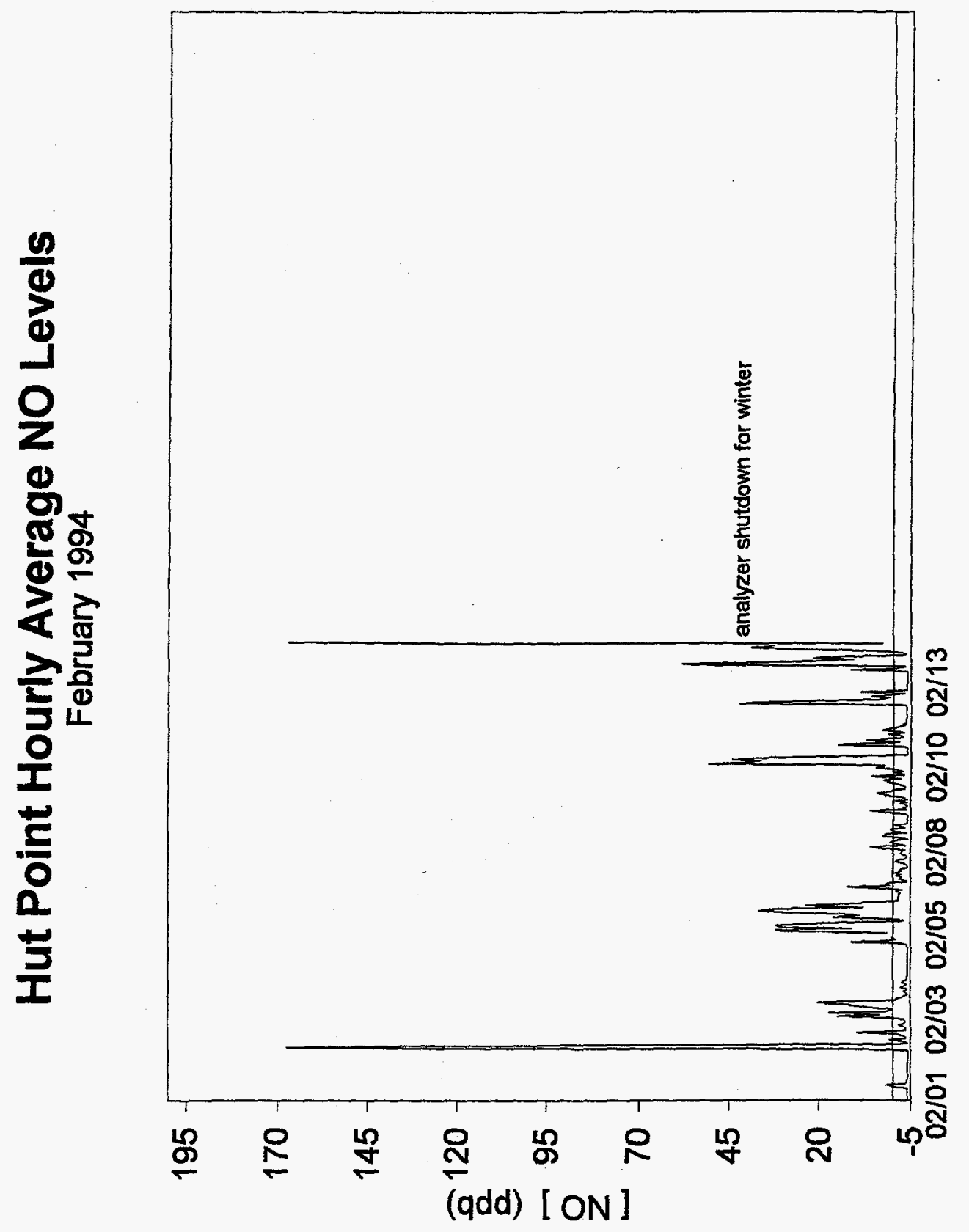




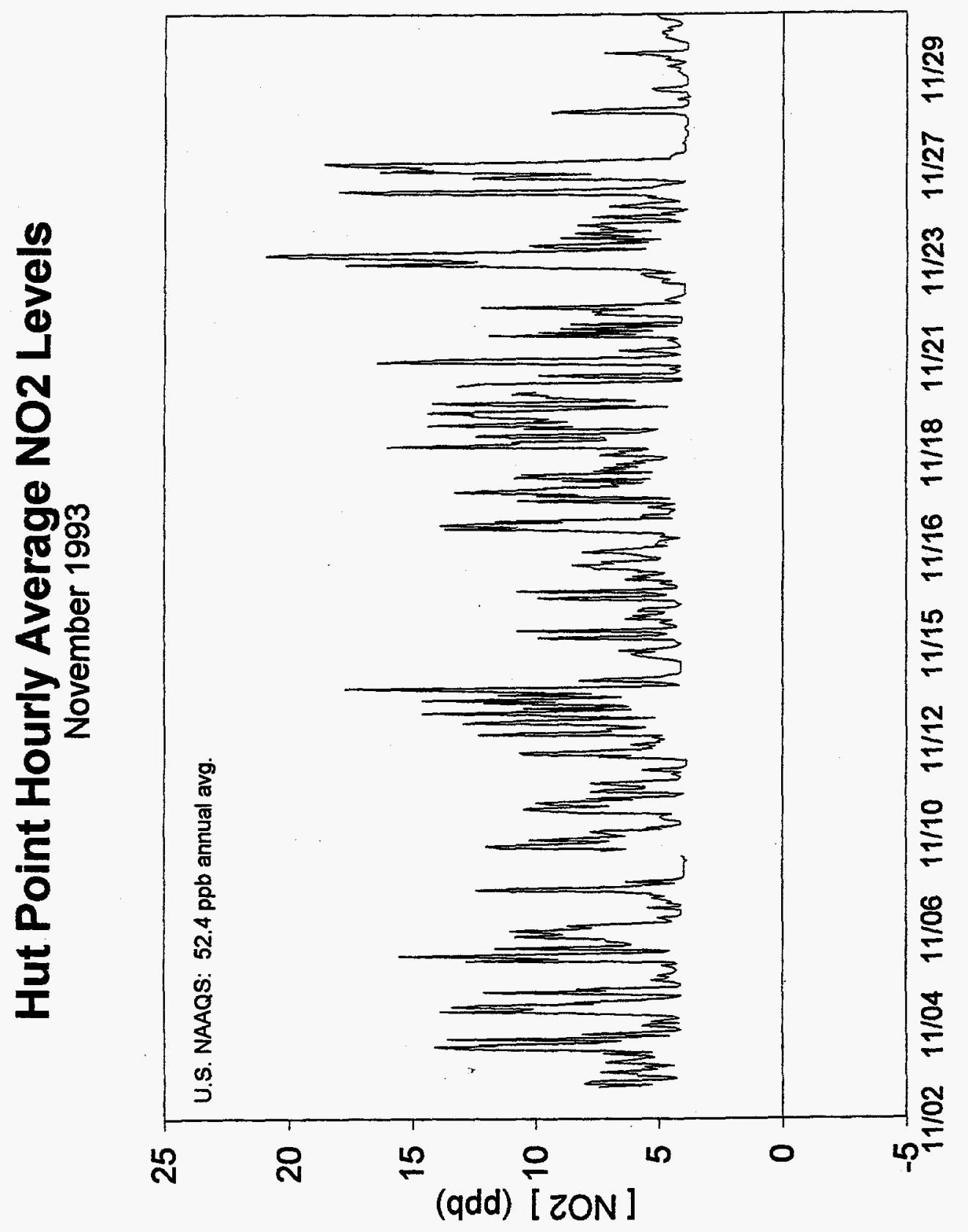




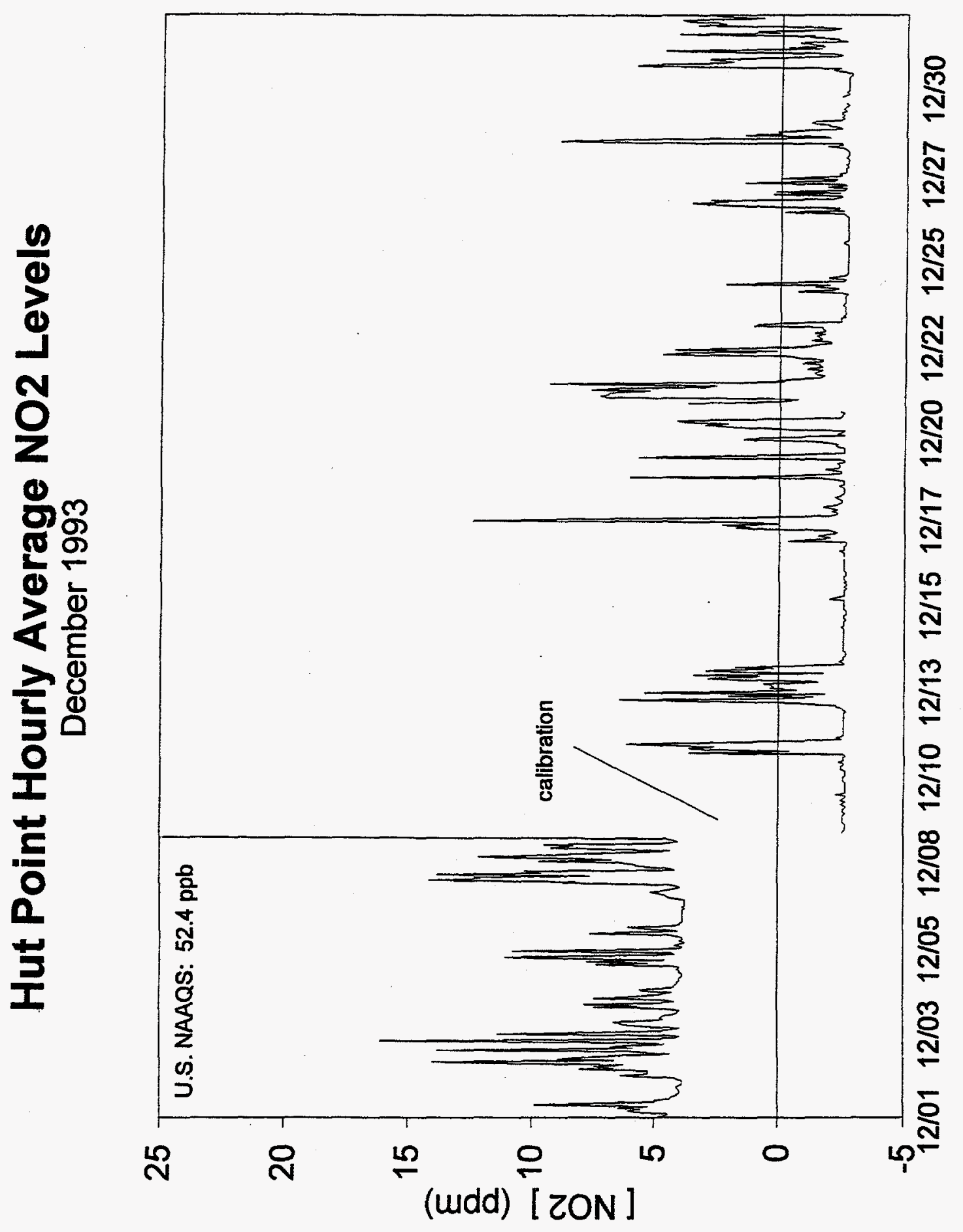




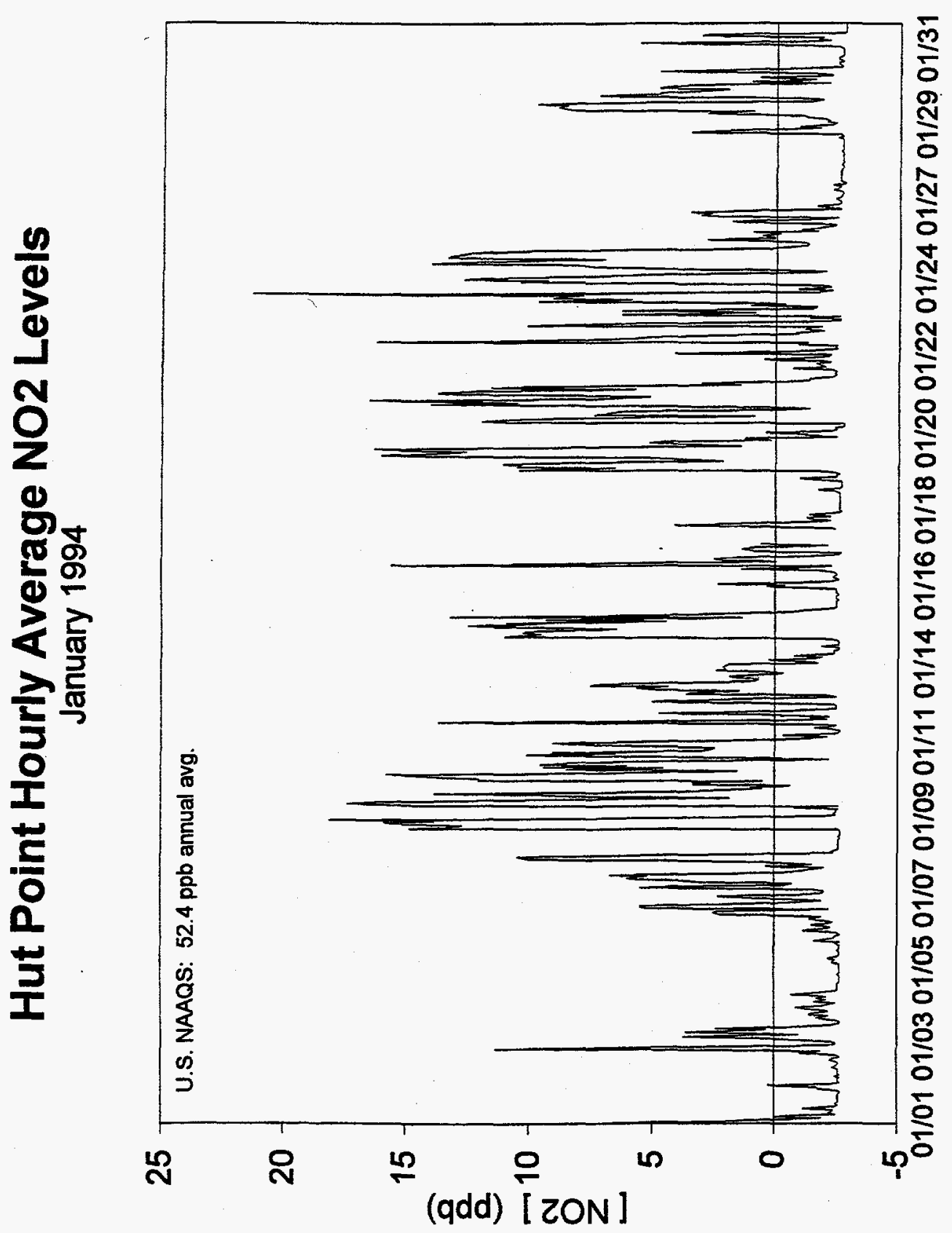




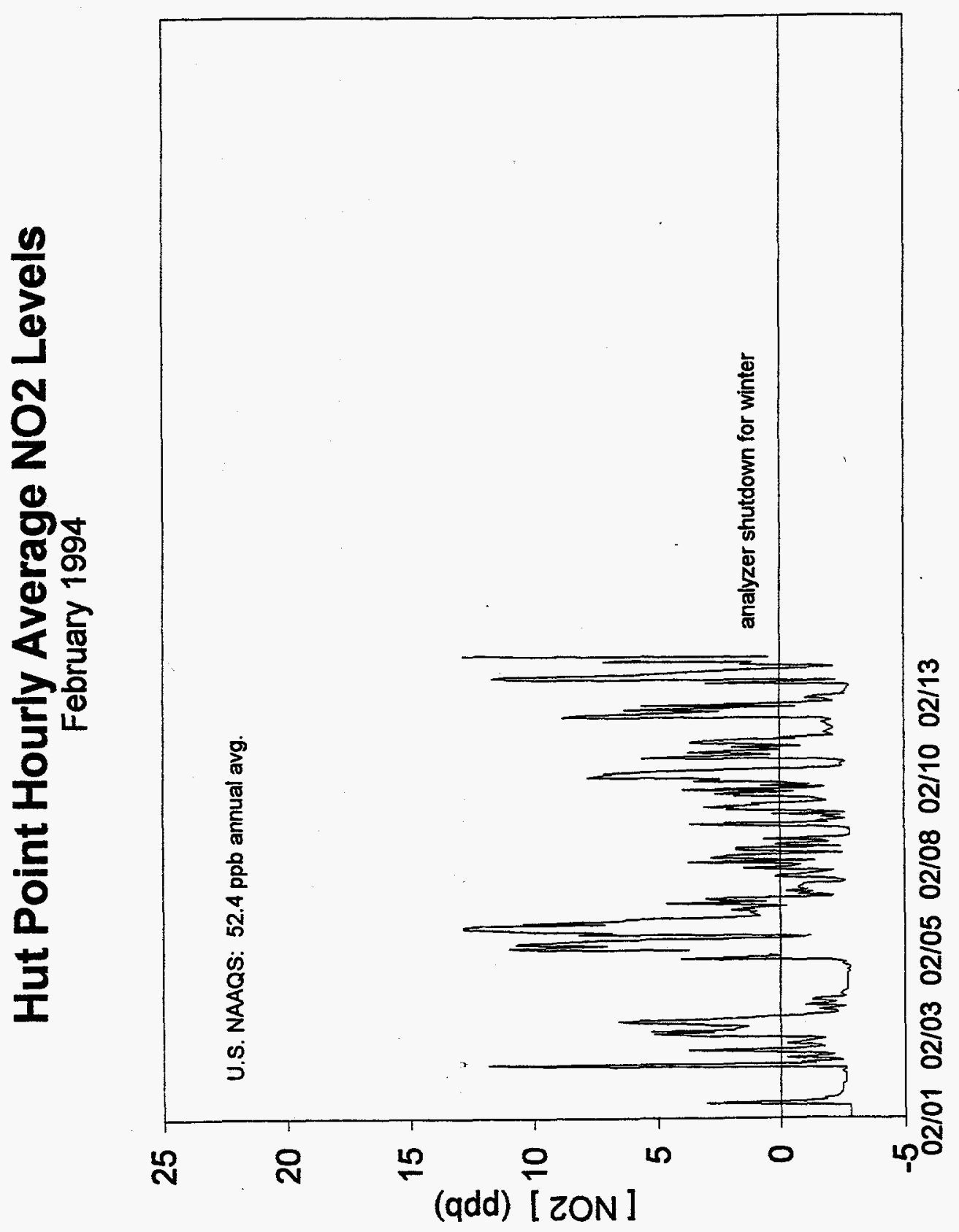




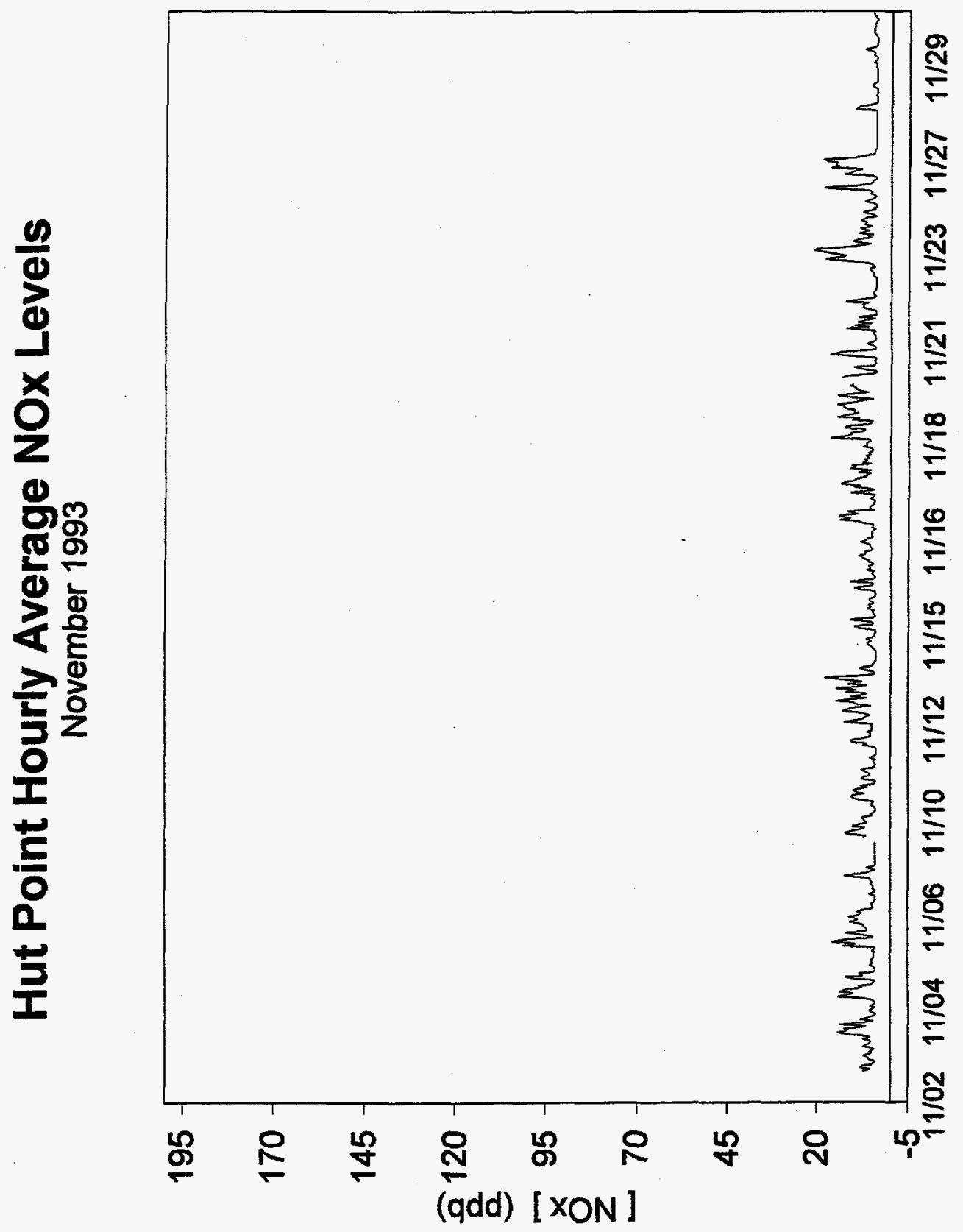




\section{Hut Point Hourly Average NOx Levels}

December 1993

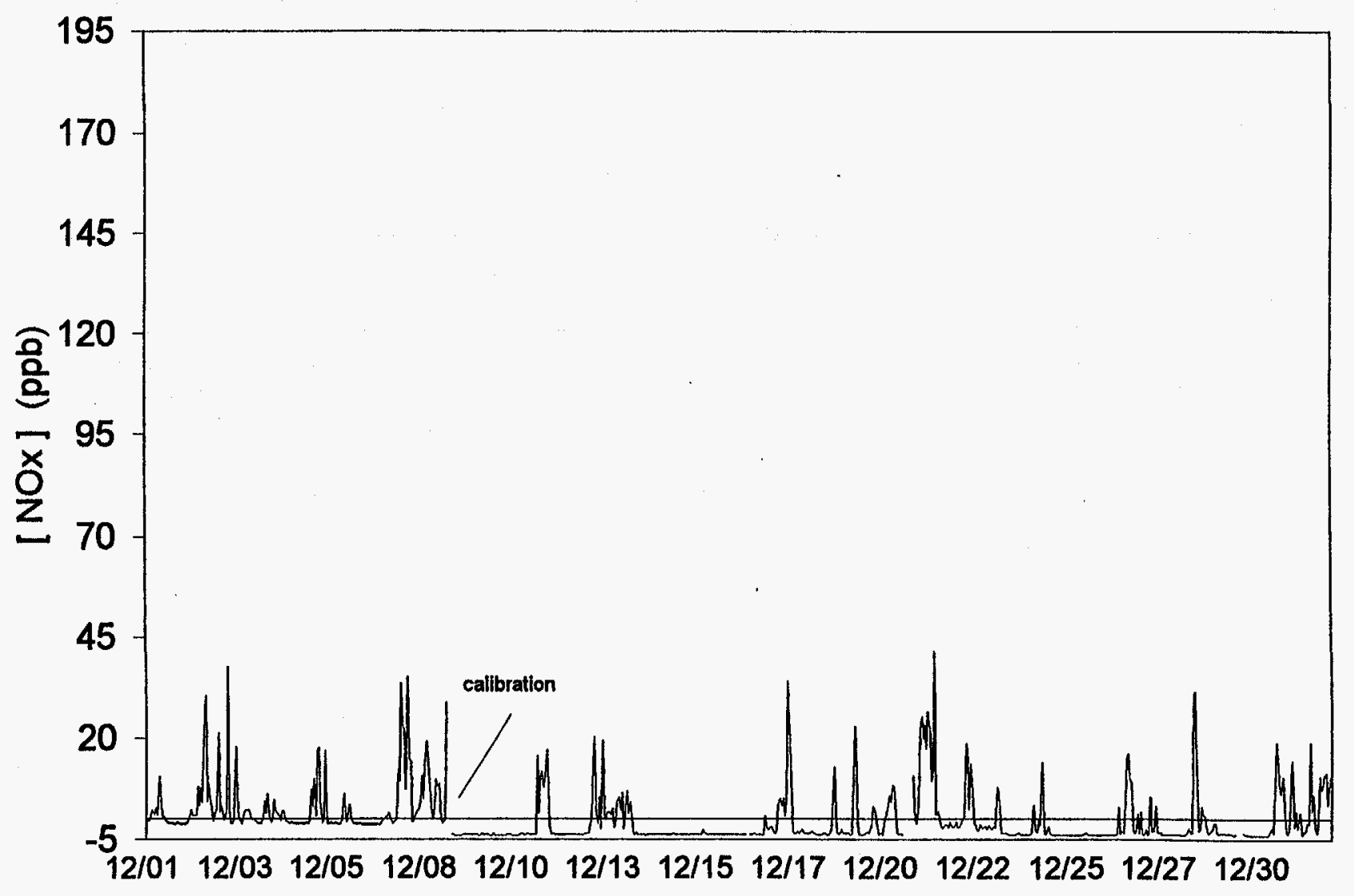




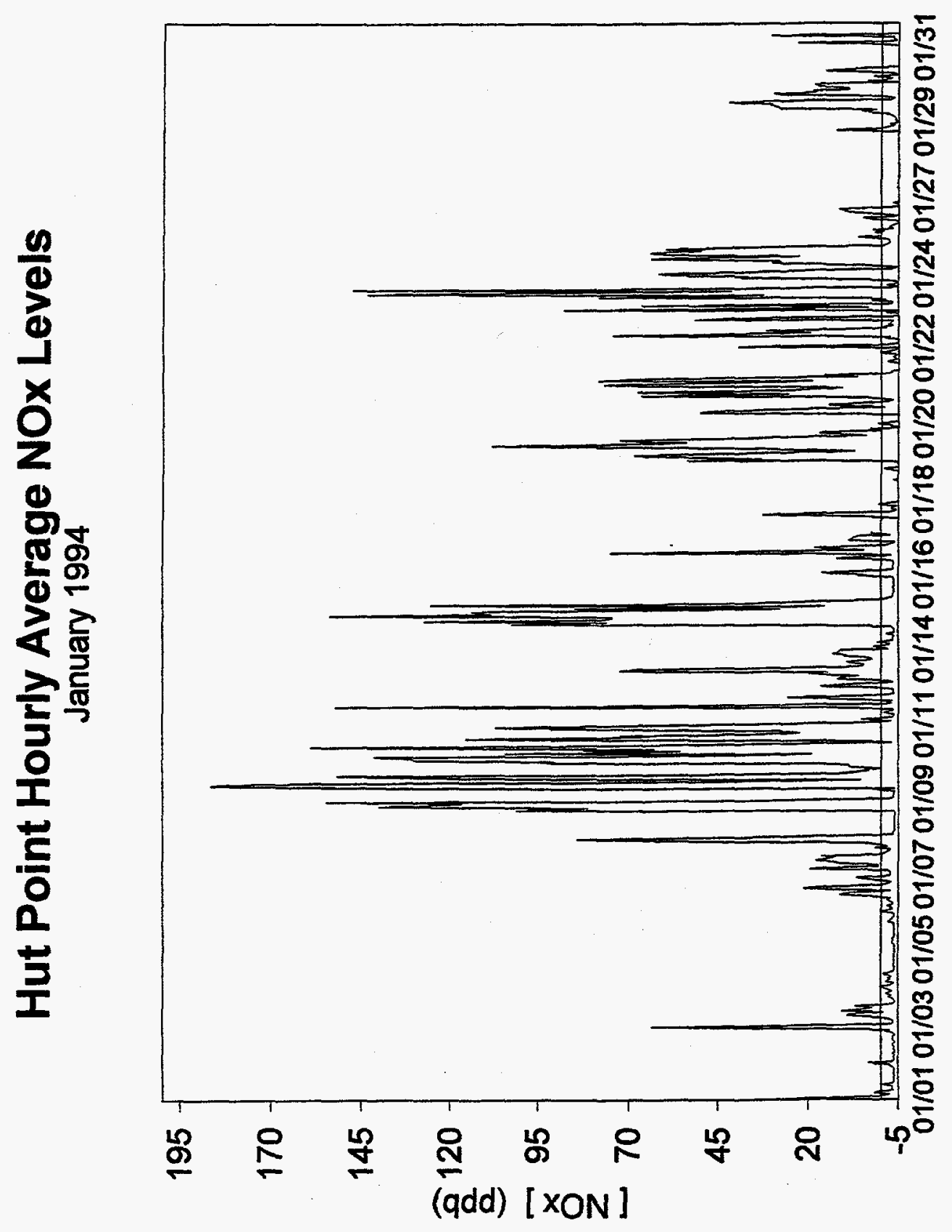




\section{Hut Point Hourly Average NOx Levels}

February 1994

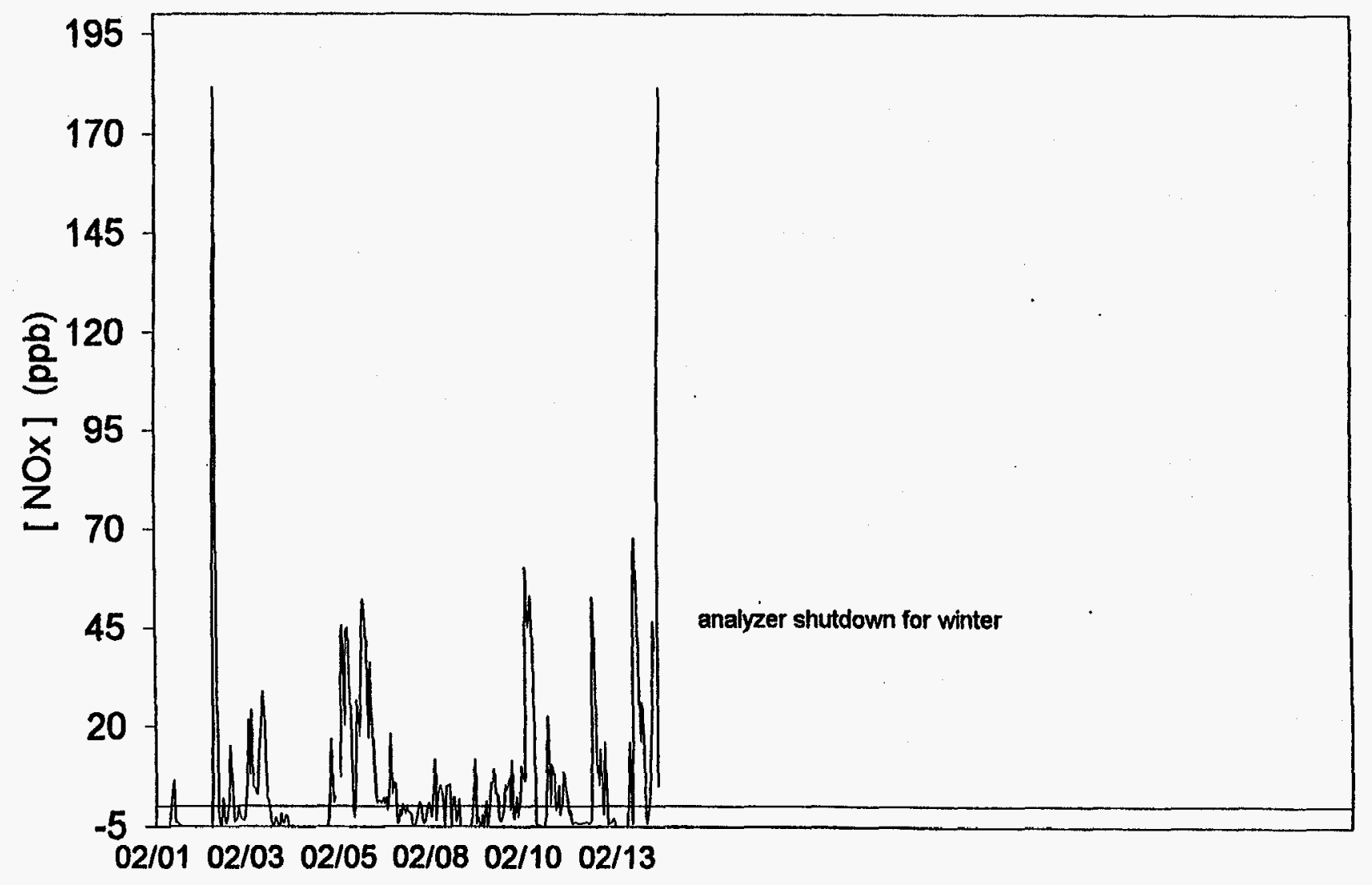

